Harvard Journal of Law \& Technology

Volume 14, Number 1 Fall 2000

\title{
A TheOry OF Claim InTERPRETATION
}

\author{
Craig Allen Nard
}

\section{TABLE OF CONTENTS}

I. IntRODUCTION $\ldots \ldots \ldots \ldots \ldots \ldots \ldots \ldots \ldots \ldots \ldots \ldots$

II. The Federal Circuit's Hypertextualism . . . . . . . . . . xxx

A. The Markman Revolution and the Beginning of

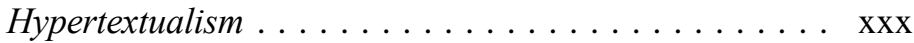

1. Markman I: PHOSITA Blinded ........... Xxx

2. Markman II and the Origins of the Pragmatic

Textualist Upheavel . . . . . . . . . . . . . xxx

a. "Internal Coherence" and the Role of

Extrinsic Evidence . . . . . . . . . . . xxx

b. Claim Interpretation as a "Mongrel

Practice" ................... $\mathrm{xxx}$

B. An Ideological Badinage in the Wake of

Markman II . . . . . . . . . . . . . . . . . Xxx

C. Ex Post Innovation Theories . . . . . . . . . . . . xxx

1. Improvement Theory

2. Design-Around Theory

III. Pragmatic Textualism: Through the Eyes of

THE ARTisan .................. Xxx

A. Extrinsic Context and the Role of Underlying

Assumptions ................... $\mathrm{xxx}$

B. Pragmatic Textualism and the Useful Arts . . . . . . . $\mathrm{xxx}$

1. The Centrality of the Artisan ...........

2. Claim Meaning and the Proper Allocation of

Interpretive Theory $\ldots \ldots \ldots \ldots \ldots \ldots \ldots \ldots x$

a. Institutional Competence ........... xxx

b. The Temporal Dimension and the Doctrine

of Equivalents .............

* Associate Professor of Law, Marquette University Law School. I would like to thank Thomas Cotter, Joseph Kearney, Mark Lemley, Clarisa Long, Michael McNulty, Robert Merges, Arti Rai, Peter Schanck, and Pol Valdevelde for their helpful comments and criticisms. I also wish to acknowledge the excellent research assistance of Lora Kaelber and Carlo Controne. 
c. Early Certainty, Uniformity, and Issue

Preclusion ............... $\mathrm{xxx}$

3. Choosing a Construction in the Face of

Persistent Ambiguity: Canons of Claim

Construction as Default Rules ........... xxx

IV. Conclusion $\ldots \ldots \ldots \ldots \ldots \ldots \ldots \ldots \ldots \ldots \ldots \ldots \ldots$

\section{INTRODUCTION}

Scholarly interest in theories of interpretation has increased dramatically over the last 15 to 20 years, ${ }^{1}$ resulting in myriad scholarly publications. ${ }^{2}$ Interpretive theory is germane to almost all areas of the law, including patent law, a subject in which I have a particular interest. My interest, however, as reflected in this article is not in how courts interpret the patent code, although that is a subject worthy of

1. This renascence is due largely to the schools of interpretation known as textualism and pragmatism. The influence of textualism is a result of the advocacy of some of its more prominent devotees; see, e.g., ANTONin SCALIA, A MATter OF INTERPRETATION: FEDERAL COURTS AND THE LAW (1997); Frank H. Easterbrook, The Role of Original Intent in Statutory Construction, 11 HARV. J.L. \& PUB. POL'Y 59 (1988). The greatly increased role of pragmatism, or what some refer to as practical reason, is largely attributable to several notable contemporary legal scholars and their writings; see, e.g., Richard A. Posner, Overcoming Law (1995), William N. Eskridge, JR., Dynamic Statutory interpretation (1994), Richard Rorty, Consequences of Pragmatism (1982), Cornel West, The American Evasion of Philosophy (1989), Thomas C. Grey, What Good is Legal Pragmatism?, in Pragmatism in LaW and Society 9 (Michael Brint \& William Weaver, eds., 1991). Of course, other interpretive theories have played a role as well, including deconstructionism, semiotics, and post-modernism.

2. See, e.g., EsKRIDGE, supra note 1; Bernard W. Bell, Legislative History Without Legislative Intent: The Public Justification Approach to Statutory Interpretation, 60 Оніо Sт. L.J. 1 (1999); John F. Manning, Textualism as a Nondelegation Doctrine, 97 Colum. L. Rev. 673 (1997); Carlos E. Gonzalez, Reinterpreting Statutory Interpretation, 74 N.C. L. REv. 585 (1996); Jane S. Schacter, Metademocracy: The Changing Structure of Legitimacy in Statutory Interpretation, 108 HARV. L. REV. 593 (1995); Philip P. Frickey, From the Big Sleep to the Big Heat: The Revival of Theory in Statutory Interpretation, 77 MINN. L. Rev. 241 (1992); Peter C. Schanck, Understanding Postmodern Thought and its Implications for Statutory Interpretation, 65 S. CAL. L. REV. 2505 (1992); John A. Ferejohn \& Barry R. Weingast, Limitation of Statutes: Strategic Statutory Interpretation, 80 Geo. L.J. 565 (1992); William N. Eskridge, Jr. \& Philip P. Frickey, Statutory Interpretation as Practical Reasoning, 42 StAn. L. Rev. 321 (1990); Daniel A. Farber, Statutory Interpretation and Legislative Supremacy, 78 GEO. L.J. 281 (1989). 
exploration. Rather, my concern relates to what interpretive theories courts, particularly the United States Court of Appeals for the Federal Circuit, employ when interpreting patent claims. ${ }^{3}$

The relationship between theories of interpretation (e.g., statutory or contract) and claim interpretation is important for at least three reasons. First, some judges on the Federal Circuit have analogized claim interpretation to statutory interpretation, while others have compared it to interpreting a contract; ${ }^{4}$ and, therefore, studying theories of interpretation can inform our understanding of how the court interprets patent claims. Second, in the words of one of the founding fathers of modern patent law, "the name of the game is the claim." That is, the patent claim defines the proprietary boundaries of the invention, ${ }^{6}$ and determining where exactly these boundaries reside is often dispositive of such crucial issues as patent validity and infringement. ${ }^{7}$ Lastly, and perhaps most importantly, the manner in

3. I use the word "interpretation" here to mean the process by which courts discern the meaning of claim language. Later in the article, I use "interpretation" to mean the existence of a choice between or among competing constructions. See infra text accompanying notes $280-89$.

4. See Markman v. Westview Instruments, Inc., 52 F.3d 967, 985-87 (Fed. Cir. 1995) (discussing the similarities between statutory interpretation and claim interpretation). In Markman, Judge Mayer asserted that patents are more analogous to contracts. See id. at 997. Indeed, the statutory analogy is arguably misplaced. See, e.g., John R. Thomas, On Preparatory Texts and Proprietary Technologies: The Place of Prosecution Histories in Patent Claim Interpretation, 47 UCLA L. Rev. 183, 210 (1999) ("[T]he reality is that patents are not statutes, but unique legal instruments that are the product of a statute. An analysis that attended more closely to the needs of the technological community would have treated patents as they are, rather than as poor relations of more mainstream legal instruments.").

5. Giles S. Rich, Extent of the Protection and Interpretation of Claims - American Perspectives, 21 INT'L REV. INDUS. PROP. \& COPYRIGHT L. 497, 499 (1990).

6. See 35 U.S.C. $\$ 112$ (1994), If 2 (requiring the patent applicant to include in his application "one or more claims particularly pointing out and distinctly claiming the subject matter which the applicant regards as his invention"). See also Zenith Lab., Inc. v. Bristol-Myers Squibb Co., 19 F.3d 1418, 1424 (Fed. Cir. 1994) ("It is the claim that sets the metes and bounds of the invention entitled to the protection of the patent system."); Corning Glass Works v. Sumitomo Elec. U.S.A., Inc., 868 F.2d 1251, 1257 (Fed. Cir. 1989) ("A claim in a patent provides the metes and bounds of the right which the patent confers on the patentee to exclude others from making, using or selling the protected invention.").

7. See, e.g., Markman, 52 F.3d at 989 (Mayer, J.,concurring) ("[T]o decide what the claims mean is nearly always to decide the case."); Lucas Aerospace, Ltd. v. Unison Indus., L.P., 890 F. Supp. 329, 332 n.3 (D. Del. 1995) ("[C]laim construction more often than not determines the outcome on infringement."); Elf Atochem N. Am., Inc. v. Libbey-Owens-Ford Co., 894 F. Supp. 844, 859 (D. Del. 1995) ("Not surprisingly, resolution of the claim interpretation issues often resolves the infringement issue, as it 
which the Federal Circuit interprets patent claims reflects the court's view of the proper scope of judicial power, which has implications for patent law's delicate incentive dynamic.

My goal in this article is to explore the proper scope of judicial power in patent law by focusing on the Federal Circuit's theories of claim interpretation. Specifically, I examined the court's claim interpretation jurisprudence in an attempt to discern whether there is a predominant interpretive school and whether this school is in accord with the patent code and post-patent innovation practice or what can be characterized as "improvement-theory" and "design-around theory." These two theories are concerned with the incentives for persons of ordinary skill in the art, namely competitors of the patent owner, ${ }^{9}$ to improve upon or design around the patented technology. ${ }^{10}$ Closely related to the relationship between interpretive theory and postinnovation practice are the proper roles of the doctrine of equivalents ${ }^{11}$ and optimal claim scope. Indeed, the interpretive tools used by a court directly affect the extent of the patentee's property interest, and, therefore, where the patentee's competitors may and may not tread. Thus, claim interpretation theory lies at the heart of our patent system.

will in this case."); MCV, Inc. v. King-Seeley Thermos Co., 870 F.2d 1568, 1570 (Fed. Cir. 1989) ("[T]he dispositive issue on the merits would be the definition of the invention."); Linda Greenhouse, Ruling Curbs Jury's Role on Patents, N.Y. Times, Apr. 24, 1996, at D1("Once you have construed the scope of the claim, that's the end of the game.”) (quoting patent attorney, Bo Pasternack of Choate, Hall \& Stewart).

8. See infra text accompanying notes $168-94$.

9. See Hoganas AB v. Dresser Indus., Inc., 9 F.3d 948, 952 n.15 (Fed. Cir. 1993) (reasoning that a competitor of a patentee is analytically equivalent to the person of ordinary skill in the art).

10. It would be difficult to overstate the importance of patent law's disclosure requirements, which are contained in the first two paragraphs of 35 U.S.C. $§ 112$ (1994). Section 112 requires a patent applicant to set forth his invention so as to enable other artisans to make and use the claimed invention. A principal function of the disclosure requirements is to provide other artisans in the technical field with information that enlarges the storehouse of knowledge, and therefore spur these artisans to improve upon or design around the claimed invention - thus leading to further technological progress.

11. The doctrine of equivalents ("DOE") permits courts to find infringement when an accused infringing device is an "equivalent" to that claimed in the patent. This doctrine understands that a strict and literal adherence to the written claim in determining scope of protection can invite unfair subversion of a valuable right, which would substantially diminish the economic value of patents. As the Supreme Court noted, "courts have also recognized that to permit imitation of a patented invention which does not copy every literal detail would be to convert the protection of the patent grant into a hollow and useless thing." Graver Tank \& Mfg. Co. v. Linde Air Products Co., 339 U.S. 605, 607 (1950). See infra text accompanying notes 295-309. 
A study of the Federal Circuit's claim interpretation jurisprudence reveals two schools of interpretation. I characterize these approaches as (1) hypertextualism, ${ }^{12}$ which is the predominant interpretative theory; and (2) pragmatic textualism, ${ }^{13}$ which is gradually asserting itself. The hypertextualist judge has an expansive view of judicial power, characterizing claim interpretation as a question of law subject to de novo review. This highly formalistic approach stresses textual fidelity and internal textual coherence, ${ }^{14}$ but eschews extrinsic evidence as an interpretive tool, portraying its use as "rarely, if ever," proper. ${ }^{15}$ Although hypertextualism posits that expert testimony may be used if the intrinsic record ${ }^{16}$ is ambiguous, a hypertextualist judge rarely finds ambiguity. If ambiguity is found, expert testimony may be used to

12. I am not the first to use the term "hypertextualism" in the context of interpretive theory. See, e.g., 2 Bruce Ackerman, We the People: Transformations 72 (1998); Richard J. Pierce, Jr., The Supreme Court's New Hypertextualism: An Invitation to Cacophony and Incoherence in the Administrative State, 95 Colum. L. Rev. 749 (1995).

13. I should note at this point that I am well aware of the many criticisms of textualism as a "plain meaning" or "four corners" approach to interpretation. See infra note 197. Although this criticism may arguably prove to be true of textualism as applied in practice, I adopt in this article a form of textualism that, while faithful to the text, understands the importance of extrinsic context in discerning meaning. See infra text accompanying notes 195-234. To a large extent, my theory of "pragmatic textualism" has been influenced by the philosophy of pragmatism and the interpretive school of thought known as textualism as set forth by Judges Richard Posner and Frank Easterbrook, respectively. Judge Posner, building upon the rich history of pragmatism dating back to John Dewey and William James, has stressed the need for pragmatism as an "antidote for formalism" and the connectedness between knowledge and empiricism. See generally, Posner, supra note 1. See also, John Dewey, THE QueSt FOR Certainty (Capricorn Books 1960) (1929); W illiam James, Pragmatism (World Publishing Co. 1961). I am receptive to the textualist philosophy of Judge Easterbrook because his view of textualism emphasizes the importance of linguistic conventions and social practices to discerning meaning. See, e.g., Frank H. Easterbrook, Text, History, and Structure in Statutory Interpretation, 17 HARV. J.L. \& PUB. POL'Y 61, 61 (1994) ("Words take their meaning from contexts, of which there are many - other words, social and linguistic conventions, the problems the authors were addressing.").

14. Judge Richard Posner would refer to this type of approach as "bottom-up reasoning," whereby one engages in "interpretation according to "plain meaning" and "starts with the words of the statute or other enactment, or with a case or mass of cases, and moves from there - but one doesn't move far." POSNER, supra note 1, at 172.

15. Vitronics Corp. v. Conceptronic, Inc., 90 F.3d 1576, 1585 (Fed. Cir. 1996).

16. The intrinsic record in claim interpretation includes the (1) patent claims; (2) a detailed explanation of the invention known as the specification, or more accurately, the written description; and (3) the prosecution history, which is a written record of the proceeding before the Patent and Trademark Office between a patent applicant and a patent examiner. 
educate the judge in the relevant technology - not for the purpose of interpreting the ambiguous claim language. ${ }^{17}$

On the other hand, the pragmatic textualist approach, while embracing the importance of textual fidelity and internal coherence, also emphasizes the relevance of extrinsic context and industry custom, of which patent law's "person having ordinary skill in the art" ("PHOSITA") ${ }^{18}$ is representative. This hypothetical artisan is one of the cynosures of our patent system and is valued by the pragmatic textualist as an interpretive tool because the artisan has knowledge of the underlying assumptions present in his technological community and is sensitive to the facts on the ground. ${ }^{19}$ Indeed, patents are written by and for persons having ordinary skill in the art, ${ }^{20}$ and to limit claim construction to the intrinsic record is, for the pragmatic textualist, a legal fiction largely detached from what Arthur Corbin referred to as the "undisputed contexts." 21 Because the meaning of a word cannot be "divorced from the circumstances in which it is used," 22 a pragmatic

17. See, e.g., EMI Group N.A., Inc. v. Intel Corp., 157 F.3d 887, 892 (Fed. Cir. 1998) ("The Federal Circuit has admonished that claims should preferably be interpreted without recourse to extrinsic evidence such as expert testimony, other than perhaps dictionaries or reference books, and that expert testimony should be received only for the purpose of educating the judge. See Markman, 52 F.3d at 983. . . In Cybor Corp. v. FAS Techs., Inc., 138 F.3d 1448, 1454, the court reaffirmed that extrinsic evidence including expert testimony is not to be relied upon for purposes of claim interpretation, other than to aid the judge in understanding the technology; such evidence is only 'an aid to the court in coming to a correct conclusion as to the true meaning of the language employed in the patent."').

18. See Cyril A. Soans, Some Absurd Presumptions in Patent Cases, 10 IDEA 433, 438 (1966) (referring to patent law's person having ordinary skill in the art by the acronym "Mr. Phosita").

19. See In re GPAC, Inc., 57 F.3d 1573, 1579 (Fed. Cir. 1995) ("The person of ordinary skill in the art is a hypothetical person who is presumed to know the relevant prior art."); Custom Accessories, Inc. v. Jeffrey-Allan Indus., Inc., 807 F.2d 955, 962 (Fed. Cir. 1986) ("The person of ordinary skill is a hypothetical person who is presumed to be aware of all the pertinent prior art.").

20. See Cybor Corp. v. FAS Techs., Inc., 138 F.3d 1448, 1480 (Fed. Cir. 1998) (en banc) (Newman, J., additional views); Electro Med. Sys., S.A. v. Cooper Life Scis., Inc., 34 F.3d 1048, 1054 (Fed. Cir. 1994) ("Claims speak to those skilled in the art."). See also 35 U.S.C. $\$ \S 103,112$ (1994).

21. Walter Benn Michaels, Against Formalism: The Autonomous Text in Legal and Literary Interpretation, 1 PoEtics TODAY 23, 27 (1979); see also Donald H. J. Hermann, Phenomenology, Structuralism, Hermeneutics, and Legal Study: Applications of Contemporary Continental Thought to Legal Phenomena, 36 U. MiAmi L. ReV. 379, 407-09 (1982); Martin F. Katz, After the Deconstruction: Law in the Age of Post-Structuralism, 24 U.W. ONTARIO L. ReV. 51, 56 (1986).

22. E. Allan Farnsworth, CONTRACts $\S 7.10$, at 512 (2d ed. 1990). 
textualist approach would consider extrinsic evidence without a threshold determination of intrinsic ambiguity. ${ }^{23}$

Any interpretive approach must take into consideration the interplay between patent law's disclosure requirements, ex post innovation practices, and technology's evolutional nature. One can argue that an interpretive theory that downplays the importance of the text or excessively relies on extrinsic context may effectively weaken the role of the patent claim as guidepost and may be detrimental to future innovation. Competitors of the patent owner may channel their inventive energies elsewhere rather than design around a patent claim having seemingly migratory borders. An aggressive search for the underlying purpose of the invention or immoderate reliance on expert testimony also raises concerns of separation of powers as they permit a judge to stray too far from the text, leading him into the Article II province of the Patent and Trademark Office ("PTO").

However, an interpretive theory, such as hypertextualism, that places too much emphasis on text is not without its problems. First, a legitimate theory of claim interpretation should embrace the technologic context and industry custom of which the claimed invention is a part. ${ }^{24}$ By characterizing claim interpretation as a question of law devoid of fact-finding and neglecting extrinsic context as an interpretive tool, the hypertextualist judge verges on abstraction and denies that language, particularly technical language, is, as Wittgenstein taught us, a "social enterprise" whose meaning is largely dependent on its context. ${ }^{25}$ Thus,

23. See infra text accompanying notes 92-98. Importantly, from the pragmatic textualist perspective, use of the artisan as an interpretive tool in patent law is quite different than the use of legislative history in the context of statutory interpretation because, unlike legislative history, the artisan is explicitly part of the patent statute see 35 U.S.C. $\S \S 103,112$ ), which, of course, was passed by both houses of Congress and presented to the President. In the context of statutory interpretation, one of the principal objections of textualists, and, I would argue, pragmatic textualists, to the use of legislative history is that the statements of committee members and individual legislators are not law. These statements do not go through the constitutionally required process of passing both houses of Congress by a majority vote and presentment to the President pursuant to Article I, § 7. See William N. Eskridge, Jr., The New Textualism, 37 UCLA L. REV. 621 (1990) (discussing objections to the use of legislative history); Frank H. Easterbrook, What Does Legislative History Tell Us?, 66 CHI.-KENT L. REV. 441 (1990).

24. Although the Federal Circuit frequently states that it interprets claims in the context of the patent, what the court actually means by "context" is the patent's intrinsic record (i.e., the claims, written description, including any drawings, and the prosecution history), not extra-textual sources. See, e.g., Pall Corp. v. Hemasure, Inc., 181 F.3d 1305, 1308 (Fed. Cir. 1999).

25. See infra note 228 . 
hypertextualism ignores the insights of contemporary legal and hermeneutic philosophy, ${ }^{26}$ and, as importantly, disregards the centrality of patent law's artisan. ${ }^{27}$ Ignoring the role of the artisan is particularly problematic given the fact that innovation in "complex technologies is the work of organizational networks" and these "[n]etworks have proven especially capable of incorporating tacit knowledge into their learning processes." ${ }^{28}$ The hypertextualist divorces himself from these ramified networks by refusing to delve into their linguistic practices. This has significant implications for ex post innovation and the adjudication of claim scope. As the hypertextualist dismisses the very tools that enable one to discern accurately not only the patentee's inventive contribution to society, but also the contribution of the patentee's competitors, the separation between industry and court widens. Although researchers will no doubt continue to pursue their agendas, the question becomes at what costs in terms of wasteful rentseeking behavior and unnecessary litigation?

Second, there are constitutional concerns with hypertextualism in that strict adherence to the patent's text ironically leads to a breakdown in separation of powers. ${ }^{29}$ The patent code explicitly empowers the PTO to examine patent applications ${ }^{30}$ and gauge patentability through the eyes of the artisan skilled in the relevant technology. ${ }^{31}$ The examiner, during the examination process, places himself in the shoes of a

26. See infra text accompanying notes 203-234.

27. Indeed, it is a basic tenet of patent law that claims are to be construed through the eyes of the artisan. See, e.g., 35 U.S.C. $\$ \S 103,112$; see also In re Cortright, 165 F.3d 1353, 1358 (Fed. Cir. 1999) ("Although the PTO must give claims their broadest reasonable interpretation, this interpretation must be consistent with the one that those skilled in the art would reach."); Multiform Desiccants, Inc. v. Medzam, Ltd., 133 F.3d 1473, 1477 (Fed. Cir. 1998) ("It is the person of ordinary skill in the field of the invention through whose eyes the claims are construed."); Hoechst Celanese Corp. v. BP Chems., Ltd., 78 F.3d 1575, 1578 (Fed. Cir. 1996) ("A technical term used in a patent document is interpreted as having the meaning that it would be given by persons experienced in the field of the invention").

28. Robert W. Rycroft \& Don E. Kash, Innovation Policy for Complex Technologies, IssUES IN SCI. \& TECH. 73, 73-74 (Fall 1999) [hereinafter Rycroft \& Kash, Innovation Policy]. Rycroft and Nash write that this tacit knowledge includes "unwritten know-how that often can be understood only with experience." Id. at 74 . See also ROBERT W. RYCROFT \& DON E. KASH, ThE Complexity Challenge: TECHNOLOGICAL INNOVAtion FOR THE $21 \mathrm{st}$ CENTURY (1999) [hereinafter RYCROFT \& KASH, THE COMPLEXITY CHALLENGE].

29. See U.S. CONST . arts. I-III.

30. See 35 U.S.C. $\$ 131$ (1994).

31. See, e.g., 35 U.S.C. $\S \S 103,112$ (1994). 
PHOSITA. $^{32}$ The patent examiner is, to a large extent, part of the technological community to which the invention, the inventor, and the inventor's competitors belong. The patentability provisions of the patent code also apply to Article III courts, including the Federal Circuit. ${ }^{33}$ By refusing to consider the artisan's perspective, the Federal Circuit assigns meaning to a claim term without employing the Congressionally mandated analytical framework set forth in Title 35. The irony is that although one would think that strict adherence to the patent's text would limit the exercise of judicial discretion, the judge, by turning a deaf ear to the skilled artisan, replaces the artisan and discerns claim meaning by examining the intrinsic record through her own eyes.

Lastly, the hypertextualists, in the name of certainty and uniformity, review claim interpretation de novo "without deference to the trial court's judgment." 34 De novo review and the concomitant diminishment of the roles of the district court and extrinsic context were a natural outgrowth of the characterization of claim interpretation as a question of law. Although certainty is a laudable goal, there is a temporal dimension to the realization of certainty. Obviously, the earlier certainty is achieved in the litigation or business-planning process the better; yet, de novo review at the Federal Circuit level leads to dilatory certainty in claim meaning. ${ }^{35}$ Furthermore, hypertextualism ignores the district court's superior institutional position with respect to extrinsic evidence. Once certainty is realized at the Federal Circuit level, that does not necessarily mean that the claim was properly interpreted. Indeed, by excluding the use of extrinsic context, the odds of reaching an incorrect interpretation are greatly enhanced. Upon a closer analysis,

32. See In re Morris, 127 F.3d 1048, 1054 (Fed. Cir. 1997) ("[T]he PTO applies to the verbiage of the proposed claims the broadest reasonable meaning of the words in their ordinary usage as they would be understood by one of ordinary skill in the art. . ."); In re Bond, 910 F.2d 831, 833 (Fed. Cir. 1990) ("It is axiomatic . . . that claim language should be read in light of the specification as it would be interpreted by one of ordinary skill in the art." (quoting In re Sneed, 710 F.2d 1544, 1548 (Fed. Cir. 1983))). See also Manual of PAtent Examining Procedure $\S 2111.01$ (7th ed. July 1998).

33. Of course, because an issued patent is presumed valid under 35 U.S.C. $\$ 282$ (1994), the Federal Circuit will focus on validity, not patentability. Nevertheless, the same code provisions applied by the PTO during prosecution of the patent are also applied by Federal Circuit in a litigation context.

34. Micro Chem., Inc. v. Great Plains Chem. Co., 194 F.3d 1250, 1257 (Fed. Cir. 1999). See also Pall Corp. v. Hemasure Inc., 181 F.3d 1305, 1308 (Fed. Cir. 1999) ("[We review construction of the claims] without deference to the rulings of the trial court.").

35. See infra text accompanying notes $149-54$. 
it is difficult to understand why, in the context of claim interpretation, de novo review is needed to promote uniformity and certainty. That is, regardless of the standard of review it employs, uniformity and certainty are achieved when the Federal Circuit exercises its exclusive appellate jurisdiction over patent issues, ${ }^{36}$ and when the district court, in appropriate circumstances, invokes the doctrine of issue preclusion. ${ }^{37}$ In the end, hypertextualism's labeling of claim interpretation as a question of law is largely artificial - a fiction that exacerbates the already difficult task of claim interpretation for the district court judge.

This article, therefore, is skeptical of hypertextualism as a theory of claim interpretation and argues that it ultimately cannot deliver on its promise of greater certainty and uniformity. As such, while both interpretive schools have as their lodestar the realization of certainty and uniformity, I argue that pragmatic textualism is the interpretive approach that can best realize these ends. ${ }^{38}$ To a large extent, Judges Rader, Newman, and Mayer are pragmatic textualists. Their opinions concerning claim interpretation demonstrate that they, "like other users of language, want to know its context, including assumptions shared by the speakers and the intended audience." ${ }^{, 39}$ Of course, the meaning that is ultimately given to the technical term must be consonant with the patent's text. This emphasis on textual internal coherence is central to pragmatic textualism, ${ }^{40}$ and the hypertextualists have correctly made this an essential part of their philosophy. However, "[t]extualism [certainly

36. See infra text accompanying notes 316-24.

37. See, e.g., TM Patents, L.P. v. Int'1 Bus. Machs., Inc., 72 F. Supp. 2d 370 (S.D.N.Y. 1999). The only situation that I can think of where de novo review is needed to promote uniformity is when issue preclusion is unavailable to the district court judge - for instance, when the patentee seeks to enforce a claim construction from a previous litigation on a defendant who was not part of that litigation. See infra text accompanying notes 310-38.

38. For an excellent discussion and analysis of the virtues of the text of a patent, particularly the claim itself, as an interpretive tool in claim interpretation, see Thomas, supra note 4.

39. Easterbrook, supra note 23, at 443.

40. As Judge Rader noted in Pitney Bowes, Inc. v. Hewlett-Packard Co., 182 F.3d 1298 (Fed. Cir. 1999), it is good counsel to "urge[] trial judges to focus on the patent document - notably the claims themselves - to ascertain the scope of patent coverage." Id. at 1314. See also Thermalloy, Inc. v. Aavid Eng'g, Inc., 121 F.3d 691, 693 (Fed. Cir. 1997) (Rader, J.) ("[T]hroughout the interpretation process, the focus remains on the meaning of claim language."); Richard A. Posner, Statutory Interpretation - in the Classroom and in the Courtroom, 50 U. CHI. L. REV. 800, 808 (1983) (asserting that in the context of statutory interpretation "words of a statute are always relevant, often decisive, and usually the most important evidence of what the statute was meant to accomplish"). 
pragmatic textualism] is not literalism, ${ }^{41}$ and, unlike hypertextualism, which cabins itself within the four corners of the patent text, the pragmatic textualist is an instrumentalist who understands that "the meaning of a word is its use in the language." ${ }^{, 42}$ As Judge Easterbrook notes, "[m]eaning comes from the ring the words would have had to a skilled user of words . . thinking about the same problem."43

In addition, the pragmatic textualists on the Federal Circuit are motivated by process considerations such as institutional competence. ${ }^{44}$ The question for them is not whether expert testimony is a question of law or fact; rather, having concluded that expert testimony (or other forms of extrinsic evidence) is useful and desirable when construing claim language, the pragmatic textualist asks: Is the trial judge or appellate judge better able to understand and incorporate expert testimony into the interpretive process? The pragmatic textualist appellate judge, well aware of his institutional limitations, opts for the former and would allow for a more deferential approach towards the district court's claim construction.

Pragmatic textualism strikes me as a judicious approach to claim interpretation. A judge who subscribes to this approach is grounded, self-aware, and empirically inclined. ${ }^{45}$ She has faith in the patent's text, but understands that the legitimacy of her faith depends upon her understanding of the technologic world around her, both in terms of

41. Manning, supra note 2, at 696. See also Bradley C. Karkkainen, "Plain Meaning": Justice Scalia's Jurisprudence of Strict Statutory Construction, 17 HARV. J.L. \& PUB. POL'Y 401, 407 (1994) (asserting that textualism embraces a "broad linguistic and cultural context"); Eileen A. Scallen, Classical Rhetoric, Practical Reasoning, and the Law of Evidence, 44 AM. U. L. REV. 1717, 1751 (1995) ("Text comes first, not because it 'speaks for itself,' but because it is the touchstone.")

42. Ludwig Wittgenstein, Philosophical Investigations $\S 43$ (G.E.M. Anscombe trans., 2d ed. 1958). See also Eastman Kodak Co. v. Goodyear Tire \& Rubber Co., 114 F.3d 1547, 1555 (Fed. Cir. 1997) (Rader, J.) (“As a general rule, the construing court interprets words in a claim as one of skill in the art at the time of invention would understand them. "); Pall Corp. v. Micron Separations, Inc., 66 F.3d 1211, 1224 (Fed. Cir. 1995) (Mayer, J., concurring) ("Claim interpretation demands an objective inquiry into how one of ordinary skill in the relevant art at the time of the invention would comprehend the disputed word or phrase in view of the patent claims, specification, and prosecution history.").

43. Frank H. Easterbrook, The Role of Original Intent in Statutory Construction, 11 HaRv. J.L. \& PUb. Pol'y 59, 61 (1988). See also Green v. Bock Laundry Mach. Co., 490 U.S. 504, 528 (1989) (Scalia, J., concurring in the judgment) (asserting that the meaning of terms in statutes should be determined by the meaning that is "most in accord with context and ordinary usage.").

44. See infra text accompanying notes 280-86.

45. See POSNER, supra note 1, at 4-21 (discussing what a pragmatist values). 
discerning claim meaning and, once discerned, the effect the meaning will have on the technological community to which the invention belongs. ${ }^{46}$

Part II of this article focuses on the origins of hypertextualism, its culmination in the Federal Circuit, and the events that gave rise to the current ideological struggle between the hypertextualists and the pragmatic textualists. It also discusses the potential adverse effect of hypertextualism on patent law's expost incentives, namely improvement theory and design-around theory. Part III explores the importance of extrinsic context and underlying assumptions to a claim interpretation analysis. I also discuss the centrality of the hypothetical artisan to the patent system, as well as the artisan's role as representative of industry custom and culture. Part III also explores the relevance to claim interpretation of process and functional considerations such as institutional competence, early certainty, and issue preclusion. Lastly, I address how a judge should confront persistent ambiguity by exploring the application of canons of claim interpretation as default rules.

\section{The Federal Circuit's HyperteXtualism}

\section{A. The Markman Revolution and the Beginning of Hypertextualism}

\section{Markman I: PHOSITA Blinded}

Many Federal Circuit judges in recent years have understandably expressed their frustration with inept or purposively vague claim drafting, ${ }^{47}$ the uncertainties that accompany the equitable doctrine of

46. See Thomas C. Grey, What Good Is Legal Pragmatism?, in Pragmatism IN LAW AND SOCIETY 9, 15 (Michael Brint \& William Weaver eds., 1991) ("We pragmatists keep in the back of our minds the reminder that we are thinking to some end - thinking instrumentally. We also keep there a reminder that we are thinking against a background of tacit presupposition of which we can never be fully aware thinking contextually.") (emphasis in original). Although the emphasis on instrumentalism is consistent with the traditional utilitarian justification of the American intellectual property regime, it would be incorrect to equate pragmatism with the ulitilitarianism of Bentham. As Thomas Cotter notes, "A pragmatist may be interested not only in the substantive consequences of a given rule, but also in its systematic and expressive consequences." Thomas F. Cotter, Pragmatism, Economics, and the Droit Moral, 76 N.C. L. Rev. 1, 29 n.153 (1997); see also Thomas F. Cotter, Legal Pragmatism and the Law and Economics Movement, 84 GEO. L.J. 2071, 2085, nn.55-56, 2091-95 \& 2135 (1996).

47. See, e.g., ZMI Corp. v. Cardiac Resuscitator Corp., 844 F.2d 1576, 1583 (Fed. 
equivalents, ${ }^{48}$ and the vicissitudes of the jury in patent cases. ${ }^{49}$ Similar to the atmosphere in the late nineteenth century, ${ }^{50}$ this frustration

Cir. 1988) (Nichols, J., dissenting) (stating that with reference to claim drafting, "[w]e are up against what we must realistically consider a growing inability of speakers and writers, lawyers, technicians, and laymen, to say what they intend to say with accuracy and clarity.").

48. See, e.g., London v. Carson Pirie Scott \& Co., 946 F.2d 1534, 1538 (Fed. Cir. 1991) (Lourie, J.) ("Application of the doctrine of equivalents is the exception, however, not the rule, for if the public comes to believe (or fear) that the language of patent claims can never be relied on, and that the doctrine of equivalents is simply the second prong of every infringement charge, regularly available to extend protection beyond the scope of the claims, then claims will cease to serve their intended purpose. Competitors will never know whether their actions infringe a granted patent.").

49. See, e.g., Judge Paul R. Michel, Improving Patent Jury Trials, 532 PLI/Pat 77, 81 (1998) ("The very unpredictability of jury verdicts not only undermines opinion letters, but discourages license agreements and design-arounds, and multiplies litigation — with attendant costs in money, disruption and delay.").

50. In the early nineteenth century, there was no statutory requirement to claim an invention. The Patent Act of 1793 simply required the applicant to "distinguish [his invention] from all other things before known." Patent Act of 1793, § 3, 1 Stat. 318, 321 (repealed 1836). Despite the lack of a statutory claim requirement, applicants began to include claim-type language in their patents. These inchoate claims were eventually used with greater frequency. Applicants would engage in what was known as central claim drafting, whereby an applicant would describe his invention in a claim and thereafter include the phrase "as substantially as described herein" or some variation thereof. During litigation, the court would peruse the written description and the drawings to determine the "principle that formed the inventive idea or solution underlying the claim language." Toshiko Takenaka, Doctrine of Equivalents After Hitlon-Davis: A Comparative Law Analysis, 22 Rutgers Computer \& TeCh. L.J. 479, 502 (1996). This practice was so common that when the Patent Act of 1836 was passed, it was "understood as merely codifying the existing law which had been developed by the courts." Karl B. Lutz, Evolution of the Claims of U.S. Patents, 20 J. Pat. \& TRADEMARK OfF. SOC'Y 134, 143 (1938). The word "claim" found its way into the 1836 Patent Act, and as a result, assumed greater importance. Nevertheless, the claim was still not regarded as the central feature of the patent document even though applicants began to draft claims more specifically by expending a "great deal of effort . . . in formulating claims, and the practice grew of presenting a profusion of claims of varying form and scope." William Redin Woodward, Definiteness and Particularity in Patent Claims, 46 Mich. L. Rev. 755, 764 (1948). As the emphasis on claims grew, however, so did the ease with which a competitor could circumvent claims by making minor modifications to his product, thus avoiding literal infringement. The Supreme Court responded to this practice in Winans v. Denmead, 56 U.S. 330 (1 How. 1853), wherein the Court held that a device may infringe a patent claim despite the fact that the claim did not literally read on the device. Thus, the Court looked beyond the four corners of the patent claim and established what became known as the doctrine of equivalents. Many viewed Winans and its progeny as a threat to the notice function of the patent claim, and in 1870 Congress, for the first time, specifically required the patent applicant to claim his invention distinctly and with particularity. This new 
prompted some judges to reemphasize the importance of certainty, uniformity, and predictability in patent law; one way to establish this virtuous triumvirate is to champion, as the hypertextualists have done, the notice function of the patent claim. ${ }^{51}$ Given that 35 U.S.C. $\S 112$ requires the patentee to "particularly" point out and "distinctly" claim what he "regards as his invention," competitors of the patentee should be able to discern the boundaries of the patentee's proprietary interest without lifting their eyes from the patent's text. ${ }^{52}$

As we will see, the hypertextualist "movement" ineluctably led to the elimination of the jury from the issue of claim interpretation, a development generally regarded as positive by the patent bar. ${ }^{53}$

requirement, which came to be known as peripheral claiming, was designed to "accommodate the notice function of claims." Joseph S. Cianfrani, An Economic Analysis of the Doctrine of Equivalents, 1 VA. J.L. \& TECH. 1, 13 (1997). It accomplished this by increasing the reliability "on claims by the public by limiting the bounds of the patent to that covered by the claims and a narrow range of equivalents." Id. at 14. Central claiming was officially dead, and much like the hypertextualist's atmosphere today, the patent claim in 1870 held center stage. See, e.g., Merrill v Yeomans, 94 U.S. 568, 570 (1876) (asserting that the claim is of "primary importance" in ascertaining exactly what is patented).

51. See, e.g., Pitney Bowes, 182 F.3d at 1311 (Michel, J.) (referring to notice function of claims); Sextant Avionique, S.A. v. Analog Devices, Inc., 172 F.3d 817, 830 (Fed. Cir. 1999) (Lourie, J.) (referring to notice function of claims).

52. See, e.g., Litton Systems, Inc. v. Honeywell, Inc., 145 F.3d 1472, 1474 (Fed. Cir. 1998) (Gajarsa, J., dissenting from the Order declining the suggestion for rehearing in banc) ("Public notice of the scope of the right to exclude, as provided by the patent claims, specification and prosecution history, is a critical function of the entire scheme of patent law. The notice function is critical because it provides competitors with the necessary information upon which they can rely to shape their behavior in the marketplace.”); Hoganas AB v. Dresser Indus., 9 F.3d 948, 951, (Fed. Cir.1993) (stating function of claims is "putting competitors on notice of the scope of the claimed invention"); Merrill, 94 U.S. at 573-74 (1876) ("It seems to us that nothing can be more just and fair, both to the patentee and to the public, than that the former should understand, and correctly describe, just what he has invented, and for what he claims a patent.").

53. See ABA Section of Intellectual Property Law, Resolutions Acted Upon by Council: August 1995-1996, 1996 ABA SEC. INTEllectuAl Property LAW ReP. 19 (containing text of Resolution 605-1, which the Council approved in October of 1995):

RESOLVED, that the Section of Intellectual Property Law reaffirms in principle that construing patent claims to define the scope of the patent right is a question of law that is treated, by both the trial and appellate courts, identical to statutory construction, and specifically, the Section recommends that the ABA file an amicus brief on the merits in the United States Supreme Court in support of the Respondent in Markman $v$. Westview Instruments, Inc. 
However, reducing the jury's role in patent litigation was only the first step. In what ultimately justifies the label "hypertextualism," the court characterized claim interpretation as a question of law subject to de novo review, thus rendering the patent's text the principal, and for all practical purposes, the sole interpretive tool - a tool that, according to the hypertextualists, is rarely ambiguous. As such, in the name of certainty, uniformity, and predictability, the respective roles of the trial judge and the expert witness have been greatly marginalized, while the influence of the Federal Circuit, in turn, has been significantly augmented.

The importance of the notice function of the patent claim has always been appreciated, or at least understood by judges on the Federal Circuit and its predecessor, the Court of Customs and Patent Appeals. However, it was not until the 1995 en banc Federal Circuit decision in

See also ABA Section of Intellectual Property Law, 1996 Fall Council Meeting, 1996 ABA Sec. Intellectual Property LAW Rep. 19 ("[T] Briefs Committee] was 19-3 to support the Respondent over the Petitioner."); Joseph R. Re, Understanding Both Markman Decisions, 456 PLI/PAT 77, 92 (1996) ("The patent bar apprehensively read the [Supreme Court's Markman] decision and breathed a sigh of relief."); Arthur Wineburg, What Hath Markman Wrought?, IP WORLDWIDE, Sept. / Oct. 1996, at 1, 4 ("This decision will greatly increase the predictability and uniformity of interpretations of patent claims."); Richard A. Machonkin, Note: Markman v. Westview Instruments, Inc. and Hilton Davis Chemical Co. v. WarnerJenkinson Co.: The Federal Circuit Gets Its Laws and Its Facts Straight, 9 HARV. J.L. \& TECH. 181, 203 (1996) ("Both Markman and Hilton Davis properly allocate the burdens of adjudication between judge and jury."); William R. Zimmerman, Note: Unifying Markman and Warner-Jenkinson: A Revised Approach to the Doctrine of Equivalents, 11 HARV. J.L. \& TECH. 185, 267 (“Markman . . . developed a uniform and consistent inquiry for assessing literal infringement."); Federal Circuit Holds Fourteenth Annual Judicial Conference, BNA PAT., Trademark \& COPYRIGHT L. DAILY, July 5, 1996, at D3 ("[Practitioner Lawrence] Pretty speculated that [Markman] will result in more predictability where claim construction is involved[,] . . . spur early motions for summary judgment and . . more settlements in patent cases[, and] . . . a swinging of the pendulum back to more court trials and away from jury trials."); Holmes J. Hawkins III, Claim Interpretation in a Post-Markman Environment, 572 PLI/PAT 681, 709 (1999) ("One of the most important legacies of the Markman decision is that parties now have the ability to identify and resolve claim interpretation issues at a much earlier stage than before.”). But see Donald R. Dunner \& Howard A. Kwon, Cybor Corp v. FAS Technologies: The Final Say on Appellate Review of Claim Construction?, 80 J. PAt. \& Trademark OfF. SoC'y 481, 497 (1998) ("The Federal Circuit's plenary authority over the claim construction process may have harsh results in practice and may undermine the juridical role of the district courts in patent litigation.”); William F. Lee, The Ever Confounding Question of Claim Construction: Markman and Its Progeny, 531 PLI/PAT 151, 153 (1998) ("[The] impact [of Markman], unfortunately, has not necessarily been that desired or expected.”). 
Markman v. Westview Instruments, Inc. ${ }^{54}$ (Markman I) that it reached the forefront of patent law jurisprudence. Prior to Markman I's arrival at the doors of the Federal Circuit, the court was well aware of the concerns of the patent bar regarding the susceptibility and credulity of juries in patent cases, particularly with respect to the issue of claim interpretation. ${ }^{55}$ Markman I provided the court with an opportunity to address these concerns.

The principal issue in Markman I seemingly boiled down to one of institutional competence: who is better able to interpret patent claims judge or jury? ${ }^{56}$ In finding that the judge was best suited to interpret patent claims, the Federal Circuit provided several functional reasons. For instance, the court focused on tradition, ${ }^{57}$ gravity of the decision, ${ }^{58}$ predictability, ${ }^{59}$ and uniformity. ${ }^{60}$ This part of the court's analysis was

54. 52 F.3d 967 (Fed. Cir. 1995) (en banc).

55. See, e.g., Michael A. Sartori, An Economic Incentives Analysis of the Jury's Role in Patent Litigation, 79 J. PAT. \& TRADEMARK OFF. SOC'Y, 331, 333 (1997) ("[I]n time with the questioning by the patent legal community, the Court of Appeals for the Federal Circuit entered the foray and questioned the jury's role in three areas of patent litigation," including claim interpretation.).

56. There were also constitutional issues pertaining to the Seventh Amendment right to a jury that are beyond the scope of this article and not particularly germane to my thesis.

57. See Markman, 52 F.3d at 978 (asserting that a patent is a written instrument and "[i]t has long been and continues to be a fundamental principle of American [patent] law that 'the construction of a written evidence is exclusively with the court."').

58. See id. ("When a court construes the claims of the patent, it is as if the construction fixed by the court had been incorporated in the specification,' and in this way the court is defining the federal legal rights created by the patent document.") (quoting George T. CURTIS, A TREATISE ON THE LAW OF PATENTS FOR Useful INVENTIONS $\$ 452$, at 609 (4th ed. 1873)).

59. See id. at 978-79 ("[I]t is only fair (and statutorily required) that competitors be able to ascertain to a reasonable degree the scope of the patentee's right to exclude ... They may understand what is the scope of the patent owner's rights by obtaining the patent and prosecution history - 'the undisputed public record' — and applying established rules of construction to the language of the patent claim in the context of the patent. Moreover, competitors should be able to rest assured, if infringement litigation occurs, that a judge, trained in the law, will similarly analyze the text of the patent and its associated public record and apply the established rules of construction, and in that way arrive at the true and consistent scope of the patent owner's rights to be given legal effect.") (quoting Senmed, Inc. v. Richard Allan Med. Indus., 888 F.2d 815, 819 n.8 (Fed. Cir. 1989)).

60. See id. at 979 ("To treat the nature of the patented invention as a matter of fact, to be inquired of and determined by a jury, would at once deprive the inventor of the opportunity to obtain a permanent and universal definition of his rights under the patent.") (quoting William C. ROBInson, ThE LAW OF PATENTS FOR Useful 
well-reasoned, and the opinion should have ended there. However, perhaps inclined to establish itself as the arbiter of claim meaning and to enhance its power to oversee patent infringement disputes, the court went on to find that claim interpretation is a question of law subject to de novo review:. ${ }^{61}$

We . . . hold that in a case tried to a jury, the court has the power and obligation to construe as a matter of law the meaning of language used in the patent claim .... Because claim construction is a matter of law, the construction given the claims is reviewed de novo on appeal. ${ }^{62}$

It is important to point out that the court did not have to reach (or create) the law/fact issue to find that a judge is better able than a jury to interpret claims. ${ }^{63}$ It could very easily have justified its decision on the functional or institutional considerations that it articulated.

Moreover, by addressing the law/fact issue, the court painted itself into a corner with respect to the issue of extrinsic evidence because it was now faced with the prospect of reconciling the use of factually intensive expert testimony by district court judges with its holding that claim interpretation is a question of law subject to de novo review. The court finessed this issue by focusing on the informational aspects of expert testimony. According to the court, because a district court judge may not be technologically savvy, "[e]xtrinsic evidence . . . may be necessary to inform the court about the language in which the patent is

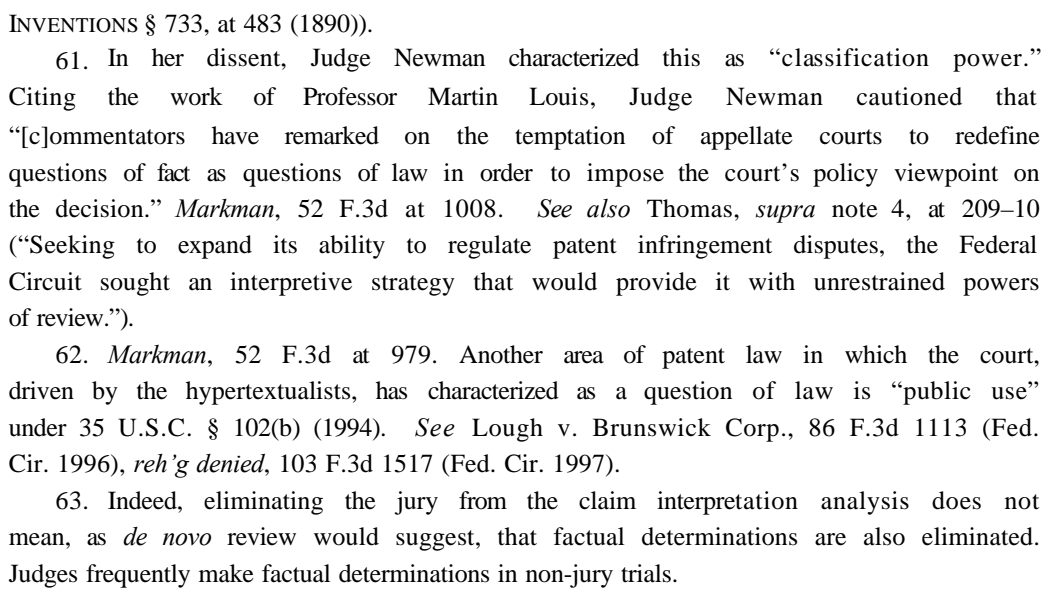

62. Markman, 52 F.3d at 979. Another area of patent law in which the court, driven by the hypertextualists, has characterized as a question of law is "public use" under 35 U.S.C. § 102(b) (1994). See Lough v. Brunswick Corp., 86 F.3d 1113 (Fed. Cir. 1996), reh'g denied, 103 F.3d 1517 (Fed. Cir. 1997).

63. Indeed, eliminating the jury from the claim interpretation analysis does not mean, as de novo review would suggest, that factual determinations are also eliminated. Judges frequently make factual determinations in non-jury trials. 
written." ${ }^{64}$ Of note, the court went on to admonish that "this evidence is not for the purpose of clarifying ambiguity in claim terminology." ${ }^{95}$ As the court explained, "It is not ambiguity in the document that creates the need for extrinsic evidence but rather unfamiliarity of the court with the terminology of the art to which the patent is addressed." expert testimony is merely to be used as an educational tool, "the court is not crediting certain evidence over other evidence or making factual evidentiary findings. ${ }^{\circ 7}$ However, in a seemingly contradictory assertion, the majority also noted that "the focus" of a claim interpretation analysis "is on the objective test of what one of ordinary skill in the art at the time of the invention would have understood the term to mean." ${ }^{\circ}$ Thus, on the one hand, the artisan can be used only as an "educational tool"; yet, on the other hand, the court is to discern what the artisan "would have understood" the claim language to mean.

The majority's conflicting language was highlighted by Judge Newman in a lengthy dissent in which she characterized the litigation system created by the majority opinion as "unworkable, and ultimately unjust." ${ }^{\circ 9}$ For Judge Newman, the role of the expert is indispensable in interpreting claims because "[p]atents are technologic disclosures, written by and for the technologically experienced: those 'of skill in the art." "'70 In adopting a de novo standard, the majority is denying that the meaning and scope of disputed technical terms are classical questions of fact that are most efficiently and effectively discovered at the trial level. ${ }^{71}$

The ideological lines were drawn in Markman I, and subsequent cases provided the pragmatic textualists with an opportunity to

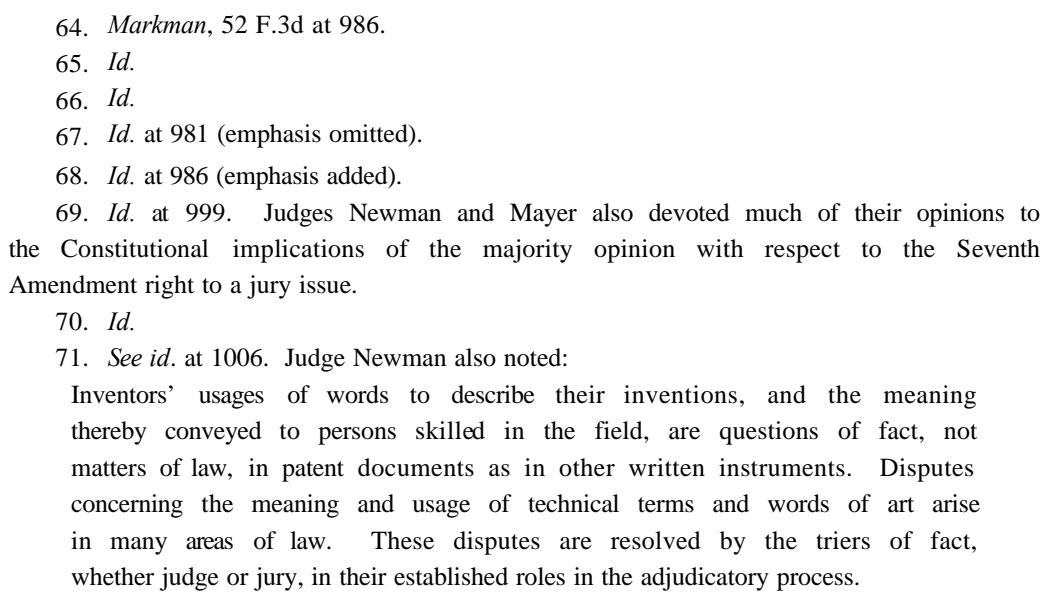


elaborate upon their position. ${ }^{72}$ During the ensuing intra-circuit split, the Supreme Court reviewed Markman I.

\section{Markman II and the Origins of the Pragmatic Textualist Upheaval}

The Supreme Court, in an opinion written by Justice Souter, unanimously affirmed the Federal Circuit's holding that claim interpretation is solely for the judge. ${ }^{73}$ The Court, like the Federal Circuit, based its decision on "functional considerations" such as uniformity and the judge's "training in exegesis." 74 However, two additional points need to be made about the Supreme Court's Markman opinion, the first concerning the relationship between expert testimony and claim interpretation, and the second involving the proper standard of review. The Supreme Court's treatment, or lack thereof, of these two issues provided both an affirmation of the hypertextualist's position and an impetus for a pragmatic textualist upheaval.

72. For example, in Hoechst Celanese Corp. v. BP Chemicals, Ltd., 78 F.3d 1575 (Fed. Cir. 1996), Judge Newman again expressed her displeasure with Markman I. In Hoechst, the claimed invention related to a method for reducing iodide contamination in an organic medium by the addition of a macroreticulated silver-charged cation exchange resin. The claim stated that the resin must be "stable in the organic medium." Id. at 1578. In the written description, "stable" was defined as that which would not break down or "change more than about 50 percent of its dry physical dimension . . ." Id. at 1578-79 (emphasis added). The parties could not agree on the meaning of the word "dimension." Although the court ultimately relied on the written description to resolve the dispute, Judge Newman was clearly receptive to extrinsic evidence introduced during the trial:

\footnotetext{
The parties have provided us with photographs and experimental data, the testimony of the scientists who produced the data and interpreted it, and the testimony of experts in the field. Markman [I] limits appellate reliance on extrinsic evidence to evidence in explanation of the technology and technical terms . . . . However, we have found it necessary to rely on the evidence presented at the trial and credit certain evidence over other evidence, for we are not personally qualified to know the scientific meanings of "stable" and "dimension" as applied to macroreticulated cation-exchange resins in organic medium.
}

Id. at 1579. Judge Mayer has also expressed his discontent with Markman I. See, e.g., Pall Corp. v. Micron Separations, Inc., 66 F.3d 1211, 1224 (Fed. Cir. 1995) (Mayer, J., concurring) ("I continue to believe that Markman was wrongly decided.").

73. See Markman v. Westview Instruments, Inc., 517 U.S. 370 (1996).

74. Id. at 388 . 
a. "Internal Coherence" and the Role of Extrinsic Evidence

In holding that claim interpretation was solely an issue for the judge, the Supreme Court addressed the jury's role in making credibility determinations. ${ }^{75}$ The Court stated that "any credibility determinations will be subsumed within the necessarily sophisticated analysis of the whole document." 76 Thus, while recognizing the value of expert testimony, the Court emphasized the primacy of the patent's text as an interpretive tool. According to the Court, " $[\mathrm{t}] \mathrm{he}$ decisionmaker vested with the task of construing the patent is in the better position to ascertain whether an expert's proposed definition fully comports with the specification and claims and so will preserve the patent's internal coherence." "77 Juries typically make credibility determinations that "are much less significant than a trained ability to evaluate the testimony in relation to the overall structure of the patent." ${ }^{\prime 78}$ The hypertextualists have understood the Court's subsumption of credibility determinations "within the whole document" and emphasis on the preservation of the "patent's internal coherence" to mean that the intrinsic record enjoys a certain interpretive primacy. While expert testimony may be helpful from an "educational" standpoint, it cannot contradict the unambiguous text of the patent.

Consider the Federal Circuit's opinion in Vitronics Corp. v. Conceptronic, Inc. ${ }^{79}$ the first significant claim interpretation case after Markman II. The court in Vitronics provided district court judges and the patent bar with an interpretive, if not mechanical, road map that, when read properly, would rarely lead to the use of expert testimony. The court stated that "where the public record [i.e., claims, written description, and prosecution history] unambiguously describes the scope of the patented invention, reliance on any extrinsic evidence is improper." ${ }^{10}$ The rationale is that "competitors are entitled to review the public record, apply the established rules of claim construction,

\footnotetext{
75. See id. at $388-90$.

76. Id. at 389 .

77. Id. at 390 (emphasis added).

78. Id.

79. 90 F.3d 1576 (Fed. Cir. 1996).

80. Id. at 1583. See also Georgia-Pacific Corp. v. United States Gypsum Co., 195 F.3d 1322, 1332 (Fed. Cir. 1999) ("[W]hen intrinsic evidence is unambiguous, it is improper for the court to rely on extrinsic evidence to contradict the meaning of the claims.”); Robotic Vision Sys., Inc. v. View Eng'g, Inc., 189 F.3d 1370, 1375 (Fed. Cir. 1999) ("Often, the intrinsic evidence alone will resolve any ambiguity in a disputed claim term, and in such instances, reliance on extrinsic evidence is improper.").
} 
ascertain the scope of the patentee's claimed invention and, thus, design around the claimed invention." ${ }^{81}$ Vitronics clearly is a hypertextualist case, but an interesting question arises from the court's opinion: If it is improper to consider extrinsic evidence when the intrinsic evidence is unambiguous, then is it proper to consider extrinsic evidence when the intrinsic evidence is ambiguous? This inference is seemingly contrary to Markman I's admonishment that "[i]t is not ambiguity in the document that creates the need for extrinsic evidence." 82 But the Federal Circuit, redolent of the parol evidence rule, has stated in a postVitronics opinion that "reliance on extrinsic evidence to interpret claims is proper only when the claim language remains genuinely ambiguous after consideration of the intrinsic evidence." ${ }^{83}$ This statement, while made in the context of criticizing the district court for improperly considering expert testimony, seemed to open the door for the use of expert testimony as an interpretive tool, in addition to its use as an informational tool.

However, this ambiguity requirement has problems that lie at the heart of a hypertextualist approach to claim interpretation. First, the phrase "genuinely ambiguous" is itself ambiguous. Second, by requiring a finding of ambiguity before permitting the use of expert testimony as an interpretive aid, the hypertextualists, ironically, have provided a perverse incentive for civil litigants to introduce evidence tending to show ambiguity, further complicating the situation for the district court judge. ${ }^{84}$ Lastly, as claims are written by and for skilled artisans, ${ }^{85}$ how is ambiguity discerned without considering extrinsic

81. Vitronics, 90 F.3d at 1583.

82. Markman, 52 F.3d at 987.

83. Bell \& Howell Document Mgmt. Prods. Co. v. Altek Sys., 132 F.3d 701, 706 (Fed. Cir. 1997).

84. See, e.g., Sextant Avionique, S.A. v. Analog Devices, Inc., 172 F.3d 817, 825 (Fed. Cir. 1999) ("Sextant's claim construction arguments hinge on an ironic contention: that the evidence intrinsic to its own patent is ambiguous and insufficient to construe the claims, thus requiring resort to extrinsic evidence such as expert testimony."); David J. Brezner, Presenting the Witnesses Special to a Patent Trial, in PAtent Litigation 1998, at 61, 75-76, (PLI Pats., Copyrights, Trademarks, and Literary Prop. Course, Handbook Series No. G0-002O, 1998) (“[I]n order to set a foundation for use of technical expert testimony on the meaning of specific claim limitations, it is imperative for the party to establish an ambiguity in each of the limitations for which such testimony is offered.").

85. See Pall Corp. v. Micron Separations, Inc., 66 F.3d 1211, 1224 (Fed. Cir. 1995) (Mayer, J., concurring) ("A patent . . . is written for a person of ordinary skill in an art; it is not written for a court."); James B. Altman et al., The Law of Patent Claim Interpretation: The Revolution Isn't Finished, 8 FED. CIR. B.J. 93, 102-03 (1998) ("Vitronics — at least as a number of courts appear to have applied it - is inconsistent 
context? ${ }^{86}$ Indeed, "the decision that a text is ambiguous cannot be made prior to the introduction of extrinsic evidence." ${ }^{87}$ Meaning is not "in the word" "88; rather, it is in the technological social practice or custom, and "usages and customs are a part of those circumstances by which the meaning of words is to be judged." ${ }^{\circ 9}$

Although there has arguably been a modest retreat from Vitronics, ${ }^{90}$ the open door for the use of expert testimony as an interpretative tool has proved to be illusory. Wedded solely to notions of "internal coherence" and the notice function of the patent claim, the hypertextualist majority has remained steadfast in their skepticism of expert testimony. ${ }^{91}$ A particularly troubling trend is that in those rare

with the established standard for construing patent claims. The courts traditionally have attempted to interpret them consistently with the understanding of persons skilled in the relevant field of technology. Yet Vitronics has been read to encourage judges to ignore that understanding so long as the court thinks that the patent documents are clear.").

86. As stated by Arthur Corbin, well known for his narrow approach to the application of the parol evidence rule, "[s]eldom should the court hold that the written words exclude evidence of the custom, since even what are often called 'plain' meanings are shown to be incorrect when all the circumstances of the transaction are known. . ." Arthur L. Corbin, Corbin on Contracts $\S 555$ at 239 (1960). With respect to contract construction, Professor Farnsworth has noted that "the trend has favored Corbin's view." 2 E. Allan FARnsworth, FARnsworth ON CONTRACTS $\S 7.3$, at 216 (2d ed. 1998); see also Stephen F. Ross \& Daniel Tranen, The Modern Parol Evidence Rule and Its Implications for New Textualist Statutory Interpretation, 87 GEO. L.J. 195, 205 (1998) ("The Restatement (Second) of Contracts radically departed from its predecessor's approach to plain meaning of contract text and to the admissibility of parol evidence, largely due to Corbin's influence."); Metric Constructors, Inc. v. Nat'l Aeronautics \& Space Admin., 169 F.3d 747, 753 (Fed. Cir. 1999) ("The [legal] commentaries agree that courts should use evidence of trade practice and custom not only to determine the meaning of an ambiguous provision, but to determine whether a contract provision is ambiguous in the first instance.").

87. Michaels, supra note 21 , at 30.

88. Id.

89. CORBIN, supra note $86, \S 555$, at 239 . In the context of contract interpretation, Professor Farnsworth notes that the Supreme Court of Alaska has abandoned the rule "that resort to extrinsic evidence can take place only after a preliminary finding of ambiguity" on the ground that it is "artificial and unduly cumbersome." FARNSWORTH, supra note 86, § 7.12, at 294 (quoting Alyeska Pipeline Serv. Co. v. O’Kelley, 645 P.2d 767, 771 n.1 (Alaska 1982).

90. See, e.g., Pitney Bowes, Inc. v. Hewlett-Packard Co., 182 F.3d 1298, 1308-09 (Fed. Cir. 1999); Key Pharms. v. Hercon Labs. Corp., 161 F.3d 709, 716 (Fed. Cir. 1998). I should note that I am talking about a district court's reliance on extrinsic evidence, not admissibility.

91. In many ways, the hypertextualist approach to claim interpretation is analogous to a hypertextualist application of the Chevron doctrine. See Pierce, supra note 12. The Chevron doctrine requires an appellate court reviewing an agency's interpretation 
instances where intrinsic ambiguity is found, the hypertextualists, without considering extrinsic evidence, have applied default rules or canons of claim construction..$^{92}$ Default rules are essential to claim construction, ${ }^{93}$ but the application of a default rule should come after extrinsic evidence is heard. Prior to introduction of extrinsic evidence the existence vel non of ambiguity and the type of ambiguity are uncertain. ${ }^{94}$ Does "ambiguity" signify that the claim language is unintelligible or, in patent parlance, indefinite? Or, does it denote that the claim language can mean either A or B $?^{95}$ Consideration of extrinsic evidence ex ante is important in answering these questions. Assuming the claim is ultimately found ambiguous, extrinsic evidence will most likely determine the nature of the "ambiguity," which will have a direct impact on the claim's validity under 35 U.S.C. $§ 112$, If $2 .{ }^{96}$ If

of a statute initially to ask if Congress spoke to the issue at hand (i.e., is the statute ambiguous). See Chevron U.S.A., Inc. v. Natural Res. Defense Council, Inc., 467 U.S. 837,842 (1984). If the court finds that the statute is unambiguous, "that is the end of the matter; for the court, as well as the agency, must give effect to the unambiguously expressed intent of Congress." Id. at 842-43. On the other hand, if ambiguity exists, the court must review the agency's interpretation of the statute to determine whether it is "based on a permissible construction of the statute." $I d$. at 843 . Just as hypertextualism on the Federal Circuit will rarely lead to a finding of claim ambiguity, some commentators have asserted that "hypertextualism" on the Supreme Court has seldom led to a finding of statutory ambiguity, thereby eviscerating the Chevron doctrine. See Pierce, supra note 12; see also Thomas W. Merrill, Textualism and the Future of the Chevron Doctrine, 72 WASH. U. L.Q. 351 (1994).

92. See, e.g., Athletic Alternatives, Inc. v. Prince Mfg., Inc., 73 F.3d 1573 (Fed. Cir. 1996); Ethicon Endo-Surgery, Inc. v. United States Surgical Corp., 93 F.3d 1572 (Fed. Cir. 1996).

93. See infra text accompanying notes 335-44 for a discussion of canons of claim construction as default rules.

94. Judge Posner has written in the context of contract interpretation: A completely intractable issue of contract interpretation can be resolved only by the application of some default rule... . But the time to throw up one's hands and apply such a rule is after extrinsic evidence has been considered. For until then, we do not know whether we have an intractable interpretive issue or merely an issue that cannot be resolved without testimony or other evidence besides the language and logic . . . of the contract.

Bidlack v. Wheelabrator Corp., 993 F.2d 603, 609 (7th Cir. 1993) (en banc).

95. See, e.g., A.B. Dick Co. v. Burroughs Corp., 713 F.2d 700, 703 (Fed. Cir. 1983) (noting that the district court decided that the limitation that the droplets are "deflected laterally" was ambiguous, for it could mean deflection "lateral" of the undisturbed stream of droplets from the nozzle or the deflection "lateral" of the movement between nozzle and paper).

96. 35 U.S.C. $\S 112$ requires the patent applicant to "particularly point[] out and distinctly claim[] the subject matter which the applicant regards as his invention." See 
ambiguity means that the claim language can mean either A or B, then the validity of that claim is likely to be upheld. ${ }^{97}$ However, if the claim language is indefinite (i.e., there are no competing constructions), the claim will probably be invalidated. ${ }^{98}$

\section{b. Claim Interpretation as a "Mongrel Practice"}

The second point relating to the Supreme Court's Markman decision concerns the proper standard of review for claim interpretation. Although not directly addressing this issue, the Court, in what proved to be controversial dicta, stated that the issue of claim interpretation is a "mongrel practice" a pristine legal standard and a simple historical fact." 100 This language breathed new life into the pragmatic textualists, who, sensing an opening, conflated the issues of expert testimony and standard of review. These judges, using hypertextualism's own terms, eagerly seized upon Justice Souter's law/fact language to assert that claim interpretation involved significant factual determinations centering around the use of expert testimony. ${ }^{101}$ Because claim interpretation was

Personalized Media Communications, L.L.C. v. Int'1 Trade Comm'n, 161 F.3d 696, 705 (Fed. Cir. 1998) (stating "whether a claim is definite requires an analysis of "whether one skilled in the art would understand the bounds of the claim when read in light of the specification . . . . If the claims read in light of the specification reasonably apprise those skilled in the art of the scope of the invention, § 112 demands no more."'); N. Am. Vaccine, Inc. v. Am. Cyanamid Co., 7 F.3d 1571, 1579 (Fed. Cir. 1993) ("Whether a claim is invalid for indefiniteness depends on whether those skilled in the art would understand the scope of the claim when the claim is read in light of the specification.").

97. See, e.g., Athletic Alternatives, 73 F.3d at 1581 ("Where there is an equal choice between a broader and a narrower meaning of a claim, and there is an enabling disclosure that indicates that the applicant is at least entitled to a claim having the narrower meaning, [the] notice function of the claim [is] best served by adopting the narrower meaning."); Ethicon Endo-Surgery, 93 F.3d at 1581-82 (applying Athletic Alternatives default rule). Of course, as Judge Nies advocated in Athletic Alternatives, the claim may alternatively be invalidated under this scenario. See Athletic Alternatives, 73 F.3d at 1583 (Nies, J., concurring in result). See infra text accompanying notes 335-44.

98. See, e.g., Morton Int'l, Inc. v. Cardinal Chem. Co., 5 F.3d 1464, 1470 (Fed. Cir. 1993) (holding patent claims invalid for indefiniteness); Amgen, Inc. v. Chugai Pharm. Co., 927 F.2d 1200, 1217-18 (Fed. Cir. 1991) (holding patent claims invalid for indefiniteness).

99. Markman v. Westview Instruments, Inc., 517 U.S. 370, 378 (1996).

100. Id. at 388 .

101. Ideally, for the pragmatic textualists, the law/fact distinction should be avoided. However, given this opening in Markman II and the constraints of Federal Circuit precedent, the pragmatic textualists perhaps felt that change could best be realized by 
not a pure question of law, the pragmatic textualists argued that de novo review, while acceptable for the ultimate legal conclusion on claim scope, was not the sole standard of review. Rather, the court should review the factual findings more deferentially. This argument allowed the pragmatic textualists to advance what they considered to be a central precept of claim interpretation: extrinsic evidence plays a fundamental role in claim construction.

\section{B. An Ideological Badinage in the Wake of Markman II}

In the wake of Markman II, the hypertextualists continued to emphasize the primacy of the intrinsic record and the de novo standard of review. ${ }^{102}$ Although they opined that extrinsic evidence may be used as an interpretive tool in the face of ambiguity, the hypertextualists, as mentioned above, nearly always found that the intrinsic record was clear on its face. ${ }^{103}$ In contrast, the pragmatic textualists were persistent in stressing not only the importance of the intrinsic record, but also the necessity of extrinsic evidence in claim interpretation. As a normative matter for the pragmatic textualist, a threshold finding of textual ambiguity is not necessary, or even possible, before considering extrinsic evidence. Therefore, like Arthur Corbin ${ }^{104}$ and his student Karl Llewellyn, ${ }^{105}$ the pragmatic textualist would always admit extrinsic

addressing hypertextualism on its own terms.

102. See, e.g., Phonometrics, Inc. v. N. Telecom, Inc., 133 F.3d 1459, 1464 (Fed. Cir. 1998) ("Claim construction is a question of law, and therefore we review the district court's claim interpretation de novo.").

103. One may argue that the text of the patent may have been facially clear or the technology at issue was relatively simple, and therefore extrinsic evidence was not needed. But what may seem plain or simple to a judge may actually be understood as more complex by an artisan. We just don't know. As Judge Easterbrook noted, "[w]hat seems clear to a judge may read otherwise to a skilled designer." In re Mahurkar Double Lumen Hemodialysis Catheter Patent Litig., 831 F. Supp. 1354, 1359 (N.D. Ill. 1993) (Easterbrook, J., sitting by designation).

104. See CORBIN, supra note 86, §555, at 239 (stating that "usages and customs are a part of those circumstances by which the meaning of words is to be judged"); see also Michaels, supra note 21, at 27 ("[W]here the Restatement admits extrinsic evidence only in the case of an ambiguity in the contract itself, Corbin would have required no such prima facie ambiguity. He insisted rather that ambiguity is itself a product of extrinsic evidence, and so would have allowed extrinsic evidence at all times so long as it was for the purpose of interpretation and not contradiction.").

105. See Ross \& Tranen, supra note 86, at 228 ("Llewellyn, in particular, successfully advocated the enforcement of contracts with a minimum number of agreed-upon terms, at the same time that he and others were liberalizing the parol evidence rule to facilitate the admission of extrinsic evidence to prove that the parties 
evidence when construing claim language. ${ }^{106}$ Arguably, from an epistemological perspective, Llewellyn's merchant juror is to commercial law what a PHOSITA is to patent law. ${ }^{107}$

Furthermore, the pragmatic textualists asserted that the characterization of claim interpretation as a question of law is artificial; if forced to affix a label, claim interpretation is a mixed question of law and fact. Therefore, they pushed for a bifurcated standard of review, whereby the district court's factual findings would be reviewed deferentially, and the ultimate decision on claim scope would be subject to de novo review. Needless to say, the hypertextualists, to put it mildly, resisted this line of reasoning, and an ideological struggle ensued.

actually had a 'meeting of the minds' on the relevant issue.").

106. See, e.g., Cybor Corp. v. FAS Techs., Inc., 138 F.3d 1448, 1481 (Fed. Cir. 1998) (en banc) (Newman, J., joined by Judge Mayer, dissenting) ("Of course the primary source of information concerning the claimed invention is the patent documents. But such documents are directed to persons knowledgeable in the field; additional evidence and expert testimony as to their meaning should be the rule, not the exception. So-called 'extrinsic' evidence . . . should be treated like any other evidence, and received and given weight and value as appropriate."); Eastman Kodak Co. v. Goodyear Tire \& Rubber Co., 114 F.3d 1547, 1555 (Fed. Cir. 1997) (Rader, J., joined by Judge Mayer) (stating that "the testimony of one skilled in the art about the meaning of claim terms at the time of the invention will almost always qualify as relevant evidence"), abrogated on other grounds by Cybor, 138 F.3d at 1456; see also Fromson v. Anitec Printing Plates, Inc., 132 F.3d 1437 (Fed. Cir. 1997) (Newman, J., joined by Judges Mayer and Rader) (discussing the importance of extrinsic evidence), abrogated on other grounds by Cybor, 138 F.3d at 1456.

107. See Revised Uniform Sales Act $\S 59$ (1941). See generally Clayton P. Gillette, Courts, Covenants, and Communities, 61 U. CHI. L. Rev. 1375, 1420 (1994) ("Llewellyn's endorsement of merchant juries in commercial cases, for instance, was largely motivated by his sense that merchants alone would be sufficiently familiar with the specialized use of language and practice in commercial contracts to render verdicts that accurately recited the intentions of the parties."); Dennis M. Patterson, Good Faith, Lender Liability, and Discretionary Acceleration: Of Llewellyn, Wittgenstein, and the Uniform Commercial Code, 68 TEX. L. Rev. 169, 208 n.229 (1989) ("Llewellyn's position on the merchant jury is fundamentally epistemological: he thought laypersons were incapable of judging the reasonableness of commercial practices."); Zipporah Batshaw Wiseman, The Limits of Vision: Karl Llewellyn and the Merchant Rules, 100 HARV. L. REV. 465, 512-13 (1987) (discussing rationale behind merchant jury). 
There are several cases representative of the hypertextualist ${ }^{108}$ and pragmatic textualist ${ }^{109}$ positions, but I need only discuss one from each camp and then the culminant case that, for now, added resolution.

The first and perhaps most significant hypertextualist case after Markman II was Vitronics, ${ }^{10}$ briefly discussed above. The Federal Circuit, holding that the district court erred in considering expert testimony in the face of an "unambiguous" intrinsic record, reaffirmed the majority's position in Markman I. The invention in Vitronics related to a method of soldering electrical devices to printed circuit boards. The disputed claim term was "solder reflow temperature." Vitronics argued that this term meant "peak reflow temperature" (i.e., a temperature 20 degrees higher than liquidus temperature) at which the solder is melted and moves freely while Conceptronic asserted that the term meant liquidus temperature, the same temperature at which solder begins to melt. ${ }^{111}$ The district court heard expert testimony from persons of ordinary skill in the art and agreed with those experts who testified that solder reflow temperature and liquidus temperature were used interchangeably. ${ }^{112}$

The Federal Circuit panel, comprised of Judges Michel, Lourie, and Friedman, reversed the district court judge because "the claim, read in light of the patent specification, clearly uses the term 'solder reflow temperature' to mean the peak reflow temperature, rather than the liquidus temperature, [and] that should have been the end of the trial court's analysis." 113 According to the court, extrinsic evidence could be used to construe claim language "[o]nly if there [is] still some genuine ambiguity in the claims, after consideration of all available intrinsic evidence." 114 Although "[n]o doubt there will be instances in which intrinsic evidence is insufficient to enable the court to determine the meaning" of the claims, "[s]uch instances will rarely, if ever, occur." 115 And, "[e]ven in those rare instances, prior art documents and

108. See Bell \& Howell Document Mgmt. Prods. Co. v. Altek Sys., 132 F.3d 701 (Fed. Cir. 1997); Vitronics Corp. v. Conceptronic, Inc., 90 F.3d 1576 (Fed. Cir. 1996).

109. See Metaullics Sys. Co. v. Cooper, 100 F.3d 938 (Fed. Cir. 1996); J.T. Eaton \& Co. v. Atlantic Paste \& Glue Co., 106 F.3d 1563 (Fed. Cir. 1996); see also Eastman Kodak Co. v. Goodyear Tire \& Rubber Co., 114 F.3d 1547 (Fed. Cir. 1997); Fromson v. Anitec Printing Plates, Inc., 132 F.3d 1437 (Fed. Cir. 1997).

110. 90 F.3d 1576 (Fed. Cir. 1996).

111. Id. at $1579-80$.

112. See id. at 1585 .

113. Id. at 1584 .

114. Id. For a discussion of the shortcomings of the Vitronics "ambiguity requirement," see supra text accompanying notes 80-89.

115. Id. at $1584-85$. 
dictionaries . . . are to be preferred over opinion testimony," which "should be treated with the utmost caution, for it is no better than opinion testimony on the meaning of statutory terms." 116

The pragmatic textualists appeared to be emboldened by Vitronics. In a series of opinions, the pragmatic textualists raised the stakes by thrusting the issues of extrinsic evidence and standard of review onto center stage. Of these cases, Fromson v. Anitec Printing Plates, Inc. ${ }^{117}$ is representative. The invention in Fromson pertained to a process for anodizing aluminum, and the disputed claim term was "anodized." 118 The district court interpreted "anodized" based not only on a reading of the intrinsic evidence, but also "on findings based on extrinsic evidence derived from expert testimony, demonstrative evidence, and scientific tests." 119 Fromson, the appellant, citing Markman I, asserted that the claim term "anodized" had a plain meaning; therefore, the district court's relianceon extrinsic evidence was improper. ${ }^{120}$ Judge Newman, joined by Judges Mayer and Plager, disagreed.

In her claim interpretation analysis, Judge Newman did not make a threshold determination of intrinsic ambiguity before considering extrinsic evidence. Rather, the intrinsic and extrinsic evidence were treated as equals. As such, Fromson challenged both Vitronics and Markman I. ${ }^{121}$ According to Judge Newman:

Although Markman [I] presents a useful general rule, it is adaptable to the needs of the particular case. In this case the technical experts not only aided the court's understanding of the technology, but they also provided evidence material to the interpretation of the claims .... .

116. Id. at 1585 .

117. 132 F.3d 1437 (Fed. Cir. 1997).

118. See id. at 1441

119. Id. at 1442 .

120. Id. at 1444 .

121. Recall, Markman I is less permissive than Vitronics with respect to the proper use of extrinsic evidence. Whereas Vitronics permits the court to use extrinsic evidence to construe claims when the intrinsic evidence is ambiguous, Markman I stated that "[i]t is not ambiguity in the document that creates the need for extrinsic evidence but rather unfamiliarity of the court with the terminology of the art to which the patent is addressed." Markman v. Westview Instruments, Inc., 52 F.3d 967, 986 (Fed. Cir. 1995). 
... This case illustrates the use of extrinsic evidence in order to determine the meaning and scope of a technical term as the term is used in the claims. ${ }^{122}$

Another interesting aspect of Fromson pertains to the issue of standard of review. Although Judge Newman made no mention of this issue, Judge Mayer wrote a concurrence, wherein, after emphasizing the importance of expert testimony, ${ }^{123}$ he stated, "We are affirming [the district court judge's] claim construction as a matter of law based on the facts he found from conflicting evidence, which are not clearly erroneous." ${ }^{24}$ Thus, in Fromson the majority treated extrinsic and intrinsic evidence as equally important interpretive tools; in fact, the concurrence explicitly suggested a standard of review directly at odds with Markman I.

In the end, the Federal Circuit had no choice but to address en banc the issue of extrinsic evidence and the proper allocation of interpretive authority. In Cybor Corp. v. FAS Technologies, Inc., ${ }^{125}$ the views of the hypertextualists and pragmatic textualists found full expression, but, when the dust settled, the former carried the day. The majority addressed the pragmatic textualists' reliance on Markman II's language that suggested claim interpretation is a mixed question of law and fact, ${ }^{126}$ stating that these "characterizations . . . are only prefatory comments demonstrating the Supreme Court's recognition" that the

122. Fromson, 132 F.3d at 1444.

123. Judge Mayer began his opinion by noting that Federal Rule of Evidence 702 says that "expert testimony and evidence is [sic] admissible not only to educate but also to find facts." Id. at 1447. Thereafter, Judge Mayer noted that:

I am neither an expert in the field nor one of ordinary skill in the art despite how much I think I "know" about a process I once studied. Nor do my colleagues on this court or on the district court possess such expertise, and even if they did, they would have to defer to the record made in the case. The trial judge performed his Daubert duty and allowed expert testimony and other evidence, not only so that he might become better educated about the meaning of anodization, but also so that he might develop the record and find the meaning of anodization, as used in this patent, to one skilled in the art in 1973 [when the original patent application was filed].

Id. at 1448 .

124. Id. at 1448 .

125. 138 F.3d 1448 (Fed. Cir. 1998) (en banc).

126. See Markman v. Westview Instruments, Inc., 517 U.S. 370, 378, 388 (1996) (stating that claim interpretation is a "mongrel practice" that "falls somewhere between a pristine legal standard and a simple historical fact"). 
law/fact issue "is not simple or clear cut."127 The court insisted that nothing in Markman II "supports the view that the Court endorsed a silent, third option - that claim construction may involve subsidiary or underlying questions of fact." ${ }^{28}$ Indeed, Markman II understood the importance of the Federal Circuit's role in "providing national uniformity to the construction of a patent claim . . ." 129 Moreover, the Supreme Court's silence on the standard of review was in fact an implicit affirmation of Markman I's holding that claim interpretation is subject to de novo review. ${ }^{130}$

Judges Plager and Bryson each wrote a concurring opinion. Both opinions, while endorsing a de novo standard of review, shied away from the law/fact distinction and adopted more of a process approach. Judge Plager wrote:

On appeal, this court has the benefit of the trial judge's considered view, and the record of the effort made at trial to assist the judge in understanding the terms of the claim. Though we review that record "de novo," meaning without applying a formally deferential standard of review, common sense dictates that the trial judge's view will carry weight. ${ }^{131}$

Similarly, Judge Bryson opined, "[W]e approach the legal issue of claim construction recognizing that with respect to certain aspects of the task, the district court may be better situated than we are, and that as to those aspects we should be cautious about substituting our judgment for that of the district court." $" 132$

One gets the impression from reading these concurring opinions that Judges Plager and Bryson are uncomfortable with the characterization of claim construction as one of law. ${ }^{133}$ Although they

127. Cybor, 138 F.3d at 1455 .

128. Id.

129. Id.

130. See id. at 1456

131. Id. at 1462. Judge Plager also showed signs of joining the pragmatic textualist camp when he joined Judge Rader's "additional views" in Pitney Bowes, Inc. v. HewlettPackard Co., 182 F.3d 1298, 1313-15.

132. Cybor, 138 F.3d at 1463 (Bryson, J., concurring).

133. "This court's decision in Markman I, reaffirmed today, simply means that we do not spend our and appellate counsels' time debating whether the trial court's information base constitutes findings of 'fact' or conclusions of 'law, with verbally different standards of review. Instead, both they and we can focus on the question that the trial court addressed, the question that counts: what do the claims mean?" Id. at 
both embrace de novo review, they would employ an institutional competence analysis depending upon the nature of the evidence considered by the district court. These concurrences are important because they try to reconcile de novo review with the institutional superiority of the district court judge with respect to underlying factual determinations. When one looks closely enough, they do not diverge significantly from the position of the pragmatic textualists.

In three separate opinions, the pragmatic textualists, as expected, took a more pronounced position against the majority. Judge Mayer concurred in the judgment and filed an opinion that was joined by Judge Newman. Judge Rader dissented in part, joined in part, and concurred in the judgment, and Judge Newman filed "additional views" with which Judge Mayer joined.

In his opinion, Judge Mayer reiterated much of what he set forth in Metaullics ${ }^{134}$ and $C V I / B E T A^{135}$ and criticized the majority for "profoundly misapprend[ing]" Markman II. ${ }^{136}$ First, he asserted that the Supreme Court did not affirm Markman I's formulation of claim construction as a question of law subject to de novo review. Rather, the analysis in Markman II was largely focused on the Seventh Amendment issue and the role of the jury in claim construction. The Supreme Court, in holding that claim construction was solely for the judge, said nothing about the proper standard of review. ${ }^{137}$ Therefore, it is incorrect to read Markman II as an affirmation of Markman I's characterization of claim interpretation as a question of law reviewed de novo. Second, "without the benefit of a full record from the trial court, it is neither the function of this court nor is it within our capacity as an appellate court to adopt new interpretations"; to do so "deprives the parties of important substantive and procedural mechanisms provided in the trial courts" and "would transform this court into a trial court of first and usually last resort."138

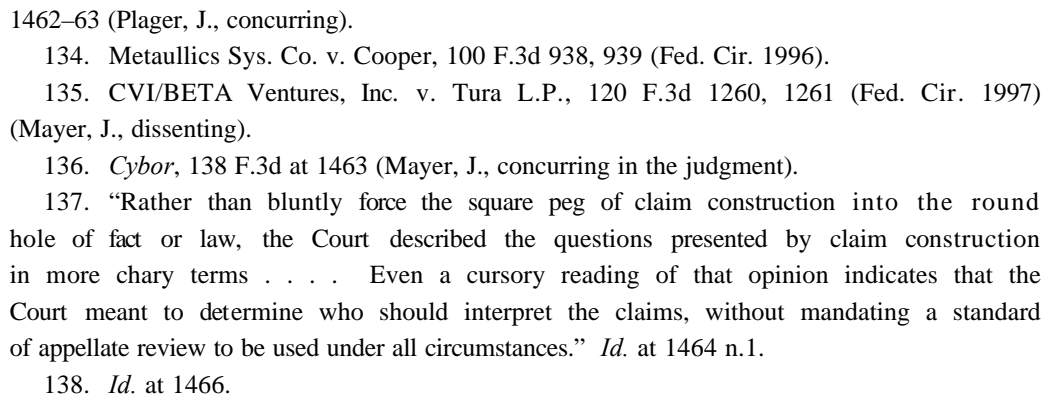


Judge Rader's opinion arguably established him as the leading voice of pragmatic textualism on the court. He argued that the virtue of Markman $I$ is that it eliminated the jury's susceptible and capricious voice from claim interpretation and thereby "promised to improve the predictability and uniformity of patent law."139 The Cybor majority, however, by taking the additional step of characterizing claim construction as a question of law subject to de novo review "will undermine, if not destroy," the promise of Markman I and $I I .{ }^{140}$ Thus, Judge Rader turned the tables on the majority: whereas the majority cited certainty and predictability as justifications for its holding, Judge Rader posited that the holding in Cybor was a portent of quite the opposite.

In support of this proposition, Judge Rader devoted a significant portion of his opinion to discussing the district court's institutional superiority with respect to claim interpretation. This approach should not come as a surprise because Judge Rader has, on at least two occasions, sat by designation as a district court judge in patent infringement proceedings. ${ }^{141}$ This experience undoubtedly influenced his perspective on the proper allocation of interpretive authority concerning the issue of claim construction. Judge Rader focused on the "functional approach" of Markman II and asserted that a similar approach "might best clarify the roles of the trial and appellate benches during claim interpretation." 142 According to Judge Rader, a judge's goal "is to discern the meaning of the claim terms to one of ordinary skill in the art at the time of invention." 43 Therefore, "claim construction requires assessment of custom and usage in the relevant art" and an "assessment of the understanding of skilled artisans at the time of invention." 144 Emphasis on "custom and usage" does not mean that the extrinsic record can contradict or be inconsistent with the

139. Id. at 1473 .

140. Id. at 1474 (Rader, J., dissenting in part, joining in part, concurring in the judgment).

141. See Loral Fairchild Corp. v. Victor Co. of Japan, 931 F.Supp. 1014 (E.D.N.Y. 1996) (Rader, J., sitting by designation); Ristvedt-Johnson, Inc. v. Brandt, Inc., 805 F. Supp. 557 (N.D. Ill. 1992) (Rader, J., sitting by designation).

142. Cybor, 138 F.3d at 1477 (Rader, J., dissenting in part, joining in part, concurring in the judgment).

143. Id. at 1475. As Judge Newman succinctly put it, "patent documents are written by and for persons in the field of the invention, not for judges." Id. at 1480 (Newman, J., additional views).

144. Id. at 1478 (Rader, J., dissenting in part, joining in part, concurring in the judgment). 
intrinsic record. Rather, it means that testimony from a PHOSITA should be embraced and given appropriate weight. ${ }^{145}$ With that in mind, "the trial judge enjoys a potentially superior position to engage in claim interpretation" 146 because

[t]rial judges can spend hundreds of hours reading and rereading all kinds of source material, receiving tutorials on technology from leading scientists, formally questioning technical experts and testing their understanding against that of various experts, examining on site the operation of the principles of the claimed invention, and deliberating over the meaning of the claim language. ... An appellate court has none of these advantages. ${ }^{147}$

Concomitant to the institutional advantage a district court judge enjoys with respect to expert testimony, there is a temporal benefit. That is, greater deference to the district court will lead to early certainty and resolution of claim scope, which in turn may induce early settlement. ${ }^{148}$ According to Judge Rader, a de novo standard of review discourages parties from settling because they are fully aware that there is a good chance that the Federal Circuit will reverse the district court's claim construction. ${ }^{149}$ Thus, the Cybor majority's reading of Markman

145. Judge Rader is careful to remain faithful to the intrinsic record. For example, he states "this relevant [expert] testimony must not conflict with or attempt to trump contemporaneous intrinsic evidence from the patent document itself." Id. at 1475. This assertion begs the question: At what point does extrinsic evidence stop aiding in understanding claim meaning and start contradicting intrinsic evidence? In my opinion, when the judge, after being assisted by an independent court-appointed expert, will have an understanding of what the claim language means and can determine if the extrinsic evidence is being offered to contradict the claim meaning.

146. Id. at 1477 .

147. Id.

148. See id. at 1475 .

149. See id. at 1475-77. Pointing to empirical evidence, Judge Rader writes:

$[\mathrm{O}]$ ne study shows that the plenary standard of review has produced reversal, in whole or in part, of almost $40 \%$ of all claim constructions since Markman I. A reversal rate in this range reverses more than the work of numerous trial courts; it also reverses the benefits of Markman I. In fact, this reversal rate, hovering near $50 \%$, is the worst possible. Even a rate that was much higher would provide greater certainty.

Id. at 1476 .

These figures were based on a survey of every Federal Circuit decision rendered 
I "means that the trial court's early claim interpretation provides no early certainty at all, but only opens the bidding." 150

Also weighing in against the majority was Judge Newman. Her "additional views" bemoaned the uncertainties brought about by Markman $I$ s de novo review. Judge Newman both endorsed the process considerations emphasized by Judge Rader and focused on the role of the artisan in claim interpretation. With respect to the former, Judge Newman asserted that the majority's holding that claim interpretation does not entail fact-finding amounted to a "fiction." 151 The entire "fact/law theory" of Markman I was an "artificial construct" that created a zero sum game that enhanced the power of the appellate judge at the expense of the trial judge. ${ }^{152}$ In Markman II, the Supreme Court "opened the door" for the Federal Circuit to retreat from this false "fact/law" dichotomy and "did not shut out the trial judge along with the jury." 153

Judge Newman then proceeded to discuss the benefits of expert testimony to claim interpretation. Like Judge Rader, she emphasized that claim meaning must be discerned by asking what a PHOSITA would understand the claim to mean at the time the claim language was drafted. Expert testimony is crucial to this determination, and the majority's constraints on the use of such testimony operate as an "unnecessary bar to enlightenment."

between April 5, 1995 (the date Markman I was decided) and November 24, 1997. The total number of cases was 246, of which 141 expressly reviewed the claim interpretation of the lower tribunal (i.e., district courts, Board of Patent Appeals and Interferences, and the Court of Federal Claims). Of the 141 cases, the Federal Circuit reversed the lower tribunal's claim construction, in whole or in part, "54 [times] or 38.3\%." Id. at 1476 n.4. The appellate court reversed the claim interpretation of the district courts and the Court of Federal Claims " 47 out of 126 [times] or 37.3\%." Id. Furthermore, in a recent public speech, Judge Lourie noted that "district court patent cases have been reversed $18 \%$ in toto and $23 \%$ in part, for a total of $41 \%$ of patent appeals that have produced some benefit to appellant." Judge Alan D. Lourie, Speech to PTC Section of Washington, D.C. Bar (June 12, 2000), in 60 Pat. Trademark \& Copyright J. 147, 148 (2000). Judge Lourie further stated that of the $41 \%$, "27\% were on claim construction." Id. See also TM Patents, L.P. v. Int'l Bus. Machs. Corp., 72 F. Supp. 2d. 370, 377 n.1 (S.D.N.Y. 1999) ("Given the frequency with which the Federal Circuit overrules District Court judges on issues of claim interpretation .. . [interlocutory] appeals would save millions of dollars and thousands of hours of trial time based on patent constructions that turn out to be erroneous.").

150. Cybor., 138 F.3d at 1476.

151. Id. at 1480 .

152. Id.

153. Id. at 1481 .

154. Id. 
in Fromson, ${ }^{155}$ Judge Newman maintained that expert testimony should be considered, regardless of whether ambiguity exists. ${ }^{156}$

Of course the primary source of information concerning the claimed invention is the patent documents. But such documents are directed to persons knowledgeable in the field; additional evidence and expert testimony as to their meaning should be the rule, not the exception. So-called "extrinsic" evidence ... should be treated like any other evidence, and received and given weight and value as appropriate. ${ }^{157}$

Similar to Judge Rader's assertion in Eastman Kodak that "the testimony of one skilled in the art about the meaning of claim terms at the time of the invention will almost always qualify as relevant evidence," ${ }^{158}$ Judge Newman would place expert testimony on equal footing with the intrinsic record. ${ }^{159}$ By considering extrinsic evidence

155. Fromson v. Anitec Printing Plates, Inc., 132 F.3d 1437 (Fed. Cir. 1997), abrogated on other grounds by Cybor Corp. v. FAS Techs., Inc., 138 F.3d 1448, 1456 (Fed. Cir. 1998).

156. Cybor., 138 F.3d at 1480 (Newman, J., additional views) ("The Federal Circuit's ruling that extrinsic evidence must be restricted unless there is a facial ambiguity in the meaning of the claim is an unnecessary restraint on potentially useful evidence.").

157. Id. at 1481 (emphasis added). See also FARNSWORTH, supra note 22, § 7.10, at 512. ("Since the purpose of [contract interpretation] is to ascertain the meaning to be given to the language, there should be no requirement that the language be ambiguous, vague, or otherwise uncertain before the inquiry is undertaken."); Michaels, supra note 21 , at 30 ("For one thing, . . . the decision that a text is ambiguous cannot be made prior to the introduction of extrinsic evidence.").

158. Eastman Kodak Co. v. Goodyear Tire \& Rubber Co., 114 F.3d 1547, 1555 (Fed. Cir. 1997) (emphasis added), abrogated on other grounds by Cybor, 138 F.3d at 1456.

159. In a post-Cybor opinion, Judge Newman, in perhaps her strongest language to date, again stressed the importance of extrinsic evidence:

The panel majority, having rejected the expert testimony adduced at the trial on the ground that it is "extrinsic," excludes itself from access to this evidence and whatever scientific truth it comports.

I believe it is seriously incorrect to foreclose consideration of such "extrinsic" evidence. It is increasingly recognized that courts must be enabled and encouraged to receive and understand the guidance of experts. The scientific witnesses for both sides agreed as to the uncertainties of this chemistry and the ensuing ambiguity of interpretation of the claims in light of the state of the art when the invention was made. This court's refusal to consider the evidence of experts for both sides . . . is not the path to 
before a finding of textual ambiguity, Judges Newman and Rader recognize that plain meaning is a "function[] not of texts but of the situations in which we read them." 160

We should note at this point that two of the three pragmatic textualists agree that extrinsic evidence should be considered irrespective of intrinsic ambiguity. Or stated another way, consideration of extrinsic evidence "should be the rule, not the exception." places on the artisan's role in our patent system, it is plausible, if not probable, that he would subscribe to this approach as well. As Judge Newman noted, "patent documents are written by and for" persons of ordinary skill in the art. ${ }^{162}$ Thus, the understanding and information that experts bring to bear on claim interpretation is as much a part of the public record and is entitled to as much weight as the claims, written description, and prosecution history. Expert testimony, in other words, is actually a part of the intrinsic evidence because artisans of a particular technical community share a common language. ${ }^{163}$ This seems to be eminently sensible and is in accord with contemporary legal and hermeneutic philosophy. ${ }^{164}$ How is a judge to interpret a document if he is not initially permitted to consider the views of the document's intended audience? Markman I's distinction between allowing expert testimony to be used to understand the technology, but not to interpret the claims, is really a distinction without a difference. As Judge Rader aptly noted,

As a matter of logic, this instruction is difficult to grasp. What is the distinction between a trial judge's

enlightenment on the complexities of polymer chemistry and

technology. Judicial doubt cannot be resolved by exclusion of the evidence that explains the scientific issues.

Phillips Petroleum Co. v. Huntsman Polymers Corp., 157 F.3d 866, 878-79 (Fed. Cir. 1998) (Newman, J., concurring in judgment).

160. Michaels, supra note 21 , at 33 ; see also FARNSWORTH, supra note $22, \S 7.10$, at 512-13; E. Allan Farnsworth, "Meaning" in the Law of Contracts, 76 YALE L.J. 939, 957-63 (1967).

161. Cybor, 138 F.3d at 1481 (Newman, J., additional views).

162. Id. at 1480 .

163. Of course, there may be disagreement within a given community; however, the disagreement is confined within community parameters that are acknowledged and understood by members of the community. For a discussion of the approach that should be taken when there is disagreement over a particular claim term, see text accompanying notes $310-46$.

164. See infra text accompanying notes 226-309. 
understanding of the claims and a trial judge's interpretation of the claims to the jury? .... . What happens when that learning influences a trial judge's interpretation of the claim terms? Are trial judges supposed to disguise the real reasons for their interpretation? ${ }^{165}$

With strained reasoning, the hypertextualists are forced to manufacture legal fictions, whether it be characterizing claim interpretation as a pure question of law, requiring a finding of an intrinsic ambiguity before expert testimony can be considered, or permitting the use of expert testimony only as an educational tool. These fictions were devised and are maintained in the name of certainty, uniformity, and predictability. Ironically, the result has been contra ${ }^{166}$ - a result that is antithetical to patent law's incentive dynamic.

\section{Ex Post Innovation Theories}

One of the fundamental distinctions between pragmatic textualism and hypertextualism is that the former's interpretive method is more sensitive to consequences. This consequentialism is not only reflective of American patent law's utilitarian roots, but is also germane to ex post innovation theories. Ex post innovation theories - namely, improvement theory and design-around theory — focus on inducements to artisans to build upon or design around extant patented technology. The manner in which patent claims are interpreted and their resulting scope directly affect the nature of the inducement. ${ }^{167}$

165. Cybor, 138 F.3d at 1474-75 (Rader, J., dissenting in part, joining in part, concurring in the judgment).

166. See William F. Lee and Anita K. Krug, Still Adjusting to Markman: A Prescription for the Timing of Claim Construction Hearings, 13 HARV. J.L. \& TECH. 55, 67 (1999) ("Although, according to the Federal Circuit and the Supreme Court, Markman should have ushered in greater uniformity, predictability, and certainty in patent litigation, many believe that the holding has had the opposite effect. This is largely because Federal Circuit review of claim interpretation is de novo.") In lamenting the "disappointed expectations" of Markman I, Judge Newman has written that the Federal Circuit has engaged in "creative de novo claim interpretations" on appeal. Cybor, 138 F.3d at 1479. According to Judge Newman, "[t]his unpredictability in administration of the law of patent claiming has added a sporting element to our bench." Id. See also supra note 149 , discussing the reversal rate of district court claim interpretations.

167. See infra note 188 . 
Hypertextualism is arguably inconsistent with a viable ex post innovation theory. Whereas the pragmatic textualist appreciates that "meaning depends on both culture and context," 168 the hypertextualist refuses to delve into the linguistic practices of the relevant technological community, choosing instead to excavate the patent text with, at times, Schliemann-like intensity. By denying the expert his say on claim meaning, the hypertextualist ignores the decentralized nature of technical knowledge. ${ }^{169}$ The hypertextualist further ignores the fact that persons of ordinary skill in the art stand upon the shoulders of their predecessors and have a contextual understanding of the relevant technical language.

\section{Improvement Theory}

One of the fundamental policies of patent law is "to promote disclosure of inventions" so as to "stimulate further innovation." 170 Building upon preexisting knowledge is central to efficient technological advancement. ${ }^{171}$ As Edmund Kitch writes, "each innovation generates shifts in the matrix of technological possibilities, and the realization of

168. Cass R. Sunstein, After the Rights Revolution: Reconceiving the Regulatory State 114 (1990); see also George H. Taylor, Structural Textualism, 75 B.U. L. REV. 321, 362-66 (1995).

169. See Friedrich A. Hayek, The Use of Knowledge in Society, 35 AM. Econ. Rev. 519 (1945), reprinted in INDIVIDUALISM AND ECONOMIC ORDER 77-78 (1948):

"[D]ata" from which the economic calculus starts are never for the whole society "given" to a single mind which could work out the implications and can never be so given.

The peculiar character of the problem of a rational economic order is determined precisely by the fact that the knowledge of the circumstances of which we must make use never exists in concentrated or integrated form but solely as the dispersed bits of incomplete and frequently contradictory knowledge which all the separate individuals possess. The economic problem of society is ... . how to secure the best use of resources known to any of the members of society, for ends whose relative importance only these individuals know. Or, to put it briefly, it is a problem of the utilization of knowledge which is not given to anyone in its totality.

170. Aronson v. Quick Point Pencil Co., 440 U.S. 257, 262 (1979).

171. See Richard R. Nelson \& Sidney G. Winter, AN Evolutionary Theory of ECONOMic Change 130 (1982); Robert P. Merges \& Richard R. Nelson, On the Complex Economics of Patent Scope, 90 Colum. L. REv. 839 (1990); Suzanne Scotchmer, Standing on the Shoulders of Giants: Cumulative Research and the Patent Law, 5 J. ECON. PERSP. 29, 30-31 (1991). 
the possibilities may have a significance that dwarfs the original invention considered alone." 172

When we speak of "improvement patents," however, we must keep in mind one of the basic tenets of patent law: one may obtain a patent on a particular invention, yet still infringe an extant patent. Consider the following example:

Inventor 1 patents a widget comprising elements $\mathrm{A}, \mathrm{B}$, and $\mathrm{C}$. Inventor 2 improves upon inventor 1 's invention by adding $\mathrm{D}$, thus giving inventor 2 a patent on a widget comprising elements $\mathrm{A}, \mathrm{B}, \mathrm{C}$, and $\mathrm{D}$ (assume $\mathrm{D}$ is a nonobvious addition to $\mathrm{A}, \mathrm{B}$, and $\mathrm{C}$ ). Although [having a patent,] Inventor 2 cannot practice his invention because Inventor 2's invention contains each and every element (A, B, and C) claimed in Inventor 1 's patent, thus infringing Inventor 1's patent. On the other hand, Inventor 1 cannot practice Inventor 2's invention without the permission of the latter. $^{173}$

What we have in this situation is known in patent law as "blocking patents," a situation that is largely influenced by market forces. At least three things can happen: (1) the parties cross-license each other - a particularly attractive choice if the improvement adds significant value to the original patent; ${ }^{174}(2)$ the parties sell the patents to a third party who will coordinate future development and improvement; or (3) the parties fail to come together for whatever reason (e.g., high transaction costs) and no one (the patentee, the improver or society) enjoys the improvement. ${ }^{175}$

172. Edmund W. Kitch, The Nature and Function of the Patent System, 20 J.L. \& ECON. 265, 271 (1977).

173. Donald S. Chisum et Al., Principles of Patent Law 5, n.16 (1998).

174. See, e.g., Standard Oil Co. v. United States, 283 U.S. 163, 171 n.5 (1931) (referring to cross-licensing, the court stated "[t]his is often the case where patents covering improvements of a basic process, owned by one manufacturer, are granted to another. A patent may be rendered quite useless, or 'blocked,' by another unexpired patent which covers a vitally related feature of the manufacturing process.").

175. See Mark A. Lemley, The Economics of Improvement in Intellectual Property Law, 75 Tex. L. Rev. 989, 1067 n. 350 (1997) ("While it might seem irrational to think that an original inventor would suppress an improvement within her control if it truly was valuable, several circumstances might induce her to do so. If the improvement requires a new manufacturing technology or a different market approach, there may be substantial fixed costs associated with switching over production from the old to the new 
The point to be made here is that the improver has bargaining power in the form of a patented invention. There is a significant difference between being an improver with a patent and an improver without a patent. Without a patent, not only will the improver infringe the extant patent, but he will be unable to preclude others from using his unpatented improvement. On the other hand, a patent, while not allowing the improver to escape liability for infringement, will arm the improver with bargaining power as he is now able to preclude others, including the owner of the infringed patent, from making, using, or selling the improver's invention. Confidence in the validity of the improver's patent is of the utmost importance in this regard. The improver needs to know that when a court interprets the claims in evaluating the validity of his patented improvement, the court will consider the same linguistic customs and underlying assumptions that the improver himself considered when studying the prior art (including a competitor's patent) and when drafting his own patent application.

Let's take a step back and look at the improvement process. There are times when the written description of a patent itself will suggest to an improver a particular idea or experiment that will not infringe the patent. The improver will then proceed with his experimentation without the need to negotiate a license with the original patent owner. However, most of the time the improver must make use of the patented invention in his research, in which case the improver will either have to purchase the patented product on the open market ${ }^{176}$ or obtain a license ex ante from the patent holder to use the patented technology. It is anything but a forgone conclusion that the patent holder will agree to grant the improver a license, especially if the improver poses a commercial threat to the patent holder or the transaction costs are otherwise prohibitively high. ${ }^{177}$ Nevertheless, a court can facilitate ex

way. The further removed the improvement is from the original invention, the worse this problem is likely to be . . . The alternative to switching over production facilities . . . is also unlikely to be attractive to the original inventor. Even if the licensor could extract the full value of the improvement in a licensing transaction, which seems unlikely, its market control will disappear along with the intellectual property right."). For a general discussion of blocking patents, see Robert Merges, Intellectual Property Rights and Bargaining Breakdown: The Case of Blocking Patents, 62 TENN. L. REV. 75 (1994).

176. This conveys an implied license to use the product. See United States v. Univis Lens Co., 316 U.S. 241, 249 (1942).

177. See Rebecca S. Eisenberg, Patents and the Progress of Science: Exclusive Rights and Experimental Use, 56 U. CHI. L. REV. 1017, 1072-74 (1989) ("The risk that the parties will be unable to agree on terms for a license is greatest when subsequent researchers want to use prior inventions to make further progress in the same field in 
ante licensing by employing interpretive analyses that lend themselves to predictability of claim scope and accurate valuation of the improved invention as well as the original patent. ${ }^{178}$ A hypertextualist approach to claim interpretation silences the voices of those who will most likely be significantly involved in negotiating a license. If it is probable that a court will interpret a particular technical term as that term is understood in the industry, then the parties will have a good idea of where the proprietary fence lies as well as the commercial value of the inventions at issue.

However, there is a significant possibility that negotiations will occur ex post. ${ }^{179}$ At this point the claim scope of the original patent becomes crucial because the risks of proceeding with improvement activity are directly affected by the original patent's claim scope. ${ }^{180}$ Several commentators have asserted that a broad construction of the original patent may adversely affect the incentive for improvement activity. ${ }^{181}$ Therefore, in order to encourage the development of improvement patents, the claims of the original patent should be construed narrowly so as not to capture the improvement. Others have argued that incentives should be focused on the original patentee, thus forcing the improver to negotiate a license or forego use of the

competition with the patent holder, especially if the research threatens to render the patented invention technologically obsolete."); see also JOHN W. SCHLICHER, LICENSING INTELLECTUAL PROPERTY 47-48, 86 (1996) ("The primary transaction costs are 1. The information costs of identifying buyers and sellers, and informing buyers of the rights for sale, and 2. The costs of negotiating agreements, performing under them, and detecting and stopping violations."). But see Frank H. Easterbrook, Cyberspace versus Property Law?, 4 TEX. REV. L. \& POL. 85, 111 (1999) (asserting that technology is reducing the cost of bargaining).

178. Cf. Robert P. Merges, Contracting into Liability Rules: Intellectual Property Rights and Collective Rights Organizations, 84 CAL. L. REV. 1293 (1996) (discussing cross-licensing and cooperative arrangements in various technological fields).

179. See John H. Barton, Patents and Antitrust: A Rethinking in Light of Patent Breadth and Sequential Innovation, 65 ANTITRUST L.J. 449, 453 (1997) ("[I]t seems likely that many actual improvement invention situations will be, at least in part, ex post, for the improvement inventors will often independently gain the key insight looking to an improvement and then have to invest significantly in understanding its implications before they can knowledgeably negotiate with the initial inventor. Thus, the second firm's investment decisions must be tempered by the risk that the negotiation will not turn out well.").

180. See, e.g., Scotchmer, supra note 171; Jerry R. Green \& Suzanne Scotchmer, On the Division of Profit in Sequential Innovation, 26 RAND J. ECON. 20 (1995); Howard F. Chang, Patent Scope, Antitrust Policy, and Cumulative Innovation, 26 RAND J. ECON. 34 (1995); Merges \& Nelson, supra note 171; Kitch, supra note 172.

181. See, e.g., Merges \& Nelson, supra note 171; Barton, supra note 179. 
invention. ${ }^{182}$ The point I wish to make here is not that the original patent should be construed broadly or narrowly. Rather, I assert that a court must be sensitive to the issue of claim scope and have an intimate (or as intimate as possible) understanding of the respective contributions to the art in question in order to properly balance the incentives of the original patentee with those of the improver. Unlike pragmatic textualism with its emphasis on context and consequences, ${ }^{183}$ hypertextualism fosters a disconnect between claim interpretation and industry practices, thus enhancing the likelihood of misreading and misjudging the incentive dynamic.

With that said, the would-be improver may channel his inventive energies elsewhere when licensing negotiations break down or the risks associated with improvement activity are too great. ${ }^{184}$ One alternative is for the improver to "design-around" the patented invention in an attempt to avoid infringement altogether.

\section{Design-Around Theory}

We know that sometimes the parties simply cannot come to terms during licensing negotiations and improvement activity may prove too risky. Faced with the uninviting choice between the high transaction costs associated with licensing and the high costs of litigation, the competitor may opt to "design-around" the patented technology. As the term "design-around" suggests, a competitor of the patentee may purposefully circumvent the boundaries of the patent claim and create a competitive, non-infringing alternative to the claimed invention. The practice of designing-around extant patents creates viable substitutes and advances, resulting in competition among patented technologies. ${ }^{185}$

182. See, e.g., Suzanne Scotchmer, Protecting Early Innovators: Should SecondGeneration Products Be Patentable?, 27 RAND J. ECON. 322 (1996); Green \& Scotchmer, supra note 180.

183. See Posner, supra note 1, at 19 ("Pragmatists want the law to be more empirical, more realistic, more attuned to the real needs of real people.").

184. This is not to say that the improver may not proceed in his experimentation without a license, particularly if the improver was confident that he could patent the improvement and thus better position himself at the bargaining table with the original patentee. See Eisenberg, supra note 177, at 1044 ("Some subsequent researchers might find it worthwhile to improve a patented invention even without a license if the improvement itself were patentable.").

185. Several economists and courts have asserted that a patent grant does not necessarily translate into monopolistic market power. See HERBERT HovenKAMP, ECONOMIC AND FEDERAL ANTITRUST LAW 156, 219 (1985) ("[A] patented product . . . may compete intensely with similar products which are either unpatented or covered 
The public clearly benefits from such activity. ${ }^{186}$ As the Federal Circuit recently stated, "[o]ne of the benefits of a patent system is its so-called 'negative incentive' to 'design around' a competitor's products, even when they are patented, thus bringing a steady flow of innovations to the marketplace." 187

To design-around a patent claim, the competitor must know with some particularity and certainty where the patentee's proprietary interest begins and ends so as to allow the competitor to produce a viable

by different patents... More often than not the patent... makes a product 'distinguishable' but confers little or no measurable market power upon its owner."); F.M. Scherer, Industrial Market Structure and Economic Performance 446 (2d ed. 1980) (" $[F]$ ew patents are sufficiently basic and broad to 'fence in' a field altogether.”). See also Justice O'Connor's concurring opinion in Jefferson Parish Hospital District No. 2 v. Hyde, 466 U.S. 2 (1984), wherein she rejected the majority's presumption that a patent or copyright leads to market power:

A common misperception has been that a patent or copyright.

. suffices to demonstrate market power. While ... [this factor] might help to give market power to a seller, it is also possible that a seller in these situations will have no market power: for example, a patent holder has no market power in any relevant sense if there are close substitutes for the patented product.

Id. at 37, n.7 (O'Connor, J., concurring in the judgment); Abbott Labs. v. Brennan, 952 F.2d 1346, 1354 (Fed. Cir. 1991) ("[a] patent does not of itself establish a presumption of market power in the antitrust sense."); Chiuminatta Concrete Concepts, Inc. v. Target Prods., Inc., No. CV 92-1523-LGB, 1992 WL 465720 (C.D. Cal. Dec. 2, 1992), aff'd mem., 19 F.3d 41 (Fed. Cir. 1994). Of course, there are occasions where a patent, particularly a pharmaceutical patent, in and of itself confers monopolistic market power.

186. See Slimfold Mfg. Co. v. Kinkead Indus., Inc., 932 F.2d 1453, 1457 (Fed. Cir. 1991) ("Designing around patents is . . . one of the ways in which the patent system works to the advantage of the public in promoting progress in the useful arts, its constitutional purpose.").

187. State Indus., Inc. v. A.O. Smith Corp., 751 F.2d 1226, 1236 (Fed. Cir. 1985); see also Hilton Davis Chem. Co. v. Warner-Jenkinson Co., 62 F.3d 1512, 1520 (Fed. Cir. 1995) ("The ability of the public successfully to design around - to use the patent disclosure to design a product or process that does not infringe, but like the claimed invention, is an improvement over the prior art - is one of the important public benefits that justify awarding the patent owner exclusive rights to his invention."), rev'd, 520 U.S. 17 (1997); In re Alappat, 33 F.3d 1526, 1553 (Fed. Cir. 1994) ("Even after a patent has been awarded for a new, useful, and nonobvious practical application of an idea, others may learn from the underlying ideas, theories, and principles to legitimately 'design around' the patentee's useful application."); Yarway Corp. v. EurControl USA, Inc., 775 F.2d 268, 277 (Fed. Cir. 1985). But see SCHERER, supra note 185 , at 446 (arguing that resources used in designing around patents could be put to better use); Donald F. Turner, The Patent System and Competitive Policy, 44 N.Y.U. L. REV. 450, 455 (1969). 
alternative without being subjected to an infringement suit. ${ }^{188}$ For this to happen, however, competitors must have confidence in the court's ability to understand how the claim language that is purposely being circumvented is used and understood in the relevant technological community. Although a hypertextualist approach with its emphasis on textual fidelity may seem ideal to fostering such confidence, upon closer analysis hypertextualism can just as likely lead to misconceived and costly innovation decisions. As Judge Newman has written:

Patent law is practiced mainly through legaladvice and counseling over the course of the commitment of creative and capital resources, to manage legal risk in the already risky business of industrial innovation. Like all commercial law, the cost of guessing wrong about the law and its application is rarely recoverable. ${ }^{189}$

Because "[p]atent law is practiced mainly through legal advice," it is common practice for a competitor, wishing to design-around a claimed invention, to secure a "noninfringement opinion" from patent counsel before making or using the design-around product. This opinion is based on a study of the patent claims, prosecution history, the prior art, and the competitor's design-around product. ${ }^{190}$

188. See London v. Carson Pirie Scott \& Co., 946 F.2d 1534, 1538 (Fed. Cir. 1991) ('[C]laims must be 'particular' and 'distinct,' as required by 35 U.S.C. $\S 112$, so that the public has fair notice of what the patentee and the Patent and Trademark Office have agreed constitute the metes and bounds of the claimed invention. Notice permits other parties to avoid actions which infringe the patent and to design around the patent.").

189. Pauline Newman, The Federal Circuit: Judicial Stability or Judicial Activism?, 42 AM. U. L. REv. 683, 687 (1993); see also Read Corp. v. Portec, Inc., 970 F.2d 816, 828 (Fed. Cir. 1992) ("Of course, determining when a patented device has been 'designed around' enough to avoid infringement is a difficult determination to make. One cannot know for certain that changes are sufficient to avoid infringement until a judge or a jury has made that determination."), abrogated by Markman v. Westview Instuments, Inc., 52 F.3d 967, 975 (Fed. Cir. 1995) (en banc).

190. See Jurgens v. CBK, Ltd., 80 F.3d 1566, 1572 (Fed. Cir. 1996) ("The steps 'normally considered to be necessary and proper in preparing an opinion' include a thorough review of the cited prior art and prosecution history."); Underwater Devices, Inc. v. Morrison-Knudsen Co., 717 F.2d 1380, 1390 (Fed. Cir. 1983) ("Had [the infringement opinion] contained within its four corners a patent validity analysis, properly and explicitly predicated on a review of the file histories of the patents at issue, and an infringement analysis that, inter alia, compared and contrasted the potentially infringing method or apparatus with the patented inventions, the opinion may have contained sufficient internal indicia of credibility to remove any doubt that 
Importantly, because "counsel's opinion must be thorough enough . . . to instill a belief in the infringer that a court might reasonably hold the patent is invalid, not infringed, or unenforceable," 191 the attorney writing the opinion must consult with the inventor or other artisans so as to comprehend fully the technology and technical terms at issue. Thus, the opinion is frequently a joint product of the attorney and the artisan.

This reality highlights the artificial nature of hypertextualism and its broad constraints on the use of extrinsic evidence. Whereas the author of the "noninfringement opinion" seeks advice from persons of ordinary skill in the art, the hypertextualist judge remains within the proverbial four corners of the text. ${ }^{192}$ If the Federal Circuit $w$ hear from the artisan, how is it that the court expects alleged infringers, based on opinion of counsel, to have a good faith belief that the "court might reasonably hold the patent . . invalid, not infringed, or unenforceable?"193

\section{Pragmatic textualism: Through the Eyes OF AN ARTISAN}

\section{A. Extrinsic Context and the Role of Underlying Assumptions}

In Markman $I$, the hypertextualist majority eschewed expert testimony as an interpretive tool and established a de novo standard of review of a district court's claim interpretation because

it is only fair (and statutorily required) that competitors be able to ascertain to a reasonable degree the scope of the patentee's right to exclude . . . . They may understand what is the scope of the patent owner's rights by obtaining the patent and prosecution history - "the undisputed public record," — and applying established rules of construction to the

M-K in fact received a competent opinion.").

191. Ortho Pharm. Corp. v. Smith, 959 F.2d 936, 944 (Fed. Cir. 1992); see also Jurgens, 80 F.3d at 1572.

192. Yet, a hypertextualist judge will criticize the alleged infringer for not communicating with the attorney regarding issues of the relevant technology, validity, and infringement. See Amsted Indus. Inc. v. Buckeye Steel Castings Co., 24 F.3d 178, 182-83 (Fed. Cir. 1994) (Lourie, J.).

193. Ortho Pharm., 959 F.2d at 944. 
language of the patent claim in the context of the patent. Moreover, competitors should be able to rest assured, if infringement litigation occurs, that a judge, trained in the law, will similarly analyze the text of the patent and its associated public record and apply the established rules of construction, and in that way arrive at the true and consistent scope of the patent owner's rights to be given legal effect. ${ }^{194}$

The hypertextualists are indeed correct when they argue that a patent applicant is "statutorily required" under 35 U.S.C. § 112, If 2 to claim with particularity where his proprietary interest resides. This section of the patent code, much like the written description requirement of the nineteenth century, ${ }^{195}$ seeks to impose certainty and predictability on the patent system. However, § 112, If 2 cannot be read in isolation or in an overly literal fashion because to focus solely on the claim language when interpreting a claim is to adopt an acontextual "plain meaning" approach to claim interpretation. The plain meaning rule, whether applied in interpreting statutes or claims, has been widely discredited, and its shortcomings extensively recounted. ${ }^{196}$

194. Markman v. Westview Instruments, Inc., 52 F.3d 967, 978-79 (emphasis added).

195. See supra note 50.

196. See, e.g., Richard A. Posner, The Problems of Jurisprudence 296 (1990) ("[T]he central objection of the plain-meaning rule [is] meaning does not reside simply in the words of a text, for the words are always pointing to something outside."); 2 A Norman J. Singer, Sutherland on Statutes and Statutory CONSTRUCTION $\S 46.02$, at 91-92 (5th ed. 1992) ("The absence of intrinsic meanings in language is an insight of semantics that has come to be widely understood and accepted ... I It is pertinent to recall the semantic insight that language symbols do not have intrinsic meanings, independent of contextual considerations which influence what people attribute to them. Even when a judge claims not to be construing a statute, he can not help using what he has learned about customary language usage and common understanding associated with the relevant text."); William N. Eskridge, Jr. \& Phillip P. Frickey, Statutory Interpretation As Practical Reasoning, 42 Stan. L. Rev. 321, 343 (1990); Cass R. Sunstein, Interpreting Statutes in the Regulatory State, 103 HARV. L. REV. 405, 416-23 (1989) (discussing generally the critiques of the plain-meaning rule); Taylor, supra note 168, at 362; Patterson, supra note 107, at 188 ("In the present era of preoccupation with language, it is perhaps difficult to conceive how anyone could ever have viewed language as enjoying plain meaning."); Stanley Fish, Almost Pragmatism: Richard Posner's Jurisprudence, 57 U. CHI. L. REv. 1447, 1456 (1990) ("No act of reading can stop at the plain meaning of a document, because that meaning itself will have emerged in the light of some stipulation of intentional circumstances, of purpose held by agents situated in real word situations."); Arthur L. Corbin, The Interpretation of Words and the Parol Evidence Rule, 50 CORNELL L.Q. 161, 164 
Because "[c]laims cannot be clear and unambiguous on their face," ${ }^{197}$ the Federal Circuit has stated that claims must be read "in the context of the patent." ${ }^{198}$ It is over the interpretation of this battleground phrase - "in the context of the patent" - that hypertextualists and pragmatic textualists part company. When construing claim language, each camp examines the textual interrelationship among the claims, written description, and prosecution history, and each attaches varying degrees of emphasis to dictionaries. ${ }^{199}$ Indeed, this structural analysis of the intrinsic record is essential to claim construction. ${ }^{200}$ However, the hypertextualists limit their interpretive analysis to the intrinsic context because the patentee's "competitors are entitled to rely on the public record of the patent." 201 Pragmatic textualists certainly agree with this proposition, but they have a broader view of the public record. They not only engage in a structural analysis of the intrinsic evidence, but also consider as equally authoritative the extrinsic context - namely, the underlying linguistic assumptions of the relevant technological community.

(1950) ("[N]o man can determine the meaning of written words by merely glueing his eyes with the four corners of a square paper.").

197. Autogiro Co. of Am. v. United States, 384 F.2d 391, 396 (Ct. Cl. 1967).

198. Markman, 52 F.3d at 979.

199. The hypertextualists prefer a dictionary to expert testimony because a dictionary is "accessible to the public in advance of litigation... . [Therefore a dictionary is] to be preferred over opinion testimony, whether by an attorney or artisan in the field of technology to which the patent is directed." Vitronics Corp. v. Conceptronic, Inc., 90 F.3d 1576, 1585 (Fed. Cir. 1996). In contrast, the pragmatic textualists view a dictionary definition as "secondary to the specific meaning of a technical term as it is used and understood in a particular technical field." Hoechst Celanese Corp. v. BP Chems. Ltd., 78 F.3d 1575, 1580 (Fed. Cir. 1996) (Newman, J.); see also Toro Co. v. White Consol. Indus., Inc., 199 F.3d 1295, 1299 (Fed. Cir. 1999) (Newman, J.) ("In judicial 'claim construction' the court must achieve the same understanding of the patent, as a document whose meaning and scope have legal consequences, as would a person experienced in the technology of the invention. Such a person would not rely solely on a dictionary of general linguistic usage, but would understand the claims in light of the specification and the prior art, guided by the prosecution history and experience in the technologic field."); cf. Cabell v. Markham, 148 F.2d 737, 739 (2d Cir. 1945) (Hand, J.) (asserting that "it is one of the surest indexes of a mature and developed jurisprudence not to make a fortress out of the dictionary.").

200. See Taylor, supra note 168 , at 362 ("Structural textualism acknowledges that words gain their meaning on the basis of their interrelations with the rest of the text.").

201. Key Pharms. v. Hercon Labs. Corp., 161 F.3d 709, 716-17 (Fed. Cir. 1998). Interestingly, hypertextualists quickly point to section 112, If 2 of the patent code to support their position, yet ignore this section and other parts of the code that speak to the central role of the artisan - i.e., sections 103 and 112, q 1. 
Thus, while the intrinsic context forms the structural interpretive foundation, contemporary hermeneutic and legal philosophy have taught us that meaning cannot be constructed solely from the text; rather, "meaning depends on both culture and context." 202 That is, there is an inextricable bond between intrinsic and extrinsic context. ${ }^{203}$ The philosopher John Searle has referred to this extrinsic context as the "Background." 204 According to Searle:

The simplest argument for the thesis of the Background is that the literal meaning of any sentence can only determine its truth conditions or other conditions of satisfaction against a Background of capacities, dispositions, know-how, etc., which are not themselves part of the semantic content of the sentence. ${ }^{205}$

202. SUnSteIN, supra note 168 , at 114 ; see also G. B. MADISON, Understanding: A Phenomenological-Pragmatic ANALysis 137 (1982) ("Meaning is not natural but cultural, and like all other things cultural, such as social institutions, it is not, unlike behavior, something that can be seen and thus described; it can only be inferred from behavior."); REED DiCKERSON, THE INTERPRETATION AND APplication OF Statutes 103 n.2 (1975) (“. . . [P] eople can only communicate among themselves because they share a common culture. . . . Communication never takes place in a social vacuum, but always between individuals who are part of a total social context.") (quoting E. NidA, MESSAGE AND Mission 35, 94 (1960)).

203. See Taylor, supra note 168 , at 362-66. Theodore Schatzki notes this interrelationship between intrinsic and extrinsic context when discussing Wittgenstein's use of term "language game":

A language-game consists both of the use of a particular element of language (word, expression, sentence, etc.) and of features of the activities in which instances of that use are embedded .... [T] he use of language is one element among many in our activities, which themselves are embedded in a matrix of interrelated actual and possible activities, the totality of which constitutes the form of life in which the user of language finds himself.

Theodore R. Schatzki, The Prescription is Description: Wittgenstein's View of the Human Sciences, in The NeEd FOR Interpretation: Contemporary CONCEPTIONS OF THE PHILOSOPHER's TASK 118, 126 (S. Mitchell \& M. Rosen eds., 1983).

204. John R. SEarle, The Construction of Social Reality 130 (1995).

205. Id. See also John R. Searle, The Background of Meaning, in SPEECH ACT THEORY AND PRAgMATICS 221 (J. Searle et al. eds. 1980) ("[T]he meaning of a sentence only has application (it only, for example, determines a set of truth conditions) against a background of assumptions and practices that are not representable as a part of the meaning."); John R. SEARLE, EXPRession AND MEaning 117-36 (1979) (arguing that meaning is dependent on context); STANLEy Fish, Is THERE A TeXt IN This Class? The Authority of Interpretive Communities (1980) 
Indeed, several other notable thinkers such as Karl Llewellyn, ${ }^{206}$ Richard Posner, ${ }^{207}$ Pierre Bourdieu, ${ }^{208}$ Cass Sunstein,${ }^{209}$ and Stanley Fish $^{210}$ have expressed the importance of culture and extrinsic context in discerning meaning. Perhaps the most influential figure to do so was Ludwig Wittgenstein in his Philosophical Investigations. ${ }^{211}$ Wittgenstein's post-Tractarian philosophy (after 1929) eschewed the demand for Platonic certainty and a unified theory of language and posited that language is best understood as a labyrinth of interconnected practices. ${ }^{212}$ That is, the diversity and plurality of language make it

(asserting that what people call a literal meaning is merely the assumed, generally understood, implicit context).

206. See, e.g., Karl N. Llewellyn, The Common Law Tradition: Deciding APPEALS 268-85 (1960) (discussing what he referred to as "situation sense"); Wiseman, supra note 107 , at 505 (stating that Llewellyn sought "to codify the common practices and understandings of the marketplace. The rule relating to trade usage is one example: it simply provided that the usage of trade, or of a particular trade, is 'presumed to be the background which the parties have presupposed in their bargaining and have intended to read into the particular contract"); Patterson, supra note 107, at 206 ("Llewellyn was concerned with the relationship between words and the activities of which they are a part.").

207. See, e.g., POSNER, supra note 1, at 174 ("To read a case, to read a statute, a rule, or a constitutional clause presupposes a vast linguistic, cultural, and conceptual apparatus."); RICHARD A. POSNER, LAW AND LITERATURE 220 (1988) ("Words have reliable meaning only by virtue of their location in a sentence or larger verbal structure and often in a social practice as well."); Richard A. Posner, Legal Formalism, Legal Realism, and the Interpretation of Statutes and the Constitution, 37 CASE W. RES. L. REV. 179, 191 (1987) ("A text is clear only by virtue of linguistic and cultural competence.").

208. See, e.g., PIERre Bourdieu, Outline OF A TheOry OF Practice 72-95 (Richard Nice trans., 1977) (discussing the "habitus"). Searle notes that, "if I understand him correctly, Pierre Bourdieu's important work on the 'habitus' is about the same sort of phenomena that I call the Background." SEARLE, supra note 204, at 132.

209. See, e.g., SUNSTEIN, supra note 168, at 114 ("[W]ords are not self-defining. . . . They derive meaning from context and their background in the relevant culture."); Cass R. Sunstein, Principles, Not Fictions, 57 U. CHI. L. ReV. 1247, 1247 (1990) ("The meaning of any 'text' is a function not of the bare words, but of its context and the relevant culture.").

210. See, e.g., Stanley Fish, Doing What Comes Naturally (1989).

211. Wittgenstein, supra note 42; see also Phillip Bobbitt, Reflections Inspired By My Critics, 72 TEX. L. REV. 1869, 1948-49 (1994) (asserting that "drawing attention" to the relationship between social context and meaning "is the achievement for which [Wittgenstein] is best known to the public"). For a general discussion of Wittgenstein's later philosophy and the law, see WITTGENSTEIN AND LEGAL THEORY (Dennis M. Patterson ed., 1992).

212. See generally ROBERT J. ACKERMAn, WitTGENSTEIN's City, at 47-66 (1988); see also Linda Ross Meyer, When Reasonable Minds Differ, 71 N.Y.U. L. REV. 1467, 1477 (1996) ("Wittgenstein's principal insight is that the meaning of words is 
impossible to discern a universal linguistic algorithm. ${ }^{213}$ For Wittgenstein, the "philosophical concept of meaning has its place in a primitive idea of the way language functions." 14 This notion is nicely illustrated by Wittgenstein's "five red apples" example found in his Philosophical Investigations:

I send someone shopping. I give him a slip marked "five red apples". He takes the slip to the shopkeeper, who opens the drawer marked "apples"; then he looks up the word "red" in a table and finds a colour sample opposite it; then he says the series of cardinal numbers - I assume that he knows them by heart - up to the word "five" and for each number he takes an apple of the same colour as the sample out of the drawer. - It is in this and similar ways that one operates with words. - "But how does he know where and how is he to look up the word 'red' and what he is to do with the word 'five'?" - Well, I assume that he acts as I have described. Explanations come to an end somewhere. - But what is the meaning of the word "five"? - No such thing was in question here, only how the word "five" is used. ${ }^{215}$

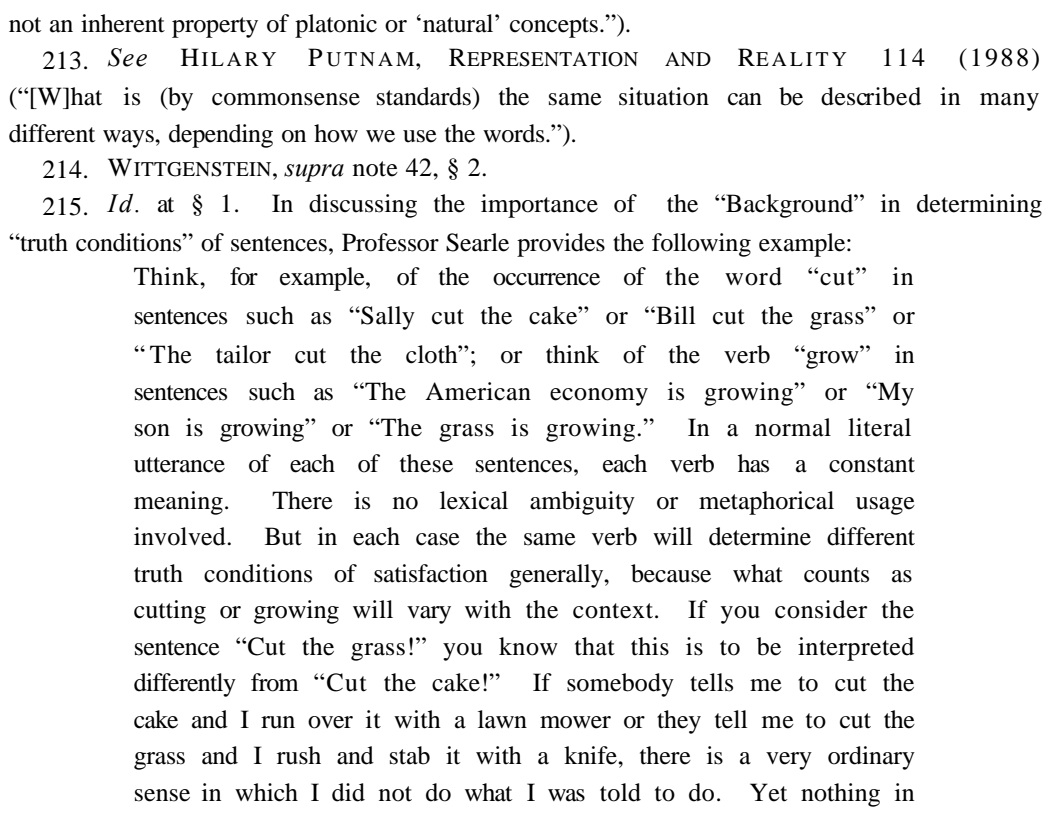


This example conveys Wittgenstein's belief that "the teaching of language is not explanation, but training." ${ }^{216}$ As Professors Baker and Hacker state, "[t]he meaning of a word is given by specification of its use," 217 that is, by observing the activities in which the shopkeeper is engaged. $^{218}$ In essence, Wittgenstein views these activities as the grammar of ideas, a grammar possessing certain conventions. He refers to this dynamic as a "language-game," 119 whereby "the speaking of language is part of an activity, or of a form of life. ${ }^{, 220}$ To understand

the literal meaning of those sentences blocks those wrong interpretations. In each case we understand the verb differently, even though its literal meaning is constant, because in each case our interpretation depends on our Background abilities.

SEARle, supra note 204, at 130-31. See also DenNis M. PATTERSON, LAW AND TRUTH 87 (1996) ("The criterion for understanding an utterance is not engagement of a process; rather, it is acting appropriately in response to the utterance. For example, one evinces understanding of the request 'Please pass the salt' by passing the salt or by explaining why it is impossible to do so.").

216. Wittgenstein, supra note 42, § 5; see also G.P. BAKER \& P.M.S. HACKER, WiTTGENSTEIN: UNDERSTANDING AND MEANING 71 (1980) ("Language must speak for itself. Consequently, grammatical explanations presuppose a background of prior understanding, a partial linguistic competence. With language-learners, such as we, explanation has a pedagogical role only after brute training has laid the foundation of elementary linguistic skills.").

217. BAKER \& HACKER, supra note 216, at 63; see also Dennis M. Patterson, Wittgenstein and the Code: A Theory of Good Faith Performance and Enforcement Under Article Nine, 137 U. PA. L. REV. 335, 355 ("The centerpiece of Wittgenstein's later philosophy is the doctrine of "meaning as use."').

218. Professors Baker and Hacker offer the following explanation of the "five red apples" example:

Each of the three words in 'five red apples' has a different use, and this can be described without answering questions such as 'What is the meaning of the word "five"?' — where 'meaning' is thought to be given by specification of an entity. Of course, [Wittgenstein's] point is that there is nothing left to say about the meaning of 'five' (properly understood) after its use has been described.

BAKER \& HACKER, supra note 216, at 63.

219. WitTGENSTEIN, supra note $42, \S 7$. Wittgenstein states, "I shall also call the whole, consisting of language and the actions into which it is woven, the 'languagegame." Id. By using the term "language-game," Wittgenstein is suggesting that meaning is discerned from examining the interrelationship between language and its contextual setting. See Schatzki, supra note 203, at 126 ; see also H.L. FINCH, WITTGENSTEIN 44-45 (1995).

220. Wittgenstein, supra note 42, $\$ 23$; see also $\mathrm{S}$. Hilmy, The LAter WITTGENSTEIN 163 (1987) ("One of the senses of the German word Leben is in the fact 'activity', and quite obviously the 'life' of which Wittgenstein is speaking here is the linguistic activity or locus of linguistic practice ...."). 
an idea, one must examine the activities that are part of the idea. ${ }^{221}$ Observing the application of words in action (i.e., activities), and not their origin, leads to understanding. ${ }^{222}$ As Professor Dennis Patterson explains, for Wittgenstein, "[a]ll understanding begins in language, but to understand the grammar of a concept one needs to investigate the point(s) the concept serves in social practices (the activities into which it is woven), which practices must themselves be the focus of attention in any investigation of meaning. ${ }^{2} 223$

Wittgenstein's approach to language informs us as to how words in a legal text are meaningful. By working within the text itself and participating in the activities associated therewith, one does not interpret the words in the text by focusing on the subjective intent of the author or by gazing through a mediating lens. Rather, meaning is discerned by examining the social practices in which these words are used. ${ }^{224}$

The insights of Wittgenstein and Searle are applicable to pragmatic textualism. Contrary to the assertion of some scholars, ${ }^{225}$ textualism,

221. Baker and Hacker state that two of the most important features of Wittgenstein's language-games are "context" and "activity of the game." With respect to the former, they write:

Like any other game, a language-game is 'played' in a setting. Wittgenstein's stress on the context of the game appears to be motivated by the wish to bring to the fore elements of linguistic activities which, while not obviously involved in the explanation of the meaning of constituent expressions[,] . . . are nevertheless pertinent to their meaning. At its most general the notion of context encompasses the presuppositions of meaning. If the context were significantly different, the game would not be played, for it would be pointless.

BAKER \& HACKER, supra note 216, at 96.

222. For Wittgenstein, study of the language-games "disperses the fog" so that one can "study the phenomena of language in primitive kinds of application in which one can command a clear view of the aim and functioning of the words." WTTGENSTEIN, supra note $42, \S 5$.

223. Patterson, supra note 217, at 363; see also FINCH, supra note 219, at 44 ("Grammatical remarks . . . are binding norms of language .... In them ... we see the meanings of a culture.").

224. See Wittgenstein, supra note 42, $\S 241-42$; see also PosNER, supra note 196, at 297 ("Much communication is tacit — a matter of shared practices — so you must understand an entire culture in order to be able to understand its writings."); Brian A. Langille, Revolution Without Foundation: The Grammar of Scepticism and Law, 33 MCGILL L.J. 451, 488 (1988) (asserting that the "central message" of Philosophical Investigations "is the idea of language as an activity (not a mental process)").

225. See, e.g., EsKRIDGE, supra note 1, at 34 (asserting that for textualists, "the beginning, and usually the end, of statutory interpretation should be the apparent meaning of the statutory language"); Bell, supra note 2, at 60 (critics of textualism 
particularly what I refer to as pragmatic textualism, is not wedded solely to the text. ${ }^{226}$ Indeed, many textualists understand that "the meaning of a word is its use in the language" 227 - a public language

contend that since words have no inherent meaning outside their context, "heavy reliance on text to interpret statutes will produce unreasonable, stilted, and erroneous interpretations of statutes. Words have meaning only within the context in which they are used, and thus context must be considered in interpreting statutory text.").

226. See Manning, supra note 2, at 696 ("Not even the most committed textualist would claim that statutory texts are inherently 'plain on their face,' or that all interpretation takes place within the four corners of the Statutes at Large."); Daniel A. Farber, The Inevitability of Practical Reason: Statutes, Formalism, and the Rule of Law, 45 VAND. L. REV. 533, 546 (1992) ("To deride [textualism] as mindless literalism would clearly be a mistake. On the contrary, Justice Scalia's approach extends beyond the dictionary meaning of the phrase in dispute to include a fairly rich array of other factors.").

227. WitTGENSTEIN, supra note 42, § 43; see also Easterbrook, supra note 13, at 64 ("Because interpretation is a social enterprise, because words have no natural meanings, and because their effect lies in context, we must consult these contexts."); Philip P. Frickey, Faithful Interpretation, 73 WASH. U. L. REV. 1085, 1093 (1995) ("[A]lthough the new textualism is sometimes condemned for reliance upon ridiculous assumptions about texts having acontextual meaning, the more sophisticated practitioners of that craft are innocent of any such crime."); Karkkainen, supra note 41, at 412 ("For Justice Scalia, statutory interpretation is not purely textually-driven. Instead, interpretation may require an evaluation of the statute's policy and purpose, which are determined in large measure by the factual circumstances and institutional arrangements that form the background against which the statute was enacted."); Merrill, supra note 91, at 351-52 ("Textualism is not simply a revival of the old plain meaning rule. It is a sophisticated theory of interpretation which readily acknowledges that the meaning of words depends on the context in which they are used."); Antonin Scalia, Is There an Unwritten Constitution?, 12 HARV. J.L. \& PUB. POL'Y 1, 1 (1989) (asserting that an "unwritten Constitution . . . encompasses a whole history of meaning ...."). 
replete with underlying assumptions. ${ }^{228}$ As noted by Judge Frank Easterbrook,

Wittgenstein showed that no system of language can be self-contained and that meaning thus must depend in part on logical structure and understandings supplied by a community of readers, but this does not establish that words contain no meaning or that judges may disregard such meaning as most readers would find. There is no "private language"; meaning lies in shared reactions to text. If readers have a common understanding of structure they may decipher meaning accurately. ${ }^{229}$

This language indicates that Judge Easterbrook subscribes to the "community consensus" view ${ }^{230}$ of Wittgenstein that has its

228. Professors Baker \& Hacker explain this "contextualism" as follows:

A sentence is akin to a move in chess, and a move is only a move in the context of a game. So even a sentence has no meaning in isolation. Understanding a language is the background against which a sentence acquires meaning, as understanding chess is for a move. A sentence is a position in the "game of language," hence to understand a sentence is to understand a language. Thus interpreted, the contextual dictum is directly connected with use. It is connected with structure only in so far as structure reflects use.

BAKER \& HACKER, supra note 216, at 280; see also MiCHAEL J. OAKESHOTT, Political Education, in RAtionalism IN POLITICS AND OTHER ESSAYs 111, 129 (1962) ("We do not begin to learn our native language by learning the alphabet, or by learning its grammar; we do not begin by learning words, but words in use."); C.K. Ogden \& I.A. Richards, The MEAning OF MEANing 9-10 (1923) ("Words, as every one now knows, 'mean' nothing by themselves . . . It is only when a thinker makes use of them that they stand for anything, or, in one sense, have 'meaning."'); Thomas Morawetz, WitTGenstein AND KNowledge 5-33 (1978) (discussing Wittgenstein's notion of practice).

229. Frank H. Easterbrook, Statutes' Domain, 50 U. CHI. L. REv. 533, 533 n.2 (1983); see also In re Sinclair, 870 F.2d 1340, 1342 (7th Cir. 1989) ("An unadorned 'plain meaning' approach to interpretation supposes that words have meanings divorced from their contexts-linguistic, structural, functional, social, historical. Language is a process of communication that works only when authors and readers share a set of rules and meanings."); Continental Can Co., v. Chicago Truck Drivers Pension Fund, 916 F.2d 1154, 1157 (7th Cir. 1990) ("You don't have to be Ludwig Wittgenstein or HansGeorg Gadamer to know that successful communication depends on meanings shared by interpretive communities.").

230. See Norman Malcolm, Nothing is Hidden 156 (1986). 
underpinning in section 202 of the Investigations: “[O]beying a rule' is a practice. And to think one is obeying a rule is not to obey a rule. Hence it is not possible to obey a rule 'privately': otherwise thinking one was obeying a rule would be the same thing as obeying it." 231 Thus, given Judge Easterbrook's remark that "meaning lies in shared reactions to text," 3232 he would likely concur with Norman Malcolm that "for Wittgenstein the concept of a rule presupposes a community within which a common agreement in actions fixes the meaning of a rule."233

\section{B. Pragmatic Textualism and the Useful Arts}

1. The Centrality of the Artisan

Upon reading Federal Circuit opinions written by both hypertextualists and pragmatic textualists, one reads time and again that "the focus in construing disputed terms in claim language is ... on the objective test of what one of ordinary skill in the art at the time of the invention would have understood the term to mean." ${ }^{234}$ Despite this language, the hypertextualist judge takes an expansive view of judicial power and positions himself as both judge and artisan. Yet, without the assistance of a skilled artisan, how can the hypertextualist live up to the

When Wittgenstein says that following a rule is a practice, I think he means that a person's actions cannot be in accord with a rule unless they are in conformity with a common way of acting that is displayed in the behaviour of nearly everyone who has had the same training. This means that the concept of following a rule implies the concept of a community of rulefollowers."

Id.; see also Dennis M. Patterson, Law's Pragmatism: Law as Practice and Narrative 76 VA. L. REV. 937, 939 (1990).

231. WitTGENSTEIN, supra note $42, \S 202$.

232. Easterbrook, supra note 229, at 533 n.2.

233. Malcolm, supra note 230, at 175; see also Christopher Peacocke, Reply: Rule Following: The Nature of Wittgenstein's Arguments, in WITTGENSTEIN, To Follow A Rule 73 (Steven H. Holtzman \& Christopher M. Leich eds. 1981) ("[W]hat is it for a person to be following a rule, even individually, cannot ultimately be explained without reference to some community."); SAUL A. KRIPKE, WitTGENSTEIN ON RULES AND PRIVATE LANGUAGE 7-10 (1982).

234. See, e.g., Markman v. Westview Instruments, Inc., 52 F.3d 967, 986 (Fed. Cir. 1995); Multiform Desiccants, Inc. v. Medzam, Ltd., 133 F.3d 1473, 1477 (Fed. Cir. 1998) ("It is the person of ordinary skill in the field of the invention through whose eyes the claims are construed.”); Hoechst Celanese Corp. v. BP Chemicals Ltd., 78 F.3d 1575, 1578 (Fed. Cir. 1996) ("A technical term used in a patent document is interpreted as having the meaning that it would be given by persons experienced in the field of the invention ...."). 
promise of Markman I to "arrive at the true and consistent scope of the patent owner's rights?"235

What is meant by the words "true" and "objective"? Is the hypertextualist judge endorsing a correspondence theory of truth $?^{236}$ This would be particularly bold (especially for an appellate judge) because, as Richard Rorty has asserted, it is "impossible . . . to step outside our skins - the traditions, linguistic and other, within which we do our thinking and self-criticism - and compare ourselves with something absolute." 237 The more plausible meaning of the words "true" and "objective" is, as a pragmatic textualist would assert, that which is "capable of commanding agreement among all members of a group subscribing to common principles." 238 As such, only patent law's PHOSITA is positioned to provide the technical knowledge that is needed to arrive at a meaning consistent with how the disputed claim language is understood in the germane technological community. This is why the characterization of claim construction as a question of law subject to de novo review is a fiction.

A hypertextualist's approach does not look to see how the claim language is used in practice; rather, it may choose a meaning proffered by one of the parties or a construction in accord with the judge's

\footnotetext{
235. Markman, 52 F.3d at 979.

236. The correspondence theory of truth holds that a statement is true if the statement corresponds with the way the world is; that is, the statement corresponds to an objective reality. See THE OXFORD COMPANiOn TO PHILOSOPHY 166-67 (1995); see also MORTIMER J. ADLER, SIX GREAT IDEAS 42 (1981) ("[T]he truth of thought consists in the agreement or correspondence between what one thinks, believes, or opines and what actually exists or does not exist in the reality that is independent of our minds and of our thinking one thing or another."); Kenneth J. Kress, Why No Judge Should Be a Dworkian Coherentist, 77 TEX. L. REV. 1375, 1380 (1999) ("Correspondence theories of truth evoke the image of true propositions mirroring reality.").

237. RORTY, supra note 1, at xix; see also POSNER, supra note 1, 205, at 18 (asserting that nobody "knows the way things really are"); HILARY PUTNAM, REASON, TRUTH, AND HISTORY 50 (1981) (arguing that under an "internalist perspective," truth is "not correspondence with mind-independent or discourse-independent 'states of affairs.' There is no God's Eye point of view that we can know or usefully imagine").

238. Posner, supra note 1 , at 18 ; see also PUTNAM, supra note 213 , at 115 ("[W]e can explain what "correct to use the words of which the statement consists in that way' means by saying that it means nothing more nor less than a sufficiently well placed speaker who used the words in that way would by fully warranted in counting the statement as true of that situation."); William JAMES, Pragmatism, in Pragmatism And Four EsSAys From The MEAning OF Truth 59 (1955) ("The true is the name of whatever proves itself to be good in the way of belief . . .").
} 
background assumptions. ${ }^{239}$ In contrast, the pragmatic textualist judge understands that there are normative components or rules in the institutional structure of each technological field, and judges are simply too far removed from this structure to develop a set of background assumptions essential to discerning the "true" and "objective" meaning of claim language. ${ }^{240}$ As Judge Easterbrook wrote, "What seems clear to a judge may read otherwise to a skilled designer." ${ }^{241}$ This understanding sanctions the notion that "context encompasses the presuppositions of meaning," ${ }^{242}$ and recognizes that the artisan "has developed a set of capacities and abilities that render him at home in [his technological] society. ${ }^{2} 43$

239. See, e.g., Exxon Chem. Patents, Inc. v. Lubrizol Corp., 64 F.3d 1553 (Fed. Cir. 1995); see also Douglas Y'Barbo, Is Extrinsic Evidence Ever Necessary to Resolve Claim Construction Disputes?, 81 J. PAT. \& TRAdEMARK OFF. SOC'Y, 567, 573 (1999) ("The Markman Court resolved the dispute not by asking what the term actually meant - but instead by checking each of the two proffered conjectures against the text and eliminating the one that fails to preserve the text's internal coherence.").

As a matter of doctrine, this approach disregards the fact that the "inventor, for purposes of legal reasoning, has been replaced ... by the statutory hypothetical 'person having ordinary skill in the art' . . ." Kimberly-Clark Corp. v. Johnson \& Johnson, Inc., 745 F.2d 1437, 1454 (Fed. Cir. 1984) (footnote omitted); see also Standard Oil Co. v. American Cyanamid Co., 774 F.2d 448, 454 (Fed. Cir. 1985), wherein the court stated:

The statutory emphasis is on a person of ordinary skill. Inventors, as a class, according to the concepts underlying the Constitution and the statutes that have created the patent system, possess something - call it what you will - which sets them apart from the workers of ordinary skill, and one should not go about determining obviousness under $\S 103$ by inquiring into what patentees (i.e., inventors) would have known or would likely have done, faced with the revelation of references.

240. See SeARLE, supra note 204 , at $145-47$; see also BAKER \& HACKer, supra note 216, at 93 ("The foundation of the ability to play a game lies in training; the ability to play it is mastery of a technique. Playing games is a human activity, and its existence presupposes common reactions, propensities, and abilities.").

241. In re Mahurkar Double Lumen, 831 F. Supp. 1354, 1359 (N.D. Ill. 1993)

(Easterbrook, J., sitting by designation).

242. BAKER \& HACKER, supra note 216, at 96.

243. SEARLE, supra note 204, at 147. According to Posner:

[A]lmost everyone . . . would . . . admit that the experimental, statistical, predictive, and observational procedures of modern science, together with the technical capability of embodying and thereby testing scientific theories in technology . . . enable many scientific ideas to be reasonably held with a degree of confidence . . . that enables them to be called 'true' without a sense of strain, rather than merely convenient to believe. 
Indeed, just as a legislator "must operate within the prevailing interpretive culture," ${ }^{244}$ the skilled artisan has knowledge of the underlying background assumptions and linguistic customs within his technological community. ${ }^{245}$ When the hypertextualists assert that competitors of the patentee should "rest assured . . that a judge, trained in the law, will similarly analyze the text of the patent and its associated public record and apply the established rules of construction" to arrive at the true scope of the patent grant, they ignore the cultural divide between judge and artisan. ${ }^{246}$ Given the exclusion of extrinsic evidence, the phrase "similarly analyze the text" seems to suggest that the hypertextualist judge is asking the artisan to engage in an interpretive paradigm shift and think (counterintuitively) like a judge and "apply established rules of construction," rather than, as the patent code requires, the judge think like an artisan and familiarize himself with the artisan's communal norms. ${ }^{247}$ Thus, hypertextualism greatly increases what we might refer to as the artisan's interpretation costs. ${ }^{248}$

The late Judge Nies, in discussing the distinction between the phrases "in the prior art" and "from the prior art" when determining obviousness under 35 U.S.C. $§ 103$, noted the relevance of the artisan's background assumptions:

POSNER, supra note 1 , at 36.

244. SunSTEIN, supra note 168 , at 114 .

245. See Multiform Desiccants, Inc. v. Medzam, Ltd., 133 F.3d 1473, 1477 (Fed. Cir. 1998) (patent law's artisan "is deemed to read the words used in the patent documents with an understanding of their meaning in the field, and to have knowledge of any special meaning and usage in the field."); In re Nilssen, 851 F.2d 1401, 1403 (Fed. Cir. 1988) ("The board attributes to the 'hypothetical person' knowledge of all prior art in the field of the inventor's endeavor and prior art solutions for a common problem even if outside that field. That view accords with the plethora of this court's precedent."); Cable Elec. Prods., Inc. v. Genmark, Inc., 770 F.2d 1015, 1025 (Fed. Cir. 1985) ("In evaluating obviousness, the hypothetical person of ordinary skill in the pertinent art is presumed to have the 'ability to select and utilize knowledge from other arts reasonably pertinent to [the] particular problem' to which the invention is directed.") (quoting In re Antle, 444 F.2d 1168, 1171-72 (C.C.P.A. 1971)).

246. In a concurring opinion shortly after Markman $I$ was decided, Judge Mayer, after noting the "artificiality" of Markman I, stated, "How [Markman I] fosters greater predictability and consistency in the law or a certainty that a judge will "arrive at the true and consistent scope of the patent owner's rights" is beyond my understanding." Pall Corp. v. Micron Separations, Inc., 66 F.3d 1211, 1224 (Fed. Cir. 1995) (Mayer, J., concurring).

247. See Cybor. v. FAS Techs., Inc., 138 F.3d 1448, 1475 (Fed. Cir. 1998) (Rader, J., dissenting) (asserting that by embracing de novo review and excluding extrinsic evidence, the majority "has sub silentio redefined the claim construction inquiry as "how a lawyer or judge would interpret the term"').

248. I am grateful to Thomas Cotter for this point. 
The word "from" expresses the idea of the statute that we must look at the obviousness issue through the eyes of one of ordinary skill in the art and what one would be presumed to know with that background. What would be obvious to one of skill in the art is a different question from what would be obvious to a layman. An artisan is likely to extract more than a layman from reading a reference.

... [A] suggestion or motivation to combine prior art teachings can derive solely from the existence of a teaching, which one of ordinary skill in the art would be presumed to know, and the use of that teaching to solve the same or similar problem which it addresses. $^{249}$

Although $\S 112$, I 2 requires the patent applicant to claim his invention with particularity, the meaning of claim language is derived from extrinsic contextual sources - namely, the technological community and the customs to which the invention pertains. ${ }^{250}$ Thus, the extrinsic evidence is as much a part of the public record as is intrinsic evidence. This inextricable link between intrinsic and extrinsic context is reflected in several provisions of the patent code that place the PHOSITA at center stage. For example, two of arguably the most important sections of the patent code require that to be patentable, the claimed invention must not be "obvious" to a "person having ordinary skill in the art," 251 and must "enable" a "person skilled in the art" to make and use the claimed invention. ${ }^{252}$

249. In re Oetiker, 977 F.2d 1443, 1448 (Fed. Cir. 1992).

250. The Supreme Court expressed this sentiment nearly 140 years ago in Bischoff v. Wethered, 76 U.S. 812 (1869):

[T] he whole subject-matter of a patent is an embodied concept outside of the patent itself . . . This outward embodiment of the terms contained in the patent is the thing invented, and is to be properly sought, like the explanation of all latent ambiguities arising from the description of external things, by evidence in pais.

Id. at 815; see also Toro v. White Consol., 199 F.3d 1295, 1299 (Newman, J.) ("Determining the limits of a patent claim requires understanding its terms in the context in which they were used by the inventor, considered by the examiner, and understood in the field of the invention."); CORBIN, supra note 86, § 555 ("[U]sages and customs are a part of those circumstances by which the meaning of words is to be judged.").

251. 35 U.S.C. $\$ 103($ a) (1994).

252. 35 U.S.C. § 112 (1994); see also, Elf Atochem N. Am., Inc. v. Libbey-Owens- 
The hypertextualist philosophy relies too heavily on the power of the word to convey meaning with clarity. In patent law, as in any area of the law, the communicative force of the written word has its limits, and these inherent limitations do not discriminate between technical and non-technical terms. Take the example of the oft-used claim words "substantially equal to," "closely approximate," or "close to." These non-technicalterms are ambiguous when viewed acontextually. Yet the Federal Circuit has recognized their importance in claim drafting, ${ }^{253}$ stating that their "acceptability depends on "whether one of ordinary skill in the art would understand what is claimed." ${ }^{254}$ In short, only by turning to technological custom and culture can we understand claim meaning.

Therefore, the phrase "claim interpretation" is a misnomer. ${ }^{255}$ Understanding the meaning of claim language usually does not entail interpretation; ${ }^{256}$ rather, understanding the meaning of claim language is

Ford Co., 894 F.Supp. 844, 858 ("The patent laws focus the requirements of the information that must appear in each patent and its claims on those skilled in the art."). The Federal Circuit, as part of its common law, has developed various tests that are satisfied (or not) from the perspective of the artisan. See, e.g., Vas-Cath, Inc. v. Mahurkar, 935 F.2d 1555, 1563 (Fed. Cir. 1991) (stating that to satisfy the "written description" requirement, the applicant must "reasonably convey[] to the artisan that the inventor had possession" of the claimed invention as required by 35 U.S.C. $\S 112$ ).

253. See Rosemount, Inc. v. Beckman Instruments, Inc., 727 F.2d 1540, 1546-47 (Fed. Cir. 1984); Andrew Corp. v. Gabriel Elecs., Inc., 847 F.2d 819, 821 (Fed. Cir. 1988) (Newman, J.).

254. Andrew, 847 F.2d at 821 (quoting Seattle Box Co. v. Indus. Crating \& Packaging, 731 F.2d 819, 826 (Fed. Cir. 1984).

255. I use the word "interpretation" here to mean making a choice between two or more communally accepted meanings of the claim language in question. See PATTERSON, supra note 215, at 86 ("Interpretation in law involves a decision about how, from among several candidates, one chooses whether to extend a rule one way rather than another. Interpretation becomes necessary only when some real doubt exists about how to apply a rule."); POSNER, supra note 196, at 460 ("The essence of interpretive decision making is considering the consequences of alternative decisions.").

256. See Wittgenstein, supra note 42, $\$ 201$ ("[T]here is a way of grasping a rule which is not an interpretation, but which is exhibited in what we call 'obeying the rule' and 'going against it' in actual cases .... [T]here is an inclination to say: every action according to the rule is an interpretation. But we ought to restrict the term 'interpretation' to substitution of one expression of the rule for another."); PATTERSON, supra note 215, at 71-98. According to Searle:

I am reluctant to use the word 'interpretation' because it suggests something that is definitely false. The use of this word suggests that there is an act of interpreting whenever we understand something or perceive something, and of course I don't want to say that. I want to say we normally just see an object or understand a sentence, without any act of interpreting. 
a result of understanding how the language is used in practice. ${ }^{257}$ In fact, Judge Newman has noted the importance of ascertaining "the specific meaning of a technical term as it is used and understood in a particular technical field." ${ }^{258}$ The artisan can be viewed as part of a technological community within which there is common agreement on the meaning of the disputed claim language. ${ }^{259}$ Indeed, agreement is more likely in a scientific community (as opposed to, say, a literary community) where statistical and experimental procedures "enable many scientific ideas to be reasonably held with a degree of confidence ... that enables them to be called 'true' without a sense of strain, rather than merely convenient to believe." ${ }^{.260}$ Indeed, the patent code requires

SEARLE, supra note 204, at 134.

257. See Wittgenstein, supra note 42, $\S 202$ ("'Obeying a rule' is a practice. And to think one is obeying a rule is not to obey a rule."). According to Patterson: If all understanding were interpretation, then each interpretation would itself stand in need of interpretation, and so on, infinitely regressing to infinity. This logical problem, one long ago recognized, suggests that there is something deeply wrong with assigning to interpretation a mediating role between utterances and the understanding of them. The only way out of this vicious regress is to recognize that the normativity of rule-guided behavior (e.g., law) lies not in the act of the individual (e.g., interpretation) but in a practice.

PATTERSON, supra note 215 , at 88.

258. Hoechst Celanese Corp. v. BP Chems., Ltd., 78 F.3d 1575, 1580 (Fed. Cir. 1996) (Newman, J.).

259. See ThOMAS, supra note 4, at 185 n.6 (asserting that "we can at least acknowledge that the patent professionals form an interpretive community"); PUTNAM, supra note 237, at 52 (asserting that "signs do not intrinsically correspond to objects, independently of how those signs are employed and by whom. But a sign that is actually employed in a particular way by a particular community of users can correspond to particular objects within the conceptual scheme of those users."); see also WitTGENstein, supra note 42, § 198 ("Interpretations by themselves do not determine meaning ... [A] person goes by a sign-post only in so far as there exists a regular use of sign-posts, a custom."); MALCOLM, supra note 230, at 173 ("Wittgenstein stresses the point that a language can exist only if there is agreement between persons in their applications of the language.").

260. Posner, supra note 1, 205, at 36; see also JOHN DEWEY, THE QUEST FOR CERTAinty 310-11 (1960). As the well-known physicist Steven Weinberg has noted, "[m]eanings do change, but generally they do so in the direction of an increased richness and precision of definition, so that we do not lose the ability to understand the theories of past periods of normal science." Steven Weinberg, The Revolution That Didn't Happen, in THE New York Review of Books 48, 49 (October 8, 1998). Thus, for Weinberg, scientific progress represents a "cumulative approach to truth." $I d$. at 50. The "neo-pragmatists," such as Rorty, have expressed a more skeptical attitude toward science - certainly more so than Dewey — and have asserted that there is nothing 
that the operability of the claimed invention be testable and directly observable. ${ }^{261}$

Patent law, perhaps more than any other area of the law, provides the judge with access to the scientific method and the "prediction" and "control" that accompany it. ${ }^{262}$ However, the hypertextualist judge ignores this direct pipeline to the technological community and chooses instead to engage in a de novo, acontextual interpretive analysis through

distinctive about the scientific method. See Richard Rorty, The Banality of Pragmatism and the Poetry of Justice, 63 S. CAL. L. REv. 1811, 1813 (1990) ("[W]e have all read Kuhn, Hanson, Toulmin, and Feyerabend, and have thereby become suspicious of the term 'scientific method."'). Indeed, Posner is quick to recognize that pragmatism has shifted "the emphasis in the philosophy of science from the discovery of nature's laws by observation to the formulation of theories about nature." POSNER, supra note 1, at 464. After the publication of Thomas Kuhn's groundbreaking The Structure of Scientific Revolutions, it became explicit "that scientific theories are a function of human need and desire rather than of the way things are in nature." Id. However, according to Posner, "[t]his need not make the pragmatist unfriendly to science." Id. As Brian Tamanaha writes:

This objection [i.e., that there is nothing distinctive about the scientific method] is devastating only if Dewey and James did see the scientific method as something distinct .... The essence of the method lies in an attitude which involves detached and impartial inquiry (which does not rule out having an opinion based on faith or insight to guide the inquiry), close attention to the facts, and experimentation and testing.... So the issue is not whether the method of inquiry proposed by Dewey and James is uniquely scientific, but whether it is useful and productive in the accumulation of knowledge. On that score there can be no doubt.

Brian Z. Tamanaha, Pragmatism in U.S. Legal Theory: Its Application to Normative Jurisprudence, Sociolegal Studies, and the Fact-Value Distinction, 41 AM. J. JURIS. 315, 352-53 (1996); see also Susan Haack, Pragmatism, in THE BLACKWELL COMPANION TO PHiLOSOPHY 643 (1996). According to Haack:

Rorty appeals to Dewey's repudiation of the epistemological tradition. But the appeal is strained, for Dewey looks to the 'naturalization of intelligence,' to a scientific approach to replace the 'spectator theory of knowledge,' while Rorty declares that epistemology needs no successor-subject, and, far from welcoming a shift towards science, anticipates the future of post-philosophy as a genre of literature or of literary criticism.

Id. at 654 .

261. See 35 U.S.C. $\$ \S 101,112$.

262. See, e.g., Stephen Breyer, Science in the Courtroom, ISUES IN SCIENCE AND TEChNOLOGY 52 (Summer 2000) ("The legal disputes before us increasingly involve the principles and tools of science. Proper resolution of those disputes matters not just to the litigants, but also to the general public - those who live in our technologically complex society and whom the law must serve."). 
a mediating lens. ${ }^{263}$ This approach, adopted in Markman I and affirmed in Cybor, ineluctably leads to an opportunity for judges to entertain their own background assumptions and biases, ${ }^{264}$ which are themselves a form of extrinsic evidence. Indeed, instead of an exercise in exegesis when construing a claim, the hypertextualist delivers eisegesis. As Arthur Corbin noted:

$[\mathrm{N}]$ o relevant credible evidence is inadmissible merely because it is extrinsic; all such evidence is extrinsic. When a court makes the often repeated statement that the written words are so plain and clear and unambiguous that they need no interpretation and that evidence is not admissible, it is making an interpretation on the sole basis of the extrinsic evidence of its own linguistic experiences and

263. Even if we were to accept an antifoundationalist view of science, the scientific method would still provide greater exactitude and reflect, at least as of the moment, the beliefs of those who matter most - the artisans who rely and build upon extant patented technology. The reason there is usually a commonly held view within a technical community is because of the scientific method. As Posner writes:

What is missing from law are penetrating and rigorous theories, counterintuitive hypotheses that are falsifiable but not falsified (and so are at least tentatively supported), precise instrumentation, an exact vocabulary, a clear separation of positive and normative inquiry, quantification of data, credible controlled experiments, rigorous statistical inference, useful technological byproducts, dramatic interventions with measurable consequences, and above all and subsuming most of the previous points, objectivity testable - and continually retested - hypotheses.

PosNer, supra note 196, at 69. In addressing Thomas Kuhn's incommensurability argument (that is, the argument that as scientific paradigms shift, the standards by which scientific theories are judged also changes), Weinberg states that while "[o]ur ideas have changed,. . . we have continued to assess our theories in pretty much the same way: a theory is taken as a success if it is based on simple general principles and does a good job of accounting for experimental data in a natural way." Weinberg, supra note 260, at 50. In the end, "[w]hat drives us onward in the work of science is precisely that there are truths out there to be discovered that once discovered will form a permanent part of human knowledge." Id.

264. See K-2 Corp. v. Salomon S.A., 191 F.3d 1356, 1370 (Fed. Cir. 1999) (Rader, J., dissenting) ("When judges intuit an ordinary and accustomed meaning divorced from context, they are (usually unwittingly) imposing their own subjective linguistic values on a public decision."); Cybor Corp. v. FAS Techs., Inc., 138 F.3d 1448, 1475 (Fed. Cir. 1998) (Rader, J., dissenting) (asserting that by embracing de novo review and excluding extrinsic context, the Cybor majority "has sub silentio redefined the claim construction inquiry as "how a lawyer or judge would interpret the term"'). 
education, of which it merely takes judicial notice. ${ }^{265}$

As of late, the pragmatic textualist's response to hypertextualism's disregard of the artisan and his community's underlying assumptions has been more pronounced and candid. For instance, in $K-2$ Corp. $v$. Salomon S.A., ${ }^{266}$ Judge Rader, in a dissenting opinion, criticized the majority for not considering technological or extrinsic context in its claim interpretation analysis. ${ }^{267}$ The patent related to in-line roller skates, and the disputed claim term was "permanently affixed." ${ }^{268}$ According to Judge Rader, the majority, while stating that "claim construction is firmly anchored in reality by the understanding of those of ordinary skill in the art," ${ }^{, 269}$ proceeded to interpret the claim without exploring the underlying assumptions or context of in-line skating technology:

[T] his court does not even consider the meaning an ordinary in-line skate artisan would attach to "permanently."...

Divorced from context, words lose their ordinary and accustomed meanings. "Permanent" in the context of mountain ranges can mean millennia; "permanent" in the context of hair treatments can mean until the next rain storm; "permanent" in the context of creased pants can mean until the next long airline trip in coach class; "permanent" in the context of genetic combinations can mean until the next mutation. When judges intuit an ordinary and accustomed meaning divorced from context, they are (usually unwittingly) imposing their own subjective linguistic values on a public decision.

As this court verbally recognizes but substantively ignores, the understanding of one of ordinary skill in the art sets the proper context for the meaning of claim terms. ${ }^{270}$

265. Corbin, supra note 196, at 189 (emphasis added).

266. 191 F.3d 1356 (Fed. Cir. 1999)

267. See id. at 1370-71.

268. Id. at 1360 .

269. Id. at 1365 .

270. Id. at 1370; see also Judge Rader's comments in Pitney Bowes, Inc. v. HewlettPackard Co., 182 F.3d 1298, 1314 (Fed. Cir. 1999) (Rader, J., additional views), wherein he stated:

Vitronics offers good counsel when it urges trial judges to focus on 
Thus, much like Corbin's and Llewellyn's emphasis on custom and trade usage in response to the Willistonian or classical contract model, the pragmatic textualists on the Federal Circuit understand that meaning is derived from asking how persons of ordinary skill in the art understand the claim language in question. The virtues of predictability and certainty are achieved (or, at least, realized to a greater extent than they would be under a hypertextualist approach) because technical terms, through custom, training, and the cumulative nature of complex technology, have acquired a common meaning that is shared by the artisans of the relevant technological community. ${ }^{271}$ Indeed, within a technological community where cumulativeness of invention and a shared understanding are prominent, there can be a great deal of crosslicensing and cooperation among inventive entities. ${ }^{272}$

This is not say that there will never be a need for interpretation whereby the judge will have to make a choice among competing constructions. There may be more than one underlying assumption present in a technological community, and how a judge, untrained in the relevant technology, addresses this disagreement among artisans is an issue of great importance - and one that is made more difficult as a result of the so-called "battle of the experts" or, what can be referred to as "partisan-artisans," who, armed with powerful Ph.Ds, are more

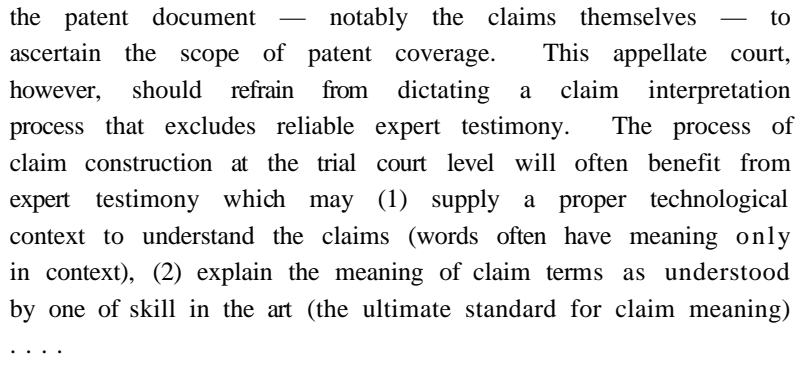

271. See POSNER, supra note 1, at 37 ("One can expect . . . that political, selfinterested, traditional, habitual, or other truth-independent considerations will play a far larger role in explaining the content, character, and acceptance of legal ideas than they play in the case of modern science, where the relevant community agrees on the criteria for verification."); see also WITTGENSTEIN, supra note 42, § 240, at 880 ("Disputes do not break out (among mathematicians, say) over the question whether a rule has been obeyed or not. People don't come to blows over it, for example. That is part of the framework on which the working of our language is based . . . ."); Felix Frankfurter, Some Reflections on the Reading of Statutes, 47 Colum. L. REV. 527, 528 (1947) (stating that words "are symbols of meaning. But unlike mathematical symbols, the phrasing of a document, especially a complicated enactment, seldom attains more than approximate precision.").

272. See, e.g., Merges, supra note 178; Scotchmer, supra note 171. 
than willing to share their views in court. There are initially two responses that, although not solving the problem of ambiguity, add resolution to the inquiry. First, a judge may appoint a disinterested expert pursuant to section 706 of the Federal Rules of Evidence, ${ }^{273} \mathrm{a}$ special master, ${ }^{274}$ or engage in other case-management techniques. ${ }^{275}$ Such an appointment is designed, of course, to ameliorate or avoid the problems associated with partisan bickering between the litigants' experts, to inject a certain degree of neutrality into the process, and to aid the judge in sifting through "truth-independent" assertions. Second, the patent $\operatorname{code}^{276}$ and the common law offer some resolution as to the interpretive audience. Recall that claims are written with the artisan of ordinary skill in mind, not a lay person or even the inventor. ${ }^{277}$ The Federal Circuit has endorsed several factors to be considered in determining level of ordinary skill. ${ }^{278}$

In the end, differences within a specific technological community will exist. These differences in understanding, however, do not mean that the text and only the text should be consulted for claim meaning. Rather, my response to this problem is for the Federal Circuit to exercise obeisance toward the district court and to be more sensitive to process considerations, including notions of institutional competence.

273. See FED. R. EVID. 706(a) ("The court may appoint any expert witness agreed upon by the parties, and may appoint expert witnesses of its own selection."); see, e.g., TM Patents v. Int'l Bus. Mach. Corp., 72 F. Supp. 2d 370, 374 (S.D.N.Y. 1999) (appointing a "disinterested expert and technical advisor"); Rohm \& Haas Co. v. Lonza, Inc., 997 F. Supp. 635, 638 (E.D. Pa. 1998) (appointing an independent expert); Genentech, Inc. v. Boehringer Mannheim GmbH, 989 F.Supp. 359, 365 (D. Mass. 1997) (appointing a neutral expert to testify how claim language is used by a person of ordinary skill in the art).

274. See FED. R. CIV. P. 53(a); see, e.g., Calabrese v. Square D Co., 14 F. Supp. 2d 1050, 1051 (N.D. Ill. 1998).

275. See Breyer, supra note 262, at 55 (relating that one judge in Alabama recently appointed a "neutral science panel" of scientists in the silcone gel breast implant litigation).

276. See, e.g., 35 U.S.C. $\$ \S 103,112$ (1994).

277. See Kimberly-Clark Corp. v. Johnson \& Johnson, 745 F.2d 1437, 1454 (N.D. Ill. 1984) (asserting that the "hypothetical person is not the inventor, but an imaginary being possessing 'ordinary skill in the art' created by Congress to provide a standard of patentability.").

278. See Env'l Designs, Ltd. v. Union Oil Co., 713 F.2d 693, 696 (Fed. Cir. 1983) ("(1) the education level of the inventor; (2) type of problems encountered in the art; (3) prior art solutions to those problems; (4) rapidity with which innovations are made; (5) sophistication of the technology; and (6) educational level of active workers in the field"); see also Custom Accessories, Inc. v. Jeffrey-Allan Indus., Inc., 807 F.2d 955, 962-63 (Fed. Cir. 1986) ("[N]ot all such factors may be present in every case, and one or more of them may predominate.”). 
I pose the following question: Who is better positioned to choose (i.e., to interpret) between or among competing background assumptions the district court judge or a Federal Circuit judge? It is to this question that we now turn.

\section{Claim Meaning and the Proper Allocation of Interpretive Authority}

In his well-known book, Imperfect Alternatives, ${ }^{279}$ Professor Neil Komesar stresses the need to engage in comparative institutional analysis because the ability of an institution to discharge a given task cannot be viewed in isolation. ${ }^{280}$ One of Professor Komesar's central insights is the application of public choice theory to legal process considerations. $^{281}$ In the context of the adjudicative process, he writes that a "troubling and important tradeoff between information and independence ... is that insulation separates judges from a great deal of information about the desires and needs of the public." ${ }^{282}$ In contrast, politicians are more accessible, and this access can "provide them with the most robust and dramatic information on the central question of desires and needs." ${ }^{283}$ At the same time, however, public choice theory suggests that political access can lead to a "severely distorted view of public needs." 284 Thus, the "tradeoff is between a political process that integrates far more information but with a more significant risk of bias and an adjudicative process that suppresses information but decreases distortions in its presentation." 285

In the context of claim interpretation, the institutional choice is whether the district court or the Federal Circuit should be the principal arbiter. Although in the end the "choice is always" between "imperfect alternatives, "286 the trial judge is better equipped to make a more informed decision on claim meaning. Most technological communities

\footnotetext{
279. Neil K. Komesar, Imperfect Alternatives: Choosing Institutions IN LAw, ECONOMICS, AND PUBLIC POLICY (1994).

280. See Edward L. Rubin, Institutional Analysis and the New Legal Process, 1995 Wis. L. REV. 463, 464 (reviewing NEIL K. KOMESAR, IMPERFECT Alternatives: Choosing Institutions in LAw, Economics, And Public Policy (1994)) ("[T]he real question is how a given institution performs in comparison with other institutions to which that same task might be assigned.").

281. See id. at 464-65.

282. KOMESAR, supra note 279 , at 141 .

283. Id.

284. Id.

285. Id.

286. Id. at 5 .
} 
have complex constituencies with competing interests in claim meaning. ${ }^{287}$ Therefore, the principal arbiter should be independent and not susceptible (or less susceptible) to the influence of these factional interests. In addition, background assumptions and industrial custom play an important role in discerning the meaning of claim language. Therefore, the principal arbiter must also be flexible and have access to the relevant technological information. In comparing the institutional competence of an appellate or a district court judge, both are sufficiently independent. However, a district court judge, as the finder of fact, is in a far better position to gather and evaluate factual and technological information. ${ }^{288}$

If the district court is the more competent institution to interpret claim meaning, the logic of deferential appellate review becomes apparent. Deference is based largely on functional considerations such as: (1) institutional competence; (2) the temporal dimension of an infringement analysis, particularly the Doctrine of Equivalents; and (3) early certainty and uniformity as engendered by application of the doctrine of issue preclusion.

\section{a. Institutional Competence}

It is axiomatic that the trial judge is closer to the action and, therefore, more intimate with the relevant industry's background assumptions than an appellate judge. ${ }^{289}$ Thus, deference seems

287. As many scholars have asserted, the inventive entity is no longer a sole inventor, but rather, an assortment of private firms, universities, and government agencies. See, e.g., Rycroft \& Kash, Innovation Policy, supra note 28, at 73-79; Rycroft \& KASH, THE COMPlexity CHALlenge, supra note 28; Walter W. Powell, Inter-Organizational Collaboration in the Biotechnology Industry, $152 \mathrm{~J}$. InSTITUTIONAL \& THEORETICAL ECON. 97 (1996); Walter W. Powell et al., Interorganizational Collaboration and the Locus of Innovation: Networks of Learning in Biotechnology, 41 ADMIN. SCI. Q. 116 (1996).

288. See Arti K. Rai, Intellectual Property Rights in Biotechnology: Addressing New Technology, 34 WAKE FOREST L. REV. 827, 837 (1999) (asserting that " $[\mathrm{t}]$ he mistakes made by the CAFC [i.e., Federal Circuit] stem in large part from institutional constraints. . . [including a lack of resources to] expand its decisionmaking capacity to keep pace with the expansion of technology.").

289. See, e.g., Maurice Rosenberg, Judicial Discretion of the Trial Court, Viewed From Above, 22 SYR. L. REV. 635, 663 (1971) (writing that it is not that the trial court judge "knows more than his loftier brothers; rather, he sees more and senses more"). Professor Rosenberg goes on to write:

In the dialogue between the appellate judges and the trial judge, the former often seem to be saying: "You were there. We do not think we would have done what you did, but we were not present 
particularly appropriate when there are competing assumptions or customs in a scientific community because the trial judge is institutionally positioned to examine the extrinsic context, determine credibility, and then choose (i.e., interpret) between or among the proffered meanings. ${ }^{290}$ In a situation where there are competing claim meanings, a district court judge (particularly when aided by an independent court-appointed expert), armed with extrinsic evidence, will more likely than an appellate judge arrive at a meaning of a claim term that is consistent with the technologic community's understanding.

The necessity of extrinsic evidence to the district court judge has led several prominent district court judges to express frustration with and bewilderment over the Federal Circuit's de novo standard of review and its limitations on extrinsic evidence. ${ }^{291}$ For example, Judge

\footnotetext{
and we may be unaware of significant matters, for the record does not adequately convey to us all that went on at the trial.

Id. Therefore, we defer to you."

290. See Salve Regina Coll. v. Russell, 499 U.S. 225, 233 (1991) (stating that an appellate court should accord deference to the district court "when it appears that the district court is 'better positioned' than the appellate court to decide the issue in question or that probing appellate scrutiny will not contribute to the clarity of legal doctrine"); First Options of Chicago, Inc. v. Kaplan, 514 U.S. 938, 948 (1995) ("[T]he reviewing attitude that a court of appeals takes toward a district court decision should depend upon 'the respective institutional advantages of trial and appellate courts.'”) (quoting Salve Regina). In his Cybor dissent, Judge Rader elaborated on the district court's institutional advantage:

Trial judges can spend hundreds of hours reading and rereading all kinds of source material, receiving tutorials on technology from leading scientists, formally questioning technical experts and testing their understanding against that of various experts, examining on site the operation of the principles of the claimed invention, and deliberating over the meaning of the claim language. ...

An appellate court has none of these advantages. It cannot depart from the record of the trial proceedings. To properly marshal its resources, the appellate bench must enforce strict time and page limits in oral and written presentations. Moreover, a sterile written record can never convey all the nuances and intangibles of the decisional process.

Cybor Corp. v. FAS Techs., Inc., 138 F.3d 1448, 1477-78 (Fed. Cir. 1998) (Rader, J., dissenting).

291. See, e.g., Judge Dee Benson, Resources for Adjudicating Complex Technology Issues, in 4 Globalization of Intellectual Property IN THE 21St Century 43, 47, 49 (1998). Judge Benson wrote:

[K] eep this in mind about a typical district judge: he or she has something in the neighborhood of 400 to 700 cases. I have about
} 
McKelvie of the District Court in Delaware, in a footnote of an opinion that is worth quoting in full, candidly wrote:

As I understand Markman [ $I]$, because claim construction presents a purely legal question, trial judges must ignore all non-transcribable courtroom occurrences .... When two experts testify differently as to the meaning of a technical term, and the court embraces the view of one, the other, or neither while construing a patent claim as a matter of law, the court has engaged in weighing evidence and making credibility determinations. If those possessed of a higher commission wish to rely on a cold written record and engage in de novo review of all claim constructions, that is their privilege. But when the Federal Circuit Court of Appeals states that the trial court does not do something that the trial court does and must do to perform the judicial function, the court knowingly enters the land of sophistry and fiction .... As a consequence, bound by slavish adherence to the fiction that a judge does not make credibility determinations when confronted with testimonial extrinsic evidence en route to pronouncing the "true" meaning of a patent claim, this opinion has been crafted in a manner that leaves the reader, and the reviewing court, uninformed as to the credibility

450 cases presently. About 75 or 80 of those are criminal cases which demand priority. Of the remaining 300 or 400 or 500 cases, all of which demand attention, a small percentage involves intellectual property. I receive more trade dress cases than patent cases. . . .

. . I I would offer ten quick rules to any practitioner in the United States. . . .

Number six, I would choose good experts. . . . Not experts who are patent lawyers and are just an added, concealed addition to your legal staff, but some people who can actually help explain that model or diagram that you've placed before the judge. I think a good teacher in an expert is very important, especially for this person who will be interpreting as a matter of law, the claims in the patent involved.

Id. In 1999, less than one percent of all cases commenced in federal district court were patent cases $(2,318$ out of 260,271). See Judicial Business of the United States Courts, Table C-2A, Administrative Office of the United States Courts (1999). 


\begin{abstract}
assessments which, as always, are necessary precursors to the acceptance or rejection of testimonial evidence from competing experts. In fairness to all, those assessments unavoidably have been made in evaluating all testimony and in connection with exhibits relating to claim construction. ${ }^{292}$
\end{abstract}

In short, "a careful consideration of the institutional advantages of the district court would counsel deference." 293

\title{
b. The Temporal Dimension of the Doctrine of Equivalents
}

Any theory of claim interpretation must be sensitive to the common law Doctrine of Equivalents ("DOE"). In the 1850s and certainly towards the end of the nineteenth century, there was a push to require patent applicants to claim their inventions with more particularity. ${ }^{294}$ But a call for precision was also an invitation for circumvention, thereby potentially transforming "the protection of the patent grant into a hollow and useless thing." 295 The equitable response was the Doctrine of Equivalents, which allowed a finding of infringement even if the claim

292. Lucas Aerospace Ltd. v. Unison Indus. L.P., 890 F. Supp. 329, 333 n.7; see also In re Mahurkar Double Lumen Hemodialysis Catheter Patent Litig., 831 F. Supp. 1354, 1359 (Easterbrook, J.) ("[J]udges should not pretend that all nominally 'legal' issues may be resolved without reference to facts."); Cybor, 138 F.3d at 1480 (Newman, J., additional views) ("By continuing the fiction that there are no facts to be found in claim interpretation, we confound rather than ease the litigation process."). In another opinion, Judge McKelvie wrote:

In Markman, the Federal Circuit stated, in no uncertain terms, that it would have the final say as to the meaning of words in a claim of a patent, according no deference to decisions by the various United States District Court Judges. That is, in spite of a trial judge's ruling on the meaning of disputed words in a claim, should a three-judge panel of the Federal Circuit disagree, the entire case could be remanded for retrial on different claims.

Elf Atochem N. Am., Inc. v. Libbey-Owens-Ford Co., 894 F. Supp. 844, 857 (D. Del. 1995) (citation omitted).

293. Cybor, 138 F.3d at 1478 (Rader, J., dissenting). Indeed, the Supreme Court has recognized that there are "circumstances in which Congress or this Court has articulated a standard of deference for appellate review of district-court determinations [to] reflect an accommodation of the respective institutional advantages of trial and appellate courts." Salve Regina, 499 U.S. at 233.

294. See supra note 50.

295. Graver Tank \& Mfg. Co. v. Linde Air Prods. Co., 339 U.S. 605, 607 (1949). 
in issue did not literally read on the accused product. ${ }^{296}$ In many ways, the doctrine was a reaction to the inherent limitations of language.

The DOE has come under attack in recent years by commentators $^{297}$ and the Federal Circuit, particularly the hypertextualists. Beginning with Judge Lourie's opinion in London v. Carson Pirie Scott \& Co. ${ }^{298}$ the hypertextualists have sought to eliminate or greatly circumscribe the application of the DOE because the doctrine, in requiring the judge to look beyond the claim language and the written text, frustrates the notice function of the patent claim.

The central question under the DOE is: To what extent can a patentee capture a technological advance that may have been stimulated or influenced by the patent's disclosure, yet does not fit literally within the patent's claim? This question implies the existence of a postissuance temporal dimension to a DOE analysis. Indeed, as the Supreme Court recently noted, "the proper time for evaluating equivalency... is at the time of infringement, not at the time the patent was issued." ${ }^{299}$ The DOE is applied at the time of infringement because of the cumulative and unforeseeable nature of complex and ramified technologies, whereby one inventor opens a door for a subsequent inventor, a door which was perhaps not foreseeable at the time the first inventor filed for a patent, yet was eventually made possible because of the first inventor's patent disclosure. ${ }^{300}$

296. By "read on" I mean that each limitation of the claim at issue is found in the accused device. See Amhil Enters. Ltd. v. Wawa, Inc., 81 F.3d 1554, 1562 (Fed. Cir. 1996) ("Literal infringement of a claim exists when every limitation recited in the claim is found in the accused device, i.e., when the properly construed claim reads on the accused device exactly.").

297. See, e.g., Paul M. Janicke, Heat of Passion: What Really Happened in Graver Tank, 24 Am. Intell. Prop. L. Ass'N Q. J. 1, 152 (1996) (“All things considered, it is time to eliminate [the doctrine of equivalents]. Conceived in fairness, it now does more mischief than it achieves benefit. The reissue sections of the patent statute should be amended to allow broadened reissue at any time.").

298. 946 F.2d 1534 (Fed. Cir. 1991).

299. Warner-Jenkinson Co. v. Hilton Davis Chem. Co., 520 U.S. 17, 19 (1997) (emphasis added).

300. See Pennwalt Corp. v. Durand-Wayland, Inc., 833 F.2d 931, 941 n.4 (Fed. Cir. 1987) (en banc) ("It is clear that an equivalent can be found in technology known at the time of the invention, as well as in subsequently developed technology."). In Chiuminatta Concrete Concepts, Inc. v. Cardinal Industries, 145 F.3d 1303, 1310 (Fed. Cir. 1998), the court stated:

The doctrine of equivalents is necessary because one cannot predict the future. Due to technological advances, a variant of an invention may be developed after the patent is granted, and that variant may constitute so insubstantial a change from what is 
It would simply be too burdensome and would unduly limit the scope of protection to require a patent applicant to disclose every possible equivalent in the patent application. ${ }^{301}$ Because equivalents of the claimed invention are not limited to those disclosed in the patent document, a judge must not only parse the text of the patent, but must also determine the technological advance of the alleged infringer and the extent to which the alleged infringer benefitted from the patentee's inventive contribution - a contribution that is not explicitly captured by the patent's text. ${ }^{302}$ In other words, under an equivalency analysis, a judge must ascertain the inventive contributions of both the patentee and the alleged infringer. To fully appreciate the patent's claim scope when determining equivalents, a judge must look beyond the patent's text and substantively examine the extrinsic context of both the patented invention and the allegedly infringing invention. ${ }^{303}$ As the Supreme Court stated in Graver Tank \& Manufacturing. Co. v. Linde Air Products Co..$^{304}$

Like any other issue of fact, final determination [of equivalency] requires a balancing of credibility, persuasiveness and weight of evidence. It is to be decided by the trial court and that court's decision, under general principles of appellate review, should not be disturbed unless clearly erroneous. Particularly is this so in a field where so much depends upon

claimed in the patent that it should be held to be an infringement. Such a variant, based on after-developed technology, could not have been disclosed in the patent.

301. See S.R.I. Int'1 v. Matsushita Elec. Corp., 775 F.2d 1107, 1121 (Fed. Cir. 1985) (en banc) (plurality opinion) ("The law does not require the impossible. Hence, it does not require that an applicant describe in his specification every conceivable and possible future embodiment of his invention."); Texas Instruments, Inc. v. United States Int'1 Trade Comm'n, 805 F.2d 1558, 1563 (Fed. Cir. 1986) ("It is not required that those skilled in the art knew, at the time the patent application was filed, of the asserted equivalent means of performing the claimed functions.").

302. Although this approach is reminiscent of Professor Eskridge's "dynamic statutory interpretation," see generally, ESKRIDGE, supra note 1, in claim interpretation, as opposed to statutory interpretation, a judge is focused on a specific technological community that shares a common language. To the extent there are choices within that community, the judge is nonetheless cabined much more so than he would be if interpreting a statute.

303. See IMS Tech., Inc. v. Haas Automation, Inc., 206 F.3d 1422, 1435 (Fed. Cir. 2000) (asserting that "the context of the invention should be considered when performing" an equivalence analysis).

304. 399 U.S. 605 (1949). 
familiarity with specific scientific problems and principles not usually contained in the general storehouse of knowledge and experience. ${ }^{305}$

Hypertextualism, with its emphasis on textual fidelity and de novo review, may unduly limit the scope of patent protection and, therefore, have a negative effect on patent law's incentive dynamic. On the other hand, the linguistic terrain outside the claim can be slick, and one must be wary of migratory proprietary boundaries that can lead to uncertainty. A pragmatic textualist approach to claim interpretation, with its focus on internal coherence, industry custom and consequentialism is arguably best suited to balance these competing considerations. The use of pragmatism is particularly important in this regard. As Judge Posner, in the context of statutory interpretation, states:

[Pragmatist] judges use consequences to guide their decisions, always bearing in mind that the relevant consequences include systemic ones such as the risk of debasing the currency of statutory language. . . . ... The relevant consequences to the pragmatists are long run as well as short run, systemic as well as individual, the importance of stability and predictability as well as of justice to the individual parties, the importance of maintaining language as a reliable method of communication as well as of interpreting statutes and constitutional provisions flexibly in order to make them speak intelligently to circumstances not envisaged by their drafters. ${ }^{306}$

There is another point that I wish to address, and that is the interplay between prosecution history estoppeland the application of the DOE. What I have asserted in this article is that industry custom and the linguistic practices within an industry are as much a part of the public record as the patent document, including the latter's claims, written description, and prosecution history. However, there are certain forms of knowledge pertaining to a patent that are simply unknowable from a third-party competitor's perspective. For example, although when a patent applicant amends his claims during the prosecution of the patent, the reason for the amendment (e.g., to avoid prior art) is

305. Id. at 609-10.

306. POSNER, supra note 1 , at 400-01. 
generally discernable from the prosecution history, there are occasions when the reason is undiscoverable. In this situation (i.e., when the reason for the amendment is unknown), the Federal Circuit, in Sextant Avionique, S.A. v. Analog Devices, Inc. ${ }^{307}$ a hypertextualist opinion, held that with respect to the amended claim language, the applicant is barred entirely from utilizing the DOE. ${ }^{308}$ In a more recent decision, the Federal Circuit sitting en banc has gone one step further. In Festo Corp. v. Shoketsu Kinzoku Kogyo Kabushiki Co. ${ }^{309}$ the court, in the name of certainty, held that "when a claim amendment creates prosecution history estoppel with regard to a claim element, there is no range of equivalents available for the amended claim element." ${ }^{\text {"310 }}$ That is, even if the reason for the amendment is known, "[a]pplication of the doctrine of equivalents to the claim element is completely barred." ${ }^{\prime 11}$ These decisions underscore what little emphasis (or faith) the hypertextualists place on extrinsic context.

I posit that, from a policy perspective, the reason for the existence of an amendment is irrelevant to whether or not the DOE can be asserted in the first instance. ${ }^{312}$ Rather, an amendment is important only

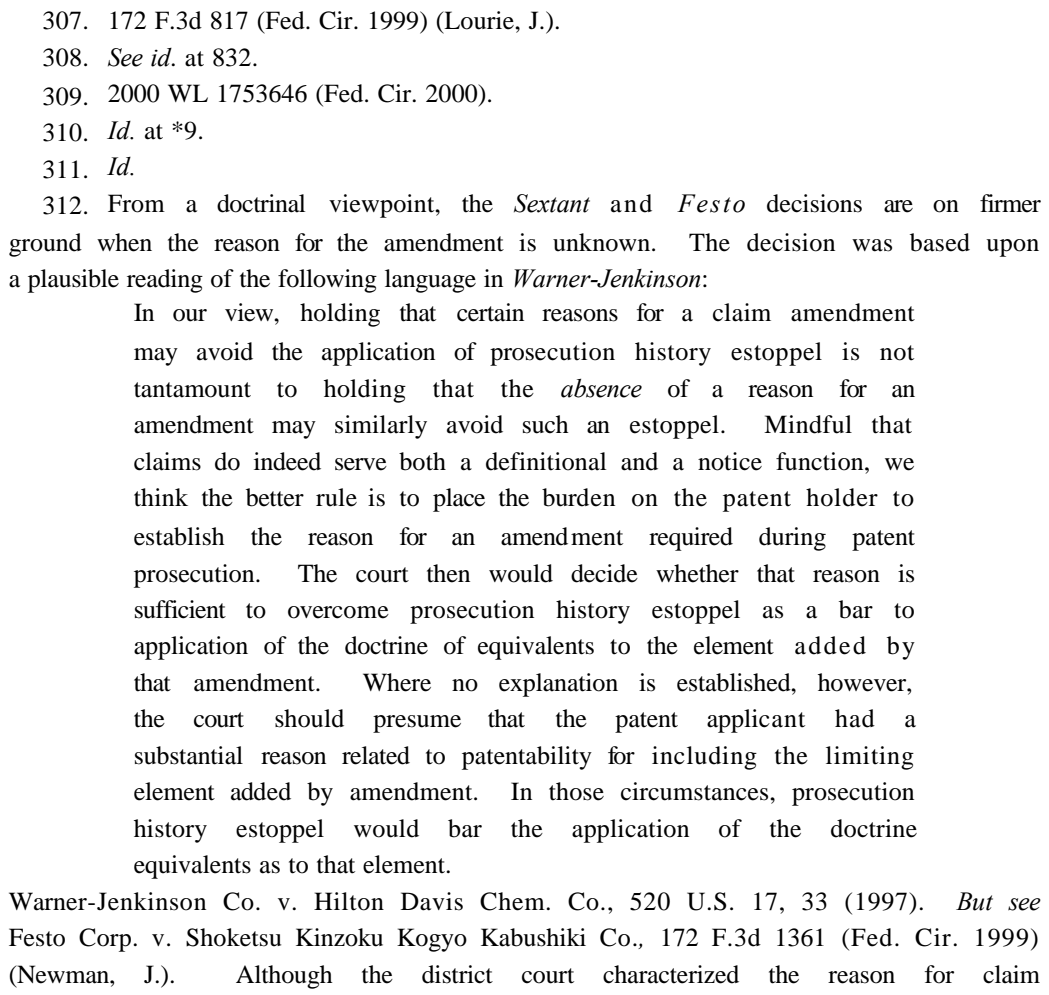


for purposes of determining the scope of equivalence, if any - that is, the extent to which the patentee can extend his equivalence claim to capture allegedly infringing products. Let's look at a simple hypothetical:

Inventor originally claims a composition of matter comprising $\mathrm{X}$ and $\mathrm{Y}$. During prosecution, she amends her claim and substitutes $\mathrm{Q}$ for $\mathrm{X}$. The patent issues. A few years after Inventor's patent issues, it becomes known in the industry that with respect to the subject matter being claimed, $\mathrm{Z}$ is equivalent to $\mathrm{Q}$. Competitor 1 begins to make $\mathrm{X}$ and $\mathrm{Y}$. Competitor 2 begins to make $\mathrm{Z}$ and $\mathrm{Y}$.

Certainly, the doctrine of prosecution history estoppel would prevent Inventor from recapturing X. Festo, however, would bar Inventor from asserting infringement under the DOE against Competitor 2 even though Inventor only surrendered X, not Z. But this should be a scope issue, not a question of whether DOE can be asserted. In this situation, Inventor should be allowed to make a DOE claim, but its scope would not cover $\mathrm{X}$. Given the knowledge in the industry that $\mathrm{Z}$ is equivalent to $\mathrm{Q}$, why shouldn't Inventor be entitled to assert the DOE against Competitor 2? For the hypertextualists, surrendering an inch is equivalent to total surrender.

\section{c. Early Certainty, Uniformity, and Issue Preclusion}

The pragmatic textualists on the Federal Circuit have argued that deference is also appropriate because making it more difficult to reverse a trial judge's claim interpretation will most likely lead to greater certainty earlier in the litigation process and, therefore, induce settlement negotiations. ${ }^{313}$ Accordingly, the pragmatic textualists assert

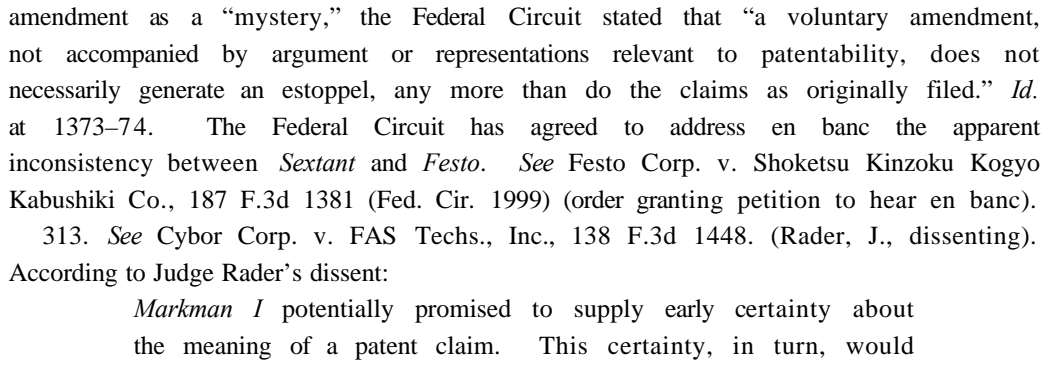


that it is disingenuous to suggest that de novo review of the trial court's claim interpretation will lead to certainty and to the "true" meaning of the claim. Indeed, if anything, characterizing claim interpretation as a question of law will have the opposite effect. ${ }^{314}$

In support of de novo review and exclusion of extrinsic evidence, the hypertextualists cite Justice Souter's language in Markman II regarding the need for uniformity in patent law and the Federal Circuit's role in promoting uniformity. ${ }^{315}$ The argument is that in the absence of

prompt early settlement of many, if not most, patent suits. Once the parties know the meaning of the claims, they can predict with some reliability the likelihood of a favorable judgment, factor in the economics of the infringement, and arrive at a settlement to save the costs of litigation.

Id. at 1475 .

314. Judge Rader further noted:

Instead, the current Markman I regime means that the trial court's early claim interpretation provides no early certainty at all, but only opens the bidding. The meaning of a claim is not certain (and the parties are not prepared to settle) until nearly the last step in the process - decision by the . . Federal Circuit. To get a certain claim interpretation, parties must go past the district court's Markman $I$ proceeding, past the entirety of discovery, past the entire trial on the merits, past post trial motions, past briefing and argument to the Federal Circuit - indeed past every step in the entire course of federal litigation, except Supreme Court review. In implementation, a de novo review of claim interpretation has postponed the point of certainty to the end of the litigation process, at which point, of course, every outcome is certain anyway.

Id. at 1476; see also Kimberly M. Ruch-Alegant, Note, Markman: In Light of De Novo Review, Parties to Patent Infringement Litigation Should Consider the ADR Option, 16 TEMP. ENVTL. L. \& TECH. J. 307, 308 (1998) ("De novo review of claim interpretation by the appellate court has the practical effect of forcing the parties to completely relitigate the issue of patent infringement on appeal.") According to one practitioner:

$[\mathrm{O}]$ ne would expect that shifting the duty of claim construction from the jury to the judge would result in more instances of proper claim constructions at the trial court level and thus fewer reversals by the Federal Circuit. Thus far, however, the Markman decision has done little to remove the cloud of uncertainty surrounding claim construction.

Holmes J. Hawkins, III, Claim Interpretation in a Post-Markman Environment, in Patent Litigation, 681, 683-84 (PLI Patents, Copyrights, Trademarks, and Literary Property Course Handbook Series No. 572, 1999).

315. See Markman v. Westview Instruments, Inc., 517 U.S. 370. According to Justice Souter:

[W]hereas issue preclusion could not be asserted against new and 
issue preclusion, the eradication of the jury from claim interpretation would allow a judge, armed with stare decisis, to construe the claim language in question once and for all. ${ }^{316}$ This argument is legitimate, but it says nothing about the allocation of interpretive authority between the appellate tribunal and the trial court. ${ }^{317}$ Indeed, as I will explain below, there is little reason to doubt that vesting the district court judge with principal interpretive authority would lead to the type of uniformity discussed in Markman II. The key to promoting uniformity and predictability was eliminating the jury from claim interpretation.

Furthermore, we must keep in mind that the creation of the Federal Circuit was prompted by a post-issuance phenomenon that pertained to the disparities extant in the adjudication of patent disputes by the regional circuit courts. ${ }^{318}$ Prior to the creation of the court, it was not uncommon for an issued patent to have been declared invalid in one circuit court, but valid in another. ${ }^{319}$ Thus, it is no doubt true that the policies behind the creation of the Federal Circuit were to instill certainty and uniformity into the patent laws and to prevent forum shopping by patentees and alleged infringers. ${ }^{320}$ However, these policy objectives do not necessarily translate into de novo review and, for all practical purposes, the exclusion of extrinsic evidence. Certainty and

\footnotetext{
independent infringement defendants even within a given jurisdiction, treating interpretive issues as purely legal will promote (though it will not guarantee) intrajurisdictional certainty through the application of stare decisis on those questions not yet subject to interjurisdictional uniformity under the authority of the single appeals court.

Id. at 391 .

316. See id.

317. See Cybor, 138 F.3d at 1480 (Newman, J., additional views) (asserting that the Supreme Court's "affirmation [in Markman II] that claim interpretation 'is exclusively within the province of the court' did not shut out the trial judge with the jury" (citation omitted)).

318. Before the creation of the Federal Circuit in 1982, a patent case was appealed from federal district court to the regional circuit court of appeals.

319. See H.R. REP. No. 97-312, at 20-21, 22 (1981) ("[S]ome circuit courts are regarded as 'pro-patent' and others 'anti-patent,' and much time and money is expended in 'shopping' for a favorable venue. . . . [Furthermore,] the validity of a patent is too dependent upon geography (i.e., the accident of judicial venue) to make effective business planning possible.").

320. See id. at 22 ("A single court of appeals for patent cases will promote certainty where it is lacking to a significant degree and will reduce, if not eliminate, the forumshopping that now occurs."); see also S. REP. NO. 97-275, at 5 (1981) ("The creation of the Court of Appeals for the Federal Circuit will produce desirable uniformity in this area of the law. Such uniformity will reduce the forum-shopping that is common to patent litigation.”).
} 
uniformity will not be threatened - indeed, they will be enhanced - if the court were to apply a more deferential standard of review and were to relax its restrictions on the admissibility of extrinsic evidence. In this regard, the Federal Circuit's role in promoting uniformity and certainty in our patent system is fulfilled simply by its exercising exclusive appellate jurisdiction. If we accept that the district court judge, because of his institutional position and all of its concomitant benefits, should be the principal arbiter of claim meaning, then a deferential standard of review by a singular appellate court would not diminish the realization of certainty and uniformity. By simply reviewing the case and reaching a decision, the Federal Circuit has provided the claim language in question with a uniform meaning - regardless of the standard of review.

There is one scenario that is frequently cited by those who support de novo review. This scenario envisions the same patent claim language being litigated simultaneously in two district courts. It is plausible in such a situation that the two district court judges will arrive at dissimilar claim interpretations based upon their respective understandings of the extrinsic evidence. A more deferential standard of review, the argument goes, may lead to affirming two divergent interpretations, particularly where there is disagreement within the technological community as to the meaning of the claim language in question.

This scenario, however, overlooks the application of the doctrine of issue preclusion or collateral estoppel as illustrated by TM Patents L.P. v. International Business Machines Corp. ${ }^{321}$ There, the patentee, TM Patents, brought a patent infringement suit against IBM in the Southern District of New York alleging that IBM infringed TM's '979, '342, and ' 773 patents. ${ }^{322}$ Judge McMahon held a Markman hearing ${ }^{323}$ to construe the relevant claim language in the three patents. A few years before the New York litigation, however, TM had sued EMC Corporation in a separate patent infringement proceeding in the District

321. 72 F. Supp. 2d 370 (S.D.N.Y. 1999); see also Abbott Labs. v. Dey, L.P., 110 F. Supp. 2d 667, 669-73 (N.D.Ill. 2000) (following TM Patents v. IBM). But see Graco Children's Prods., Inc. v. Regalo Int'1, LLC, 77 F. Supp 2d. 660, 665 (E.D. Pa. 1999) (declining to follow TM Patents v. IBM). For a discussion comparing TM Patents $v$. $I B M$ and Graco, see Craig A. Nard, Process Considerations in the Age of Markman and Mantras, 2001 ILL. L. REV. (forthcoming 2001).

322. See TM Patents v. IBM, 72 F. Supp. 2d at 375.

323. A Markman hearing is a proceeding whereby the district court judge hears evidence on claim construction, and, thereafter, construes the claims in issue before a trial on the merits commences. See, e.g., id. at 375. 
Court of Massachusetts. ${ }^{324}$ In the Massachusetts case, Judge William Young had also held a Markman hearing and had construed some of the same claim language of the ' 342 patent that TM was asserting in the New York litigation. ${ }^{325}$ As a result, IBM argued that TM was collaterally estopped from relitigating the claim language that Judge Young had construed in the Massachusetts litigation. ${ }^{326}$ Although recognizing that no case had yet applied the doctrine of collateral estoppel to bar relitigation of claim construction, Judge McMahon agreed with IBM, stating that application of collateral estoppel "seems self-evident.",327

Judge McMahon began her analysis by reciting the four elements ${ }^{328}$ that must be met for collateral estoppel to apply. Of the four criteria, the parties agreed that two were satisfied - namely, "the issues raised in both proceedings must be identical" and "the party to be estopped must have had a full and fair opportunity to litigate the issues in that prior proceeding." 329 The disagreement centered around the "finality" of the prior judgment. ${ }^{330} \mathrm{TM}$ strenuously asserted that the Massachusetts claim construction was not preclusive because the case settled during trial and Judge Young's "rulings were not sufficiently 'final." ",331 Judge McMahon was not persuaded:

Unfortunately for TM, that is not the law of this Circuit (or any other, for that matter). Since Judge Friendly's seminal opinion in Lummus Co. $v$. Commonwealth Oil Ref. Co., it has been settled that a judgment that is not "final" in the sense of 28 U.S.C. $\S 1291$ can nonetheless be considered "final" in the sense of precluding further litigation of issues that

324. See TM Patents L.P. v. EMC Corp., No. 98-10206 (D. Mass. Jan. 27, 1999).

325. See id.

326. See TM Patents v. IBM, 72 F. Supp. $2 \mathrm{~d}$ at 375.

327. Id. at 376 ("While this raises an issue of first impression, I conclude that Judge Young's resolution of the meaning of certain disputed patent terms following a Markman hearing, at which TM had a full and fair opportunity to litigate the meaning of those terms, is binding on the Plaintiffs in this action.").

328. See id. at 375 (The four elements are: (1) the issues raised in both proceedings must be identical; (2) the relevant issues must have actually been litigated and decided in the prior proceeding; (3) the party to be estopped must have had a full and fair opportunity to litigate the issues in that prior proceeding; and (4) resolution of the issues must have been necessary to support a valid and final judgment on the merits).

329. Id.

330. See id. (Judge McMahon collapsed elements two and four because "in this particular case, the fourth element (finality) subsumes the second (actually decided)."). 331. Id. 
were actually determined in such a judgment. ... As Judge Friendly observed, "Finality' in the context here relevant may mean little more than that the litigation of a particular issue has reached such a stage that a court sees no really good reason for permitting it to be litigated again." ${ }^{332}$

What Judge McMahon found particularly persuasive was that "after Markman, claim construction became a separate legal issue." "333 As claim construction is a matter solely for the court in the post-Markman era, parties, much like TM in the Massachusetts and New York litigations, fully litigate claim meaning prior to trial. ${ }^{334}$ Therefore, once a judge construes the claims at the close of a Markman hearing, "[i]t is hard to see how much more 'final' a determination can be." ${ }^{335}$ Judge McMahon also noted that the Supreme Court, in affirming Markman I, emphasized the promotion of uniformity in claim meaning. ${ }^{336}$ For Judge McMahon,

After Markman, with its requirement that the Court construe the patent for the jury as a matter of law, it is inconceivable that a fully-litigated determination after a first Markman hearing would not be preclusive in subsequent actions involving the same disputed claims under the same patent. The nature of the Markman proceeding is such that finality is its aim. ${ }^{337}$

\footnotetext{
332. Id. at 375-76 (citation omitted).

333. Id. at 376 .

334. See id.

335. Id.

336. See id. at 377. The Federal Circuit, in Burke, Inc. v. Bruno Independent Living Aids, Inc., 183 F.3d 1334 (Fed. Cir. 1999), stressed the importance of uniformity and consistency in claim interpretation so much so that the court permitted a patentee to invoke what amounted to offensive issue preclusion against a new and independent defendant based upon an earlier non-precedential Federal Circuit opinion construing the "same claim of the same patent." Id. at 1338. Notably, Federal Circuit Rule 47.6(b) prohibits litigants from citing as precedent nonprecedential opinions; however, the rule does not "preclude assertion of issues of claim preclusion, issue preclusion, judicial estoppel, law of the case or the like based on" a nonprecedential opinion. According to the court, "the interest of consistency in the construction of patent claims would be ill served by interpreting Rule 47.6(b) to preclude consideration of a prior claim construction rendered as a matter of law by this court." Burke, 183 F.3d at 1337.

337. TM Patents v. IBM, 72 F. Supp. 2d at 377. The finality of a Markman ruling, according to Judge McMahon, also has implications for interlocutory appeals. According to Judge McMahon, "[S]o final is a Markman ruling that one could make a
} 
The point to be made here is that when two or more district court judges hold a Markman hearing and are willing to invoke collateral estoppel, the Federal Circuit's ability to promote uniformity and early certainty in claim meaning is no greater than that of a district court even if the district court judge applying collateral estoppel does not agree with his fellow judge's prior construction. ${ }^{338}$ In fact, de novo

strong case for routinely certifying an interlocutory appeal to the Federal Circuit . . . . I Id. at 377 n.1. However, the Federal Circuit has not been receptive to interlocutory appeals with respect to claim interpretation. As noted by Judge Newman:

Although the district courts have extended themselves, and socalled "Markman hearings" are common, this has not been accompanied by interlocutory review of the trial judge's claim interpretation. The Federal Circuit has thus far declined all such certified questions. . . . [thereby resulting in] two untoward consequences; first, the district court has had to conduct a perhaps unnecessary trial; and second, the eventual issuance of a new claim interpretation by the Federal Circuit, on appeal after final judgment, has sometimes required a second trial of the issue of infringement.

Cybor Corp. v. FAS Techs., Inc., 138 F.3d 1448, 1479 (Fed. Cir. 1998) (Newman, J., additional views). A third consequence has been for a party, faced with an unfavorable claim construction, to request that the district court judge enter an adverse judgment against them thereby prompting an immediate appeal to the Federal Circuit. See, e.g., Schering Corp. v. Amgen, Inc., 35 F. Supp. 2d 375, 376 (D. Del. 1999). In Schering, Judge Schwartz speculated that perhaps the reason the Federal Circuit disfavors interlocutory review of Markman decisions without a party initially conceding that it cannot succeed under the district court's claim interpretation is because of "the parties' intensity of preference for challenging adverse claim construction decisions." Id. at 377 n.2. Judge Schwartz continued:

[I]f a party must first consent to a final judgment of noninfringement, it will only challenge a claim construction decision when it concludes it cannot prove infringement under the claim interpretation. By denying interlocutory appeals, the Federal Circuit will only hear appeals from adverse claim construction decisions where the party concludes its case is irreparably harmed by the lower court's claim interpretation.

Id. However, the losing party on claim interpretation will most likely appeal after final judgment anyway - when district court and party resources have been expended, knowing full well that de novo review awaits. Law of the case will preclude a party losing after trial from appealing an interlocutory appeal that was accepted and decided by the Federal Circuit. Thereby significant judicial resources may be conserved, and the parties may be induced to settle before trial.

338. See TM Patents v. IBM, 72 F. Supp. $2 \mathrm{~d}$ at 379 ("I agree with just about everything Judge Young did when he construed the claims in the EMC action. Nonetheless, I have no doubt that collateral estoppel would apply against TM on the previously litigated claims even if I thought everything Judge Young decided was wrong."). 
review delays certainty, wastes trialcourt resources, and leads to costly appeals. Ironically, from a hypertextualist's vantage point, the characterization of claim construction as a question of law renders the determination a separate legal issue susceptible to collateral estoppel, thus enhancing the power of the district court judge. ${ }^{339}$

The application of collateral estoppel is also consistent with Markman II. Recall Justice Souter's language that "principles of issue preclusion . . o ordinarily foster uniformity." ${ }^{340}$ Thus, the Supreme Court envisioned that the Federal Circuit would promote uniformity in claim construction when collateral estoppel is unavailable - i.e., where a plaintiff, who received a favorable claim construction in a prior litigation, now brings an infringement suit against a new and independent defendant in a subsequent litigation. ${ }^{341}$ Thus, under my proposal, in the event the subsequent district court were to reach a different claim construction than the prior district court, it would be appropriate, in the name of uniformity, for the Federal Circuit to step in and choose which of the two interpretations should prevail. However, this exception is welcome not because the court is more competent to arrive at the "true" and "objective" meaning of the claim or because of some exaggerated notion of the notice function of patent claims; rather, it reflects a situation where the Federal Circuit is institutionally positioned to promote uniformity as the appellate patent court.

339. The argument throughout this article has been that de novo review and the exclusion of extrinsic evidence is improper when the issue before the court is claim meaning. I noted at the beginning of this Article that how courts interpret the patent code is a subject worthy of exploration. Although that exploration must wait for another day, it is worth noting here that in matters of statutory interpretation that do not relate directly to claim interpretation, de novo review is appropriate, and the Federal Circuit does play a significant role in promoting uniformity and predictability.

Statutes and claims are similar to a certain extent, but there are also important differences that suggest that with respect to statutes, the Federal Circuit should have principal interpretive authority. First, in interpreting statutes, the judge is the person of ordinary skill in the art. Second, the judge should understand how his interpretation affects industry. In his capacity, the Federal Circuit judge is better suited than the district judge. The Federal Circuit judge is exposed to the patent code more frequently, and therefore has developed a greater intimacy with the Patent Act, 35 U.S.C. (1994), and its role in research and development practices.

340. Markman v. Westview Instruments, Inc., 517 U.S. 370, 391 (1996).

341. See supra note 312. 
3. Choosing a Construction in the Face of Persistent Ambiguity: Canons of Claim Construction as Default Rules

Having concluded that the district court judge is better suited than his appellate colleagues to discern claim meaning and address ambiguity, the question becomes: How should a judge, faced with persistent ambiguity, choose between or among competing claim constructions? By "persistent" I mean that after consideration of the intrinsic and extrinsic evidence, the judge and his independent expert conclude that the claim language in question remains ambiguous.

One answer to this question is for the judge to apply canons of claim construction as a type of default rule. ${ }^{342}$ Indeed, there is a need for canons in claim interpretation, but their application should be limited to situations where the district court judge, after considering both the intrinsic and extrinsic evidence, determines that the claim is ambiguous. Importantly, the judge should determine exactly what type of ambiguity exists because the applicable canon will depend on the type of ambiguity.

If the claim is ambiguous in that it is subject to at least two reasonable constructions, the judge may be well-advised to invoke the doctrine of contra proferentem. This canon of construction posits that the court should adopt the construction that is less favorable to the party that drafted the language. ${ }^{343}$ This approach was adopted by the Federal Circuit in Athletic Alternatives, Inc. v. Prince Manufacturing, Inc., ${ }^{344}$ wherein the court, faced with claim language that was susceptible of two reasonable constructions, stated:

Where there is an equal choice between a broader and a narrower meaning of a claim, and there is an enabling disclosure that indicates that the applicant is at least entitled to a claim having the narrower meaning, . . [the] notice function of the

\footnotetext{
342. The courts throughout the years have formulated several canons of claim construction. See Donald S. Chisum, Chisum on PATENTS $\$$ 18.03[2] (2000) (discussing canons of claim construction). For purposes of this article, I am only interested in those canons that are invoked when the claim is deemed ambiguous.

343. For a discussion of the canon of contra proferentem in the context of government contract litigation, see C. Stanley Dees \& David A. Churchill, Government Contract Cases in the United States Court of Appeals for the Federal Circuit: 1996 in Review, 6 AM. U. L. REV. 1807, 1847 (1997).

344. 73 F.3d 1573 (Fed. Cir. 1996).
} 
claim ... [is] best served by adopting the narrower meaning. ${ }^{345}$

Although it invoked the canon of contra proferentem, the court did not label it as such. ${ }^{346}$ The application of contra proferentem is also consistent with the canon of claim construction that states that " $[w]$ hen claims are amenable to more than one construction, they should when reasonably possible be interpreted so as to preserve their validity."'347

Another option for a court confronted with claim ambiguity is to invalidate the claim for indefiniteness (i.e., the claim does not inform a person skilled in the art of the scope of the claim) under 35 U.S.C. $\S$ 112, II $2 .{ }^{348}$ This option is consistent with the notice function of the patent claim and, for that reason, was preferred by Judge Nies in Athletic Alternatives. ${ }^{349}$ However, invalidation should arguably be confined to claim language that is approaching unintelligibility. In this situation, the judge, arms thrown in the air, is saying, "I don't even have a choice between a narrower and broader construction."

Therefore, depending on the type of ambiguity present, the judge will have the option of either choosing the narrower construction or invalidating the claim. No matter the choice, the result is a sanction against the patentee, and, hopefully, a deterrent against poor claim drafting.

345. Id. at 1581

346. I criticized the court in Athletic Alternatives earlier in this article because extrinsic evidence was not considered prior to a finding of ambiguity. Nonetheless, assuming extrinsic evidence was considered and the court still found the claim ambiguous, application of contra proferentem would be proper.

347. Modine Mfg. Co. v. U.S. Int'1 Trade Comm'n, 75 F.3d 1545, 1557 (Fed. Cir.

1996). Of course, opting for the narrowing interpretation, while preserving the validity of the patent, may ultimately lead to a finding of noninfringement.

348. See, e.g., Morton Int'l, Inc. v. Cardinal Chem. Co., 5 F.3d 1464, 1470 (Fed. Cir. 1993) (holding patent claims invalid for indefiniteness); Amgen, Inc. v. Chugai Pharm. Co., 927 F.2d 1200, 1217-18 (Fed. Cir. 1991) (same).

349. In her concurring opinion, Judge Nies asserted the following:

I do not agree that the adoption of the narrower of two equally plausible interpretations somehow flows from the requirement of section 112 If 2 that the patentee must particularly point out and distinctly claim the subject matter which he regards as his invention. The majority analysis is illogical to me. Narrowness can not be equated with definiteness.

73 F.3d 1573, 1583 (Fed. Cir. 1996). 


\section{CONCLUSION}

There is a significant movement afoot at the Federal Circuit with respect to the proper treatment of extrinsic evidence. While what I have characterized as pragmatic textualism is gradually asserting itself within the confines of the court, hypertextualism remains the predominant interpretive approach to claim interpretation. I have argued that this overly formalistic and acontextual approach is misguided and self-contradictory. It proclaims to read claim language as a person of ordinary skill in the art would but, at the same time, eschews the use of extrinsic evidence, thus distancing itself from the very industry its ultimate interpretation will most directly affect. Hypertextualism's de novo review leads to uncertainty or, at best, dilatory certainty that impedes settlement negotiations and frustrates business planning. Most importantly, however, hypertextualism's disregard for the technological understanding of the private sector may very well adversely affect patent law's delicate incentive structure. Specifically, if courts substitute their own understanding of a claim for that of the technological community, the incentives to improve or design around a claim will evaporate because the claim itself does not have commonly understood boundaries.

Pragmatic textualism, on the other hand, is consistent with the patent code and contemporary legal and hermeneutic philosophy. The pragmatic textualist judge not only understands the importance of textual fidelity, but he also embraces technologic context and is sensitive to process considerations such as institutional competence. In short, the pragmatic textualist judge is self-aware, empirically inclined, and willing to look beyond the four corners of the patent text. 